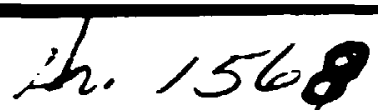

ORNL'ENGITM-8

Safety Analysis Report for Packaging:

The ORNL Lithium Hydroxide Fire and Impact Shield

J. H. Evans

R. E. Eversole

R. A. Just

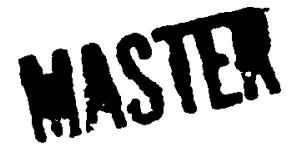

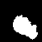

$a$

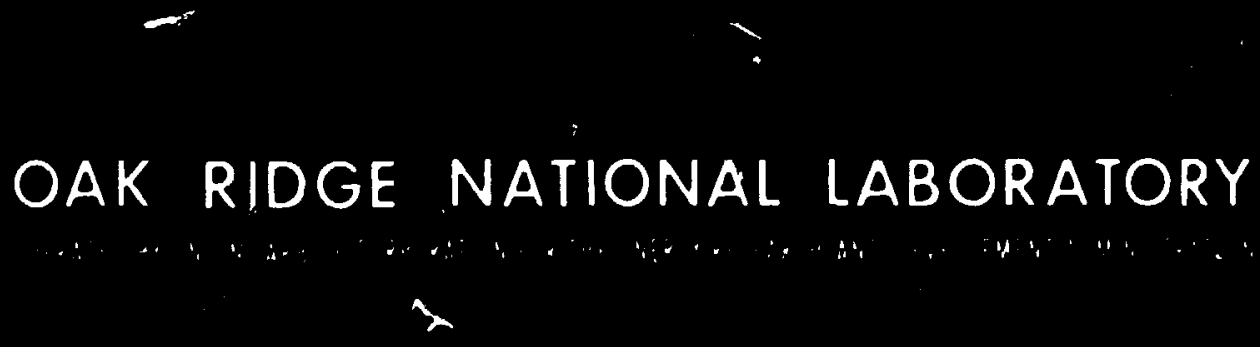




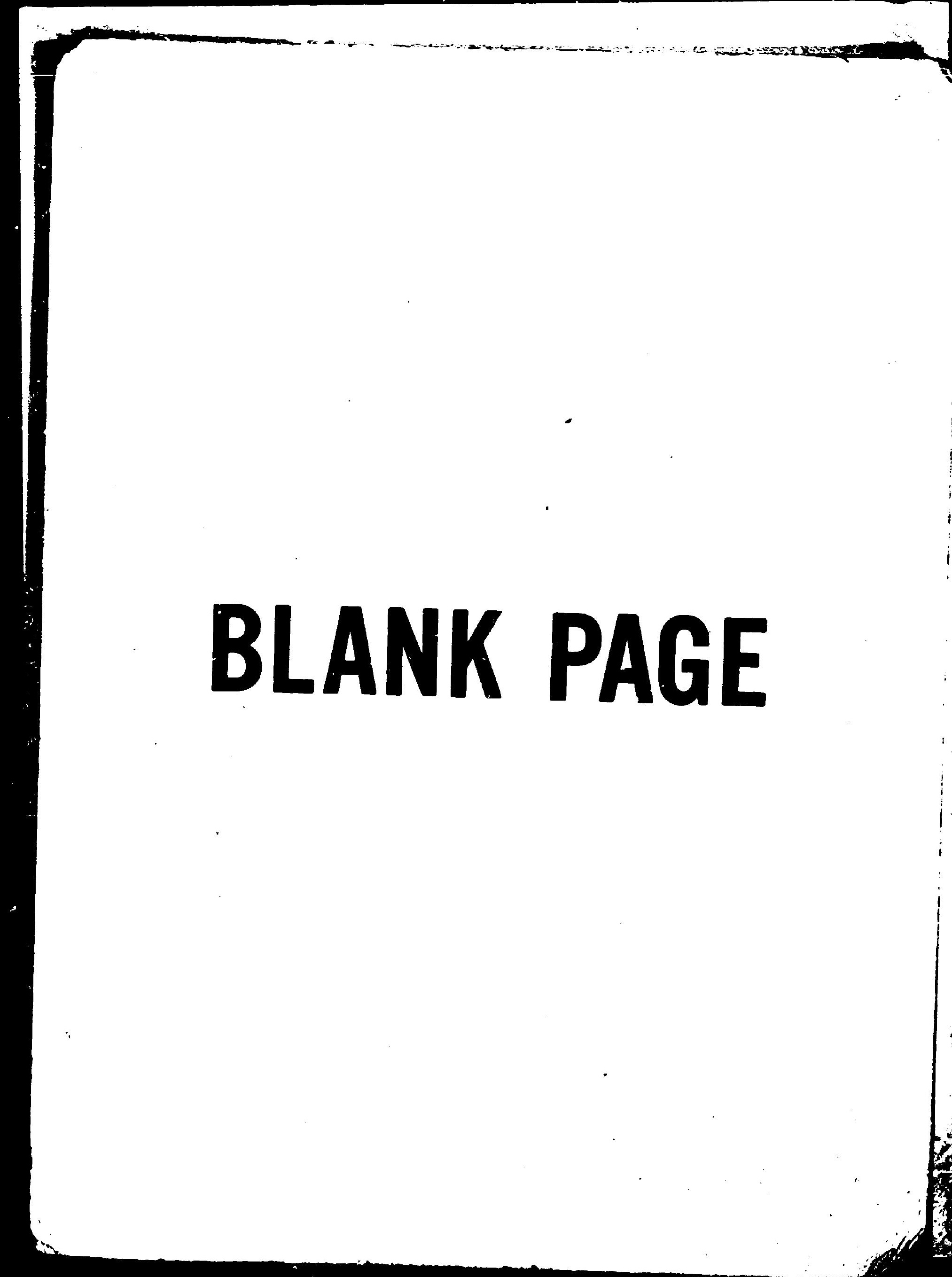


Printed in the United States of America. Available from

National Technical Information Service

U.S. Department of Commerce

5285 Port Royal Road, Springfield, Virginia 22161

Price: Printed Copy \$8.C0; Microfiche $\$ 3.00$

This repont was prepared es en eccount of work sponsored by an egency of the United States Government. Neither tho United States Government nor any agency thereof. nor any of their emf compractors. sutcontractors, or their employees, makes any warranty. expres. -implied. nor essumes any legal liability or responsibility for any third party's use or the resulis of such use of any information, apparatus, product or process dixclosed in this report, nor represents that its use by such third party would not infringe privetely swmed rights. 

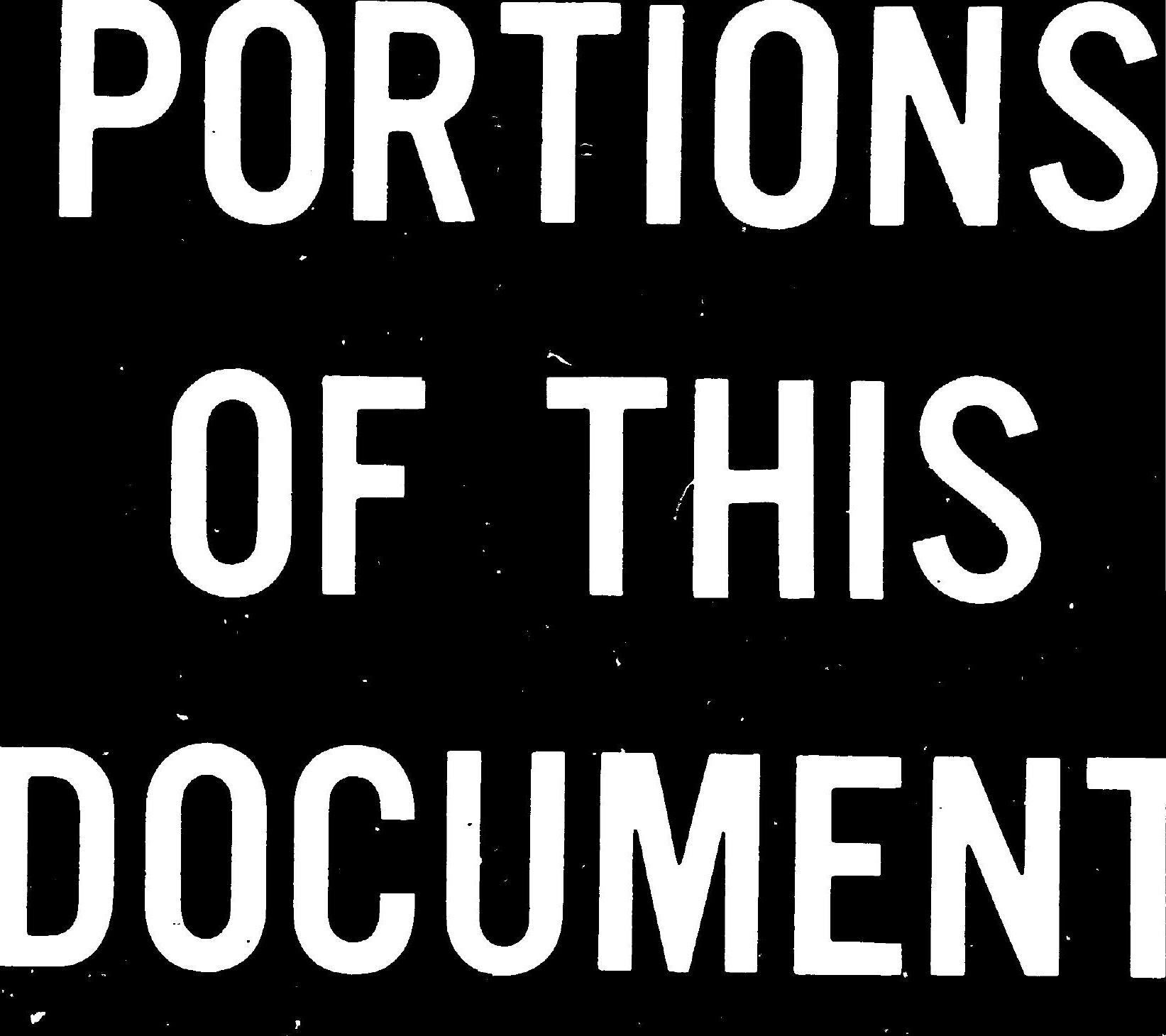

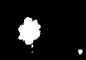
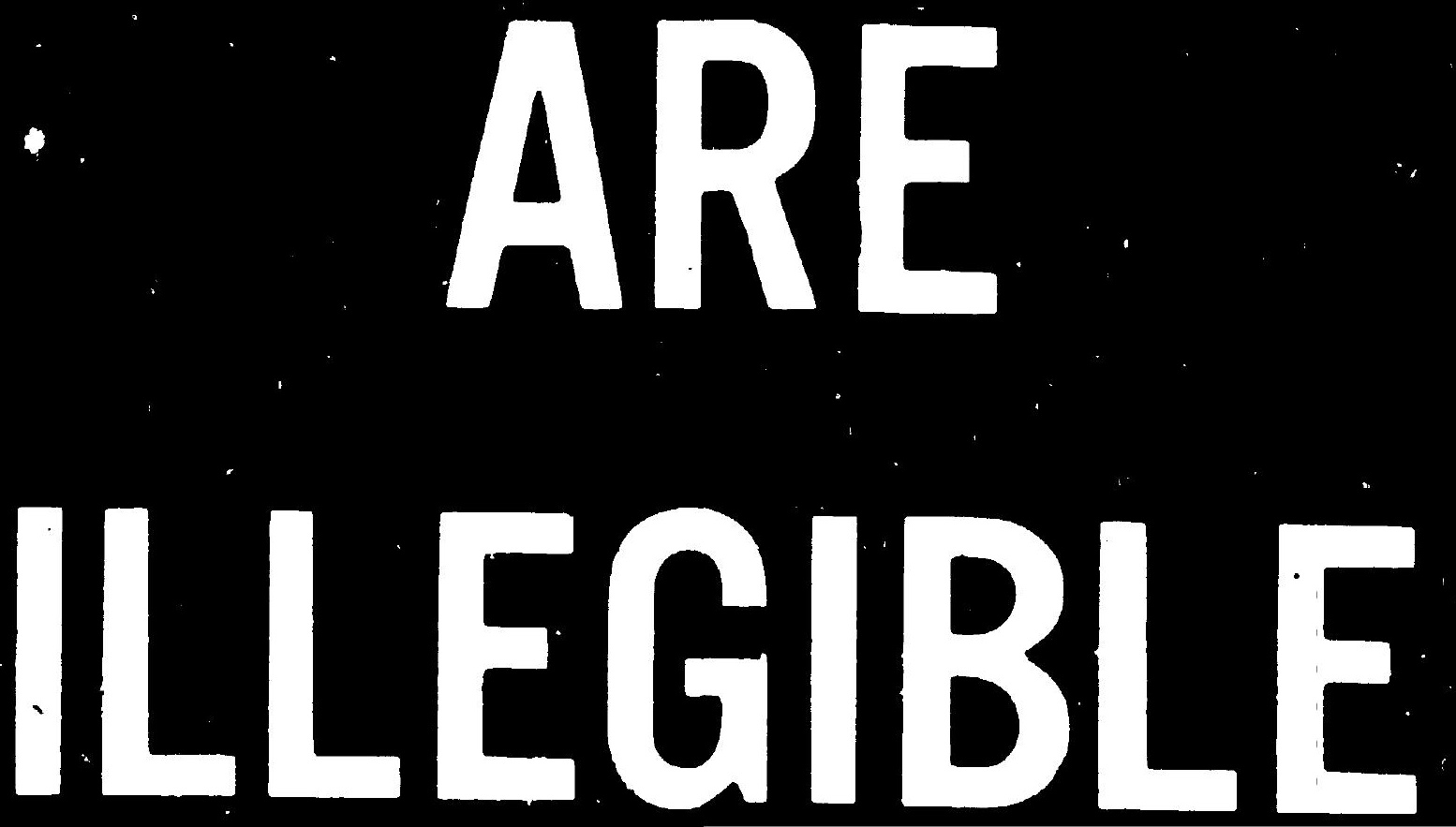


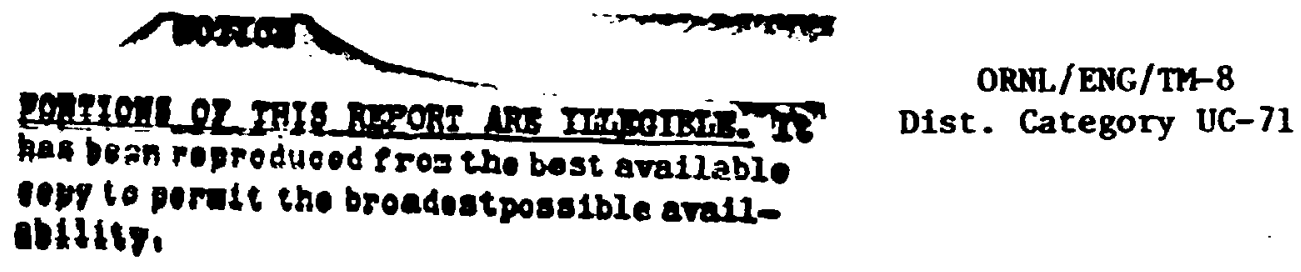

Contract No. W-7405-eng-26

ORN Ingineering

SAFETY GNALYSIS REPORT FOR PACKAGLIE: THE URNL

LITHIUM HYDROXIDE FIRE AND IMPACT SHIELD

J. H. Evans

R. E. Eversole

R. A. Just

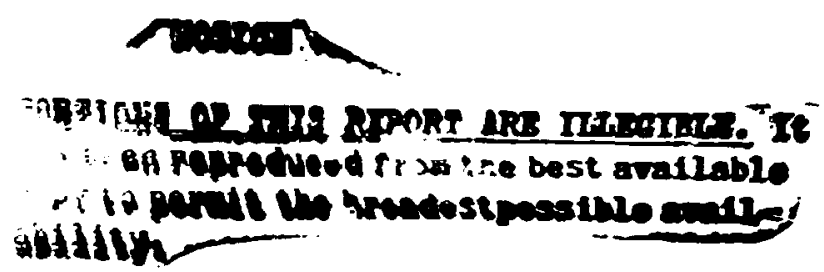

Date Published: November 1977

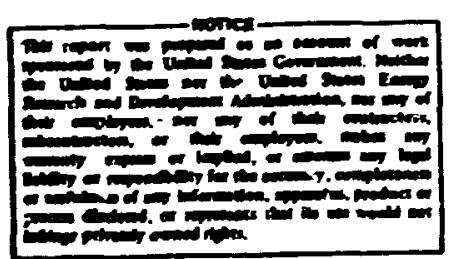

OAK RIDGE NATIONAL LABORATORY

Oak RIdge, Tennessee 37830

operated by

UNON CARHIDE CORPORATION

for the

DEPARTMENT OF ENERCY 
CONTENTS

Page

ACKNONLEDGMENTS . . . . . . . . . . . . . . . . ix

ABSTRACT ......................... 1

0. GENERAL INFORMATION ..................... 1

0.1 Introduction ................... 1

0.2 Package Description ............... 2

0.2.1 Contalnei $\mathrm{L}$ :scription ............ 2

0.2 .2 Operational Features . . . . . . . . . . 4

0.2 .3 Contents ............... . 4

0.2 .4 LiOH Cavities .............. 5

1. STRUCTURAL EVALUATION ................ 5

1.1 Mechanical Properties of Materials . . . . . . . 5

1.2 General Standards for All Packages ......... 5

1.2.1 Closure ................ 5

1.2.2 Cask-Lf fting Device ............ 6

1.2 .3 Lid-Lifting Device.............. 10

1.2 .4 Tie-D.rm Devices.............. . . 11

1.3 Standards for Type B and Large-Quantity Packaglng . . 17

1.3.1 Load Resistance . . . . . . . . . . . . 17

1.3.2 External Pressure . . . . . . . . . . . . 19

i. 4 Compliance with Standards for Normal Conditions

of Transport . . . . . . . . . . . . . . . . 21

1.4.1 Heat................... 21

1.4 .2 Cold .................. 22

1.4 .3 Fressure................. 22

1.4 .4 Vibrat1ons .............. . 24

1.4 .5 Water Spray .............. 24

1.4 .5 Free Jrop . . . . . . . . . . . . . . . 24

1.4 .7 Penetration . . . . . . . . . . . . 25

1.4.8 Compression . . . . . . . . . . . . . 25

1.5 Compliance with Standards for Hypothetical

Accident Conditilins . . . . . . . . . . . . . 26

1.5.1 iree Drop . . . . . . . . . . . . . 26

1.5.2 Impact on Side.............. 31

1.5.3 Puncture................ 35

1.6 Special Form . . . . . . . . . . . . . . . 35

1.7 Inner Container Design . . . . . . . . . . . . 36

2. THERMAL EVALUATION .................... . . 42

2.1 Discusston .. . . . . . . . . . . . . . . . 42

2.2 Therral Properties of Materials ............ 42

2.3 Thermal Evaluation for Normal Conditions of

Transport .................... 42

2.3.1 Thermal Model ............... 42

2.3.2 Maximur: iemperatures............ 49 
2.3.3 Mininur Temperatures ............ 49

2.3.4 Kaximan Internal Pressure ......... 49

2.3.5 Thermal Stress ................ 50

2.6 Hypothetical Theroa: Aicident Evaluation ....... SO

2.4.1 Fire Tegting................ st

2.4.2 Thermal Accident Analysis .......... 51

2.4.3 Container Temeratures ........... 52

2.4.4 Maxime Pressures .............. 52

2.4.5 Evaluation of Package Derformance ....... 52

3. containgent . . . . . . . . . . . . . . . . 56

3.1 Conta ment Boundaries ............... . 56

3.1.1 Special Form Shipments . . . . . . . . . 56

3.1 .2 other Shipments ............... 56

3.2 Requirements for Normal Conditions of Ixunsport . . . . 57

3.3 Requir enents for the Hypothetical Accident

Conditions . . . . . . . . . . . . . 57

4. SHIELDIKG ........................ 61

5. CRITICALITI. . . . . . . . . . . . . . . 61

6. QUALITY ASSURANCE ..................... . . 6́3

6.1 Pabrication, Inspection, and Acccptance Tests..... 63

6.2 Operating Procedures and Routine Inspection ..... . 64

6.3 Periodic Maintenance and Inspection .......... 64

REPEREACES ......................... 65

APPENDIX A - As-Built Drawings ................ 67

APPEMDIX B - APproval Documents . . . . . . . . . . 73

APPENDIX C - Routine Packaging and Inspection Procedures . : . 79

APPENDIX D - Hydrostatic Pressure Test and Computer Listing

for Composite Heads . . . . . . . . . . . 89

APPENDIX E - Pabrication Drawings of Full-Scale Test Model . . 105

APPENDIX F -- Model Testing Procedure and Report . . . . . . . 113

APPENDIX G - Shielding Analysfs . . . . . . . . . . . , 121

APPENDIX H - Crittcality Review . . . . . . . . . . . 125

APPENDIX I - Inspection Reports . . . . . . . . . . . 131

APPENL 'X $J$ - Thermal Study of LiOH (Niemo from R. J. Lauer to R. D. Seagren) .............. 139 


\section{LIST OF FIGURES}

Figure

$\underline{\text { Page }}$

0.1 LiOH shield ................... 3

1.1 Lifting load diagram ................ 7

1.2 Typical tie down ................. 12

1.3 Simple beam model . . . . . . . . . . . . . . 18

1.4 Impact test model ................. 28

1.5 Top impact test model . . . . . . . . . . . . 29

1.6 Models after testing . . . . . . . . . . . . 30

1.7 Schematic model testing . . . . . . . . . . 32

1.8 Special form encapsulation . . . . . . . . . . . 37

1.9 Special form encapsulation . . . . . . . . . . 38

$1.102 R$ container ................... . . 39

1.11 Typical $2 \mathrm{R}$ containers ............. 40

2.1 Thermal model .................. 44

2.2 Thermal model - suspended $2 \mathrm{R}$ container ........ 48

2.3 Temperature-time history for cask fire test ...... 53

2.4 Temperature-time history for cask cooldown . . . . . . 54

2.5 Thermal mode1 - LiOH losing wate: of hydration . . . . . 55

$3.12 R$ lest models . . . . . . . . . . . . . . . 58

3.22 test model ................. 59

A.1 As-bu11t drawing no. M-11566-EM-001-D . . . . . . 69

A. 2 As-butlt drawing no. M-11556-EM-002-D . . . . . . 70

A.3 As-built drawing no. M-11566-EM-003-D ........ 71

D.1 Calculatory model shield 1id.............. 92

D.2 Hyorostatic pressure test ............. 103 


\section{Plgure}

E.1 Fabrication drawing no. D-RD-2760 . . . . . . . . 107

E. 2 Fabrication drawing no. D-RD-2761 . . . . . . . . 108

E.3 Fabrication drawing no. D-RD-2762 ........... 109

E.4 Fabrication drawing no. D-RD-2763 .......... 110

E.5 Fabrication drawing no. D-RD-2764 ........... 111

F.1 Inpact test model . . . . . . . . . . . . . 116

F.2 Data acquisition system . . . . . . . . . . . 117

F.3 Yodels after testing . . . . . . . . . . . . 119 


\section{LIST OF TABLES}

Table

Page

1.1 Hechanical properties of cask materials ........ 6

1.2 Dimensions schedule for $2 R$ specification containers . . 41

2.1 Material properties used in thermal analysis ...... 43

2.2 Package temperatures during normal conditions of transport ................... 47

F.1 Impact data and results ................ 118

G.1 Dose rates from $\mathrm{LIOH}$ shield ............. 123 


\section{ACRNOWLEDGIENTS}

The contributions of K. W. Haff, R. W. Schaich, and R. D. Seagren of the ORML Isotopes Division, who furnished the information on original design, incended use, and the results of full-scale testing, and of N. C. Bradley, also of the ORNL Isotopes Division, who worked with the authors to perform model impact testing, are gratefully acionowledged. The contributions of G. H. Llewellyn of ORNL Engineering, who prepared the heat transfer analysis, J.W. Knight of the UCC-ND Computer Sciences Division, who performed the shielding analysis, 0 . J. Smith and the ORNL Inspection Engineering Department, who inspected the existing weldments, and $N$. D. Roberts of ORNL Engineering, who contributed to the design modifications and prepared the as-bullt drawings, are also ackiowledged. 
SAFETY ANALYSIS REPORT FOR PACKAGING: THE ORNL LITHIUM HYDROXIDE FIRE AND IMPACT SHIELD

J. H. Evans R. E. Eversole R. A. Just

ABSTRACT

The ORNL lithium bydroxide fire and impact shield was designed and fabricated at Oak Ridge National Laboratory to permit the transport of Type $B$ and large quantities of radioactive material and limited quantities of fissionable material. The shield was evaluated analytically and experimentally to determine its compliance with the applicable regulations governing containers in which radinactive and fissile materials are transported, and that evaluation is the subject of this report. Computational and test procedures were used to determine the structural integrity and thermal behavior of the shield relative to the general standards for normal conditions of transport and the standards for the hypothetical accident conditions. The results of the evaluation demonstrate that the shield is in compliance with the applicable regulations.

\section{GENERAL INFORMATION}

\subsection{Introduction.}

The ORNL 11thium hydroxide (LIOH) fize and impact shield was designed by the ORNL Isotopes Division in 1969. The original design was revised in 1973 to incorporate improvements and to upgrade the shieids. Six shields were built in 1970. One shield was filled with lithium hydroxide monohydrate $\left(\mathrm{LiOH} \cdot \mathrm{H}_{2} \mathrm{O}\right)$ and was then impact and fire tested as described in Sects. 1.5.1 and 2.4.1 of this report. The shields were inspected and examined, and one shield was filled with $\mathrm{LiOll} \cdot \mathrm{H}_{2} \mathrm{O}$ in accordance with the drawings and specifications in Appendix A.

The primary use of the shields is to provide impact and thermal resistance to Type $A$ and Specification 55 packages ${ }^{3}$ to permit the transport ot Type $B$ and large quantities of radloactive material and 11mited quantities of fissionable material $f(x$ both normal and accident conditions, by rail, highway, and water modes. The contents for which the design is evaluated are outlined in Sect. 0.2.3. The shield complies with Energy Research and Development Administration (ERDA) regulations, 
Title 10 CFR Part 71,2 ERDA Manual Chapter 0529, 1 and all Imediate Action Directives (IAD) in effect as of this report date. The shields also comply with U.S. Department of Transportation (DOT) regulations, Title 49 CFR Part 173. 3 Calculations, engineering logic, test results, and documents demonstrating compliance are presented in succeeding sections of this report. Coples of the approval documer:s are reproduced in Appendix B.

\subsection{Package Description :}

\subsubsection{Container description}

The features of the shield are illustrated in Fig. 0.1. As-built Eabrication drawings are in Appendix A. The shield consists of two right circular cylinders 36 and $27-1 / 4 \mathrm{in}$. In diameter, ecch $1 / 8 \mathrm{in}$. thick, forming the outer and inner cladding. The body or vessel is 30-3/4 in. high, and the lid or plug is 4-5/8 in. high. These form a cavity $27 \mathrm{in}$. in diameter by $26 \mathrm{in.} \mathrm{high.} \mathrm{The} \mathrm{4-1/4-in.} \mathrm{nominal} \mathrm{space}$ between outer and inner cladding is filled with $\mathrm{LiOH} \cdot \mathrm{H}_{2} \mathrm{O}$ crystals. After pouring, the crystals form a solid mass by absorption of waier. The outer surface of the vessel has 92 vertical cooling fins $1 / 8$ in. thick by 1 in. wide welded to the wall to improve heat dissipation to the atmosphere.

The closure consists of 2 pair of 44-1n.-diam reinforced flanges. Twenty seal-wired 1-in. alloy steel bolts secure the closure. There is no gasket, since containment is provided by the Type A or Specification 55 package containing the spectal form encapsulation or an inner $2 R$ containe $\mathrm{r}^{4}$ as discussed below. At the base of the vessel, the inner and the outer cladding are separated by a cross structure of pine lumber. Tire Inner and the outer cladding of the lid are spaced apart and supported by a strisctural member. The material of construction, with the except tlons noted above, is type 304L stafnless steel sheet, plate, and special shapes. The fire and impact shield weighs $1450 \mathrm{lb}$, and the total package weight will not exceed $4000 \mathrm{lb}$. 


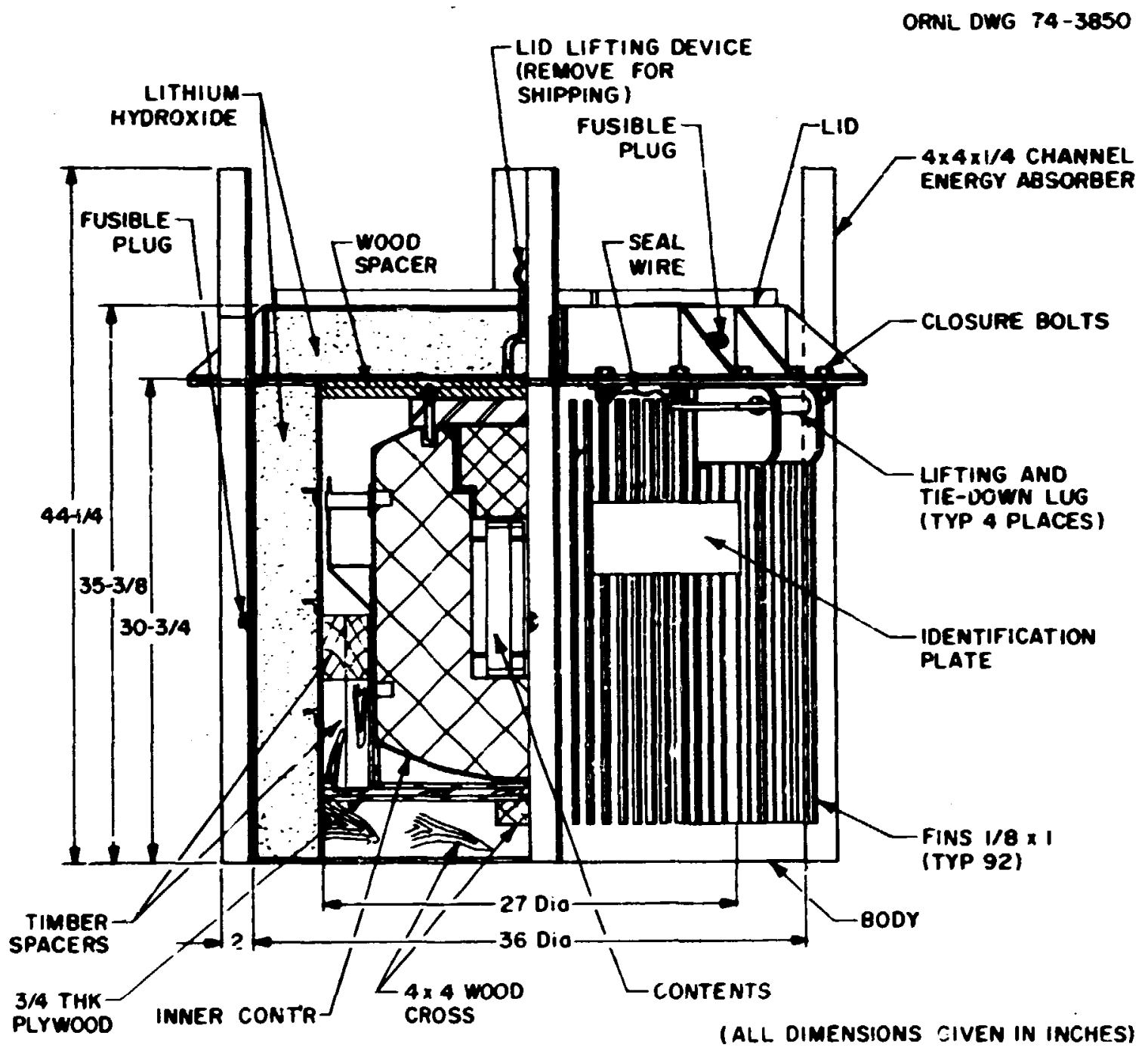

Fig. 0.1. LiOH shield. 


\subsubsection{Operational features}

The shield is designed to be 1sfted and tied down by lugs (see Sect. 1.2.?, FIg. 1.1). The four channels extending above the top offer Impact protection.

The $\mathrm{LAOH} \cdot \mathrm{H}_{2} \mathrm{O}$ forms neutron shtelding in addition to offering therma!

- protection. When required, gama shielding is provided by a shielded cask equivalent to or exceeding contaitment and constriction criteria outlined in DOT regulations. ${ }^{4}$ This cask would weigh 2500 lb or less for a total package welght of $4000 \mathrm{lb}$.

then radioactive material other than special form ${ }^{1,2}$ is shipped, it is packaged in an inner container which meets or exceeds the requirements of DOT Specification $2 R,{ }^{4}$ conforms to the allowable stress and design phIlosophies of Sect. VIII of the ASME Boiler ani Pressure Vessei Code, 5 has a high integrity seal, and has provisions for leak checking of vessel and seal.

All inner containers will be blocked in the LiOH shield with lumber such that movement in any radial or axial direction is $11 \mathrm{mited}$ to $1,4 \mathrm{in}$. or less. Movement of the inner vessel relative efther to the gamma shield or the LiOH shield as applicable will be restricted to $1 / 4 \mathrm{in}$. or less in a like manner.

\section{2 .3 Contents}

The contents of the inner container within the LiOH shield w11l be any solid, large quantity of radioactive materlals whose decay heat load does not exceed $300 \mathrm{~W}$ and whose gamma and/or neutron activity does not exceed dose rate $11 \mathrm{mits}$ specified in DOT regulations. ${ }^{4}$ The maximum quantity of ${ }^{242} \mathrm{Am},{ }^{244} \mathrm{Cm},{ }^{245} \mathrm{Cm},{ }^{247} \mathrm{Cm},{ }^{249} \mathrm{Cf}$, and ${ }^{251} \mathrm{Cf}$ will be limited to a combined total of $5 \mathrm{~g}$. The LiOll shield package will also be used to tran.jport up to $150 \mathrm{~g}$ of ${ }^{238} \mathrm{PuO}_{2}$ and up to $100 \mathrm{~g}$ of fissionable materials including ${ }^{235} \mathrm{U},{ }^{233} \mathrm{U}$, and ${ }^{239} \mathrm{Pu}$ in solfd form. The above materials will be.packaged internally to meet spectal form requirements or DOT Specificaton 2 R.

The LIOH package will carry irradiated metal specimers zuch as tensile, Impact, and weld specimens Including, but not limited to, 
stainless steel, mild steel, aluminum, INOR-8, nickel, high-nickel alloys such as Inconel and Monel, and tungsten. All such specimens will meet special form requirements or be contained in a DOT Specification $2 \mathrm{R}$ container.

\section{2 .4 LiOH cavities}

Cavities in the vessel and lid are filled with $\mathrm{LiOH} \cdot \mathrm{H}_{2} \mathrm{O}$, which provides neutron shielding and thermal protection. Lithium hydroxide monohydrate is a corrosive material as defined by DOT regulations ${ }^{4}$ (see 173.240) even though not specifically listed (see Part 172). Since the material is contalned in a stainless steel shell, the shields comply with the DOT requirements for corrosive materials containers (see 173.21 and $173.245 \mathrm{~b}$ ) and will be labeled as required (see 173.417).

\section{STRUCTURAI. EVALUATION}

\subsection{Mechanical Properties of Materials}

The properties of the materials used in the LiOH shield are listed in Table 1.1. For some materials dynamic properties are not available. In these instances, static properties are used, but care is exercised to ensure that their use results in a conservative evaluation.

\subsection{General Standards for All Packages}

The general standards for all packaging cover the chemical and galvanic reactions of the materials of the package, closure of the package, and the lifting and tie-down devices for the package. The st.lelds are constructed of 300-series stainless steel filled with $\mathrm{LiOH} \cdot \mathrm{H}_{2} \mathrm{O}$ salt. There has been no evidence of any corrosive or galvanic action between these materials.

\subsection{1 $\underline{\text { Closure }}$}

The standards specify that the package be equipped with a positive closure that will prevent inadvertent opening. The lid and body are secured with seal-wired bolts that qualify as a positive closure. 
Table 1.1. Mechanical properties of cask materials

\begin{tabular}{lccc}
\hline $\begin{array}{c}\text { Static and dynamic } \\
\text { properties }\end{array}$ & Symbol & $\begin{array}{c}304 \mathrm{~L} \\
\text { stainless steel }\end{array}$ & $\begin{array}{c}\text { Closure bolts } \\
\text { ASTM A320 }\end{array}$ \\
\hline Yield stress, psi & $\sigma_{y}$ & $30,000^{b}$ & $105,000^{c}$ \\
Ultimate tensile stress, psi & $\sigma_{\mathrm{u}}$ & $75,000^{b}$ & $125,000^{c}$ \\
Modulus, of elasticity, psi & $\mathrm{E}$ & $29 \times 10^{6^{j}}$ & \\
Ultimate elongation, in./in. & $E$ & 0.5 & $0.16^{c}$ \\
Poisson's ratio & $v$ & $0.3^{b}$ & \\
Density, 1b/in. & $0.283^{b}$ & \\
Allowable shear stress, psi & $\tau$ & $15,000^{d}$ & $52,500^{d}$ \\
Design stress, psi & & $14,400^{e}$ & \\
\hline
\end{tabular}

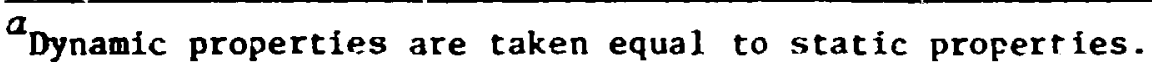

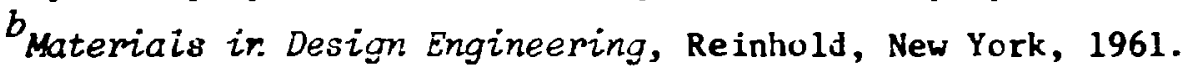

'Specification for Alloy Steel Bolting Materials for Low Temperature Service, ASME SA-320, ASHE Boiler and Pressu'e Vesse? Code, Section II, "Materials," American Society of Mechanical Engineers, New York, 1971. One-half yield stress.

$e_{\text {At }} 500^{\circ} \mathrm{F}$, design stress is applicable to pressure calculations only. Taken from ref. 5 .
}

\subsubsection{Cask 1ifting device}

If there is a system of lifting devices that is a structural part of the package, the regulations require that this system be capable of supporting three times the weight of the loaded package without generating stress in any raterial of the package in excess of its yield strength.

The shields are designed to be lifted by four lugs (see Fig. 0.1) spaced symmetrically around the shield, using conventional slings. It Is reasonable tu assume tilat on occaston only two lugs will be used; hence the lugs will be evaluated on this basis. The lugs are of type $304 \mathrm{~L}$ stainless steel, which has a yield stress of $30,000 \mathrm{psi}$. The force on the lugs is applied as shown in Fig. 1.1. 


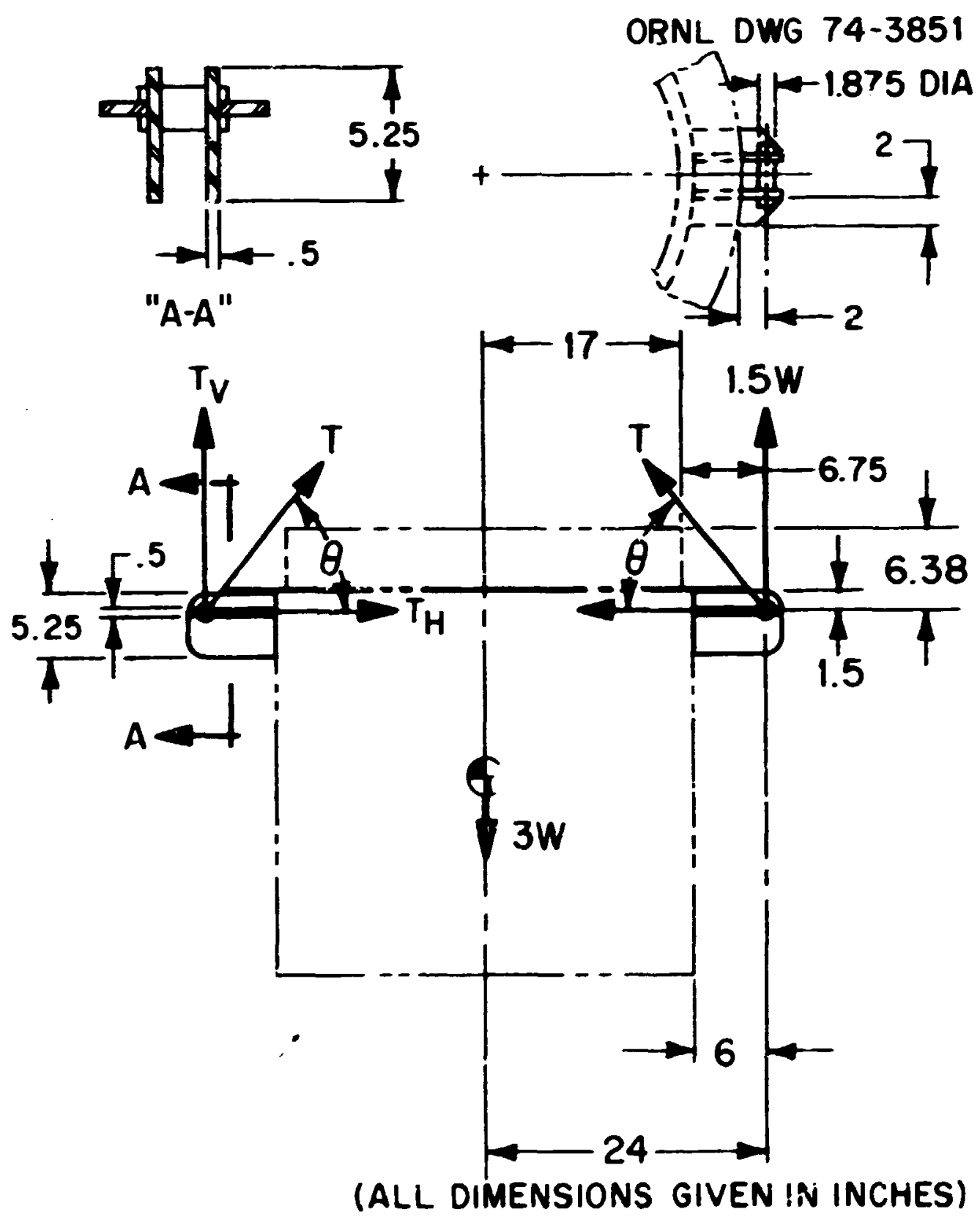

Fig. 1.1. Lifting load diagram. 

The centroid of Sect. A-A is found by the area momen: proposition

$$
\begin{aligned}
\bar{y} & =\left(A_{1} y_{i}+A_{2} y_{2}\right) /\left(A_{1}+A_{2}\right) \\
& =[(5.25)(0.5)(2.625)+(2)(0.5)(3.875)] /[(5.25)(0.5)+(2)(0.5)] \\
& =2.97 \mathrm{in.},
\end{aligned}
$$

where

$$
\begin{aligned}
& A_{1}=\text { cross-sectional area of support plates }\left(\text { in. }{ }^{2}\right), \\
& A_{2}=\text { cross-sectional area of flange }\left(\text { in. } .^{2}\right) .
\end{aligned}
$$

The moment of inertia about the centroidal axis is found by the transfer axis theorem

$$
\begin{aligned}
I & =\left[I_{0}+A^{2}=I_{1}+A_{1}\left(\bar{y}-y_{1}\right)^{2}+I_{i}+A_{2}\left(\bar{y}-y_{2}\right)^{?}\right. \\
& =2\left[1 / 12(0.5)(5.25)^{3}+(5.25)(0.5)(2.97-2.625)^{2}+1 / 1 \Sigma(2)(0.5)^{3}\right. \\
& \left.+2(0.5)(2.97-3.875)^{2}\right]=14.34 \mathrm{in.}^{4} .
\end{aligned}
$$

The maximum bending stress, $\sigma_{b}$, in the support plates resulting from $T_{v}$ is at $C-C$ and is found from

$$
\begin{aligned}
\sigma_{b} & =m c / I= \pm\left[F_{v} a(b / 2)\right] / I \\
& = \pm 6000(2)(5.25) / 2(14.34) \because+2200 \mathrm{psi} .
\end{aligned}
$$

The compressive stress, $\sigma_{r}$, in the plates resulting fröt $T_{H}$ is

$$
\sigma_{c}=T_{H} / A=6350 / 2[(5.25)(0.5)+(2)(0.5)]=880 \mathrm{ps} 1 .
$$

The maxinum stres, $;$, is

$$
\sigma=c_{b}+\sigma_{c}=2200+880=2080 \mathrm{psi} .
$$


The force, $i_{H}$, loads the shell in compression and the weld securing the support plates to the flange in shear. Assuming that the weld carries all the load, the maximu shearing stress, ${ }_{H}$, in the weld is

$$
T_{H}=T_{B} /(e)(\cos 45) S=6350 /(0.25)(\cos 45)(16)=2250 \text { psi, }
$$

where

$$
\begin{aligned}
& e=\text { weld size }=1 / 4 \text { in., } \\
& S=\text { total length of we!d (in.). }
\end{aligned}
$$

The force $T_{v}$ loads the weld securing the support plates to the shell. As above, the shearing stress in the weld is

$$
T_{v}=T_{v} /(e)(\cos 45) S=6000 /(0.25)(\cos 45)(4)(5.25)=1620 \mathrm{psi}
$$

These stresses are less than the allowable stresses (see Table 1.1); hence the shield conplies with the lifting requirements.

Faflure of the lifting device under excessive load would prubably be a bending failure of the 1.875-1n.-diam rod, since it is the most highly stressed nember. Pallure of the rod or any other part of the lifting device would not impair the shielding and containment capabilities of the shield.

\subsubsection{Lid-1ifting device}

The regulations require that if there is a system of lifting devices that 18 a structural part of the lid only, this system shall be capable of supporting three times the weight of the lid and any attachment without generating stress in any material of the lid in excess of 1 ts yield strength. It is further required that unless rendered useless for lifting during transport of the package, the lid-1ifting or any other system of lifting devices shall conform to the requirements for the package lifting system.

The 11d, which weighs appru:-1mately $310 \mathrm{lb}$, is lifted by a $1 / 2-1 \mathrm{n}$. eyebolt located at the center. Tie safe working load for the eyebolt 
is $26001 \mathrm{~b},{ }^{8}$ which is in excess of three times the veight of the 1 id. The eyebolt is removed for shipping; hence it is not available for lifting the entire cask during transport (see Appendix $C$ ).

Failure of the lid-lifting device under excessive load would be in the form of a tensile failure of the eyebolt which would not impair the shielding or containment capabilities of the shield.

\subsubsection{Tie-down devices}

If there is a system of tie-down devices that is a structural part of the package, the regulations require that this system be capable of withstanding a static force applied to the center of gravity of the package with a vertic:il component of two times the weight of the package and $i$ ts contents, a horizontal component along the direction of travel of ten times the weight of the package and its contents, and a horizontal comfonent in the transverse direction of five times the weight of the package and its contents. This applied force shall not generate stresses in any material of the package in excess of the yield strength of that material. It is also required that any tie-down device that is a structural part of the package shall be so designed that failure of the device under excessive load will not impair the ability of the package to meet other requirements of the regulations.

The LiOH shield is designed to be secured to the transport vehicle as shown in Fig. 1.2 by four tension members attached to the four lifting and tie-down lugs. For the general case, the notation $\mathrm{I}, \mathrm{J}, \mathrm{K}, \mathrm{H}$, and $\mathrm{I}$. of Fig. 1.2 represents the dimensions of the tie-down system. Of these, only the value of $H$ is fixed by the container geometry.

It cannot be determined by inspection if the forward members $C$ and $D$ are under load. If they are under load, the normal force, $F_{n}$, will be located on the outer radius of the shield. To determine wisether $C$ and $D$ are loaded, $1 t$ will be assumed that they are not, and the location of $F_{n}$ will be calculated. If the calculated location is within the confines of the shield base, these members are not loaded. However, if the calculated location is not within the boundary of the base, the members $C$ and $D$ must be under load to achierse equilibrium. 
ORNL DWG 74-3852

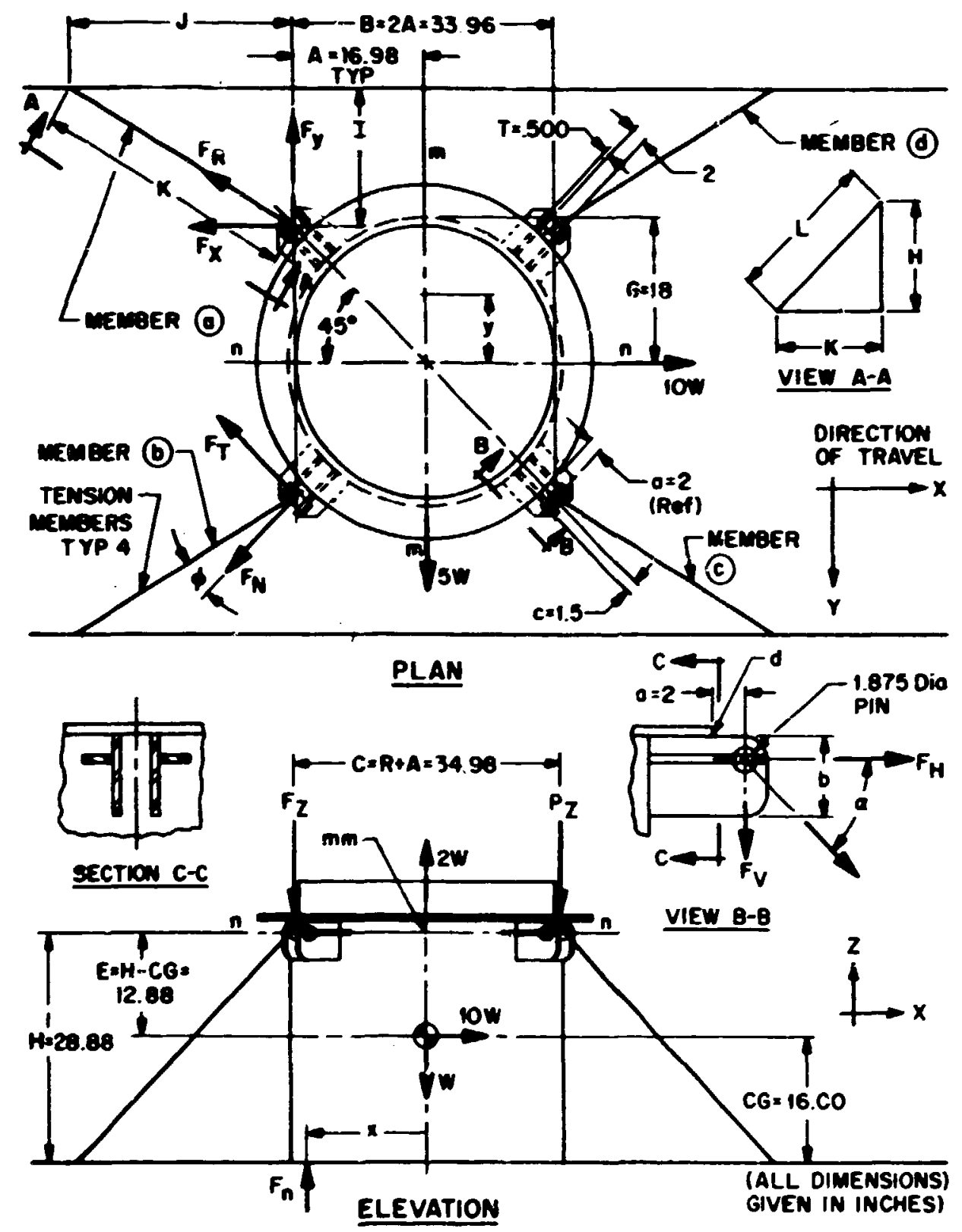

F18. 1.2. Typical lie down. 
For the 10W load. by summation of horizontal forces (see Fig. 1.2), $F_{x}=5 W$. It follows that the horizontal resultant in the disection of the tie-down member is $F_{R}=5 W(K / J)$. The tension in each of the two rear tie-down members is $T_{10}=5 \mathrm{~W}(\mathrm{~L} / \mathrm{J})$. For the $5 \mathrm{~W}$ transverse load, the tension in member a and in member $d$ is $T_{5}=2.5 \mathrm{~W}(\mathrm{~L} / \mathrm{I})$. The $2 \mathrm{~W}$ vertical load has a net resultant of $W$ upward and is equally distributed between the four tie-down members. The tension in each member as a result of the upward load is $T_{2}=(\mathrm{W} / 4)(\mathrm{L} / \mathrm{H})$. The tension, $\mathrm{T}$, in the most loaded member is $T_{a}=T_{10}+T_{5}+T_{2}=5 W(L / J)+2.5 W(L / I)+(W / 4)(L / H)=W L(5 / J$ $+2.5 / \mathrm{I}+0.25 / \mathrm{H})$. The values of the dimensions $\mathrm{I}$ and $\mathrm{J}$ w1ll vary over a considerable range in practice. Ratios of 1 to $J$ will be in the range $1 / 1$ to $1 / 2$. For highway trailers, the msot likely mode of transport for the shields, an $I$ to $H$ ratio of near $1 / 1$ is likely. These ratios are selected to demorstrate compliance with the tie-down requirements. Take $H$ as the reference height of a tie-uown, and letting $I / J=1, K=2^{1 / 2}$, $L=3^{1 / 2}$, and $T_{a}=H(3)^{1 / 2}(5+2.5+0.25)=13.42 W$. Similarly, for the $I / J$ ratio of $1 / 2$ and $H=$ reference height, $K=5^{1 / 2}, L=6^{1 / 2}$, and $T_{a}=W(6)^{1 / 2}(5 / 2+2.5 / 1+0.25 / 1)=12.86 \mathrm{~W}$.

The $I$ to $J$ ratio of $1 / 1$ results in the larger of the loads considered in the tie-down lugs, and the evaluation will be made on this basis. The tensile forces and component loads in the members are

$$
\begin{aligned}
& T_{a}=13.42 \mathrm{~W}, \\
& T_{b}=W(3)^{1 / 2}(5+0.25)=9.09 \mathrm{~W}, \\
& T_{c}=W(3)^{1 / 2}(0.25)=0.43 \mathrm{~W}, \\
& T_{d}=W(3)^{1 / 2}(2.5+0.25)=4.7 f, W, \\
& F_{z a}=T_{a} H / L=13.42 W / 3^{l / 2}=7.75 \mathrm{~W}, \\
& F_{z b}=9.09 \mathrm{~W} / 3^{1 / 2}=5.25 \mathrm{~W}, \\
& F_{z c}=0.43 W / 3^{1 / 2}=0.25 \mathrm{~W}, \\
& F_{z d}=4.76 / 3^{1 / 2}=2.75 \mathrm{~W}, \\
& F_{n}=\Sigma F_{z}-W=15 \mathrm{~W} .
\end{aligned}
$$


Sumation of moments about axis $\mathbb{m - m}$ yields $\sum M_{m-m}=0$ :

$$
\begin{aligned}
& \Sigma M_{\mathrm{D}-\mathrm{E}}=F_{n} X-10 \mathrm{WE}+\left(-F_{z_{j}}-F_{z b}+F_{z c}+F_{z d}\right) A=0, \\
& X=[10 \text { WE }+(7.75+5.25-0.25-2.75) \text { HA }] / 15 \text { W } \\
& =(E+A) / 1.5=(12.88+16.98) / 1.5=19.9 \text { in. }
\end{aligned}
$$

Sumation of moments about axis $n-n$ yields $\sum M_{n-n}=0$ :

$$
\begin{aligned}
\sum M_{n-n} & =F_{n} Y-5 W E+\left(-F_{z a}+F_{z b}+F_{z c}-F_{z d}\right) A=0 \\
Y & =[5 W E+(7.75-5.25-0.25+2.75) W A] / 15 H \\
& =(E+A) / 3=(12.88+16.98) / 3=9.95 \mathrm{in} .
\end{aligned}
$$

The normal force $F_{n}$ is located at a radius $r=\left(X^{2}+Y^{2}\right)^{1 / 2}=$ $\left(19.9^{2}+9.95^{2}\right)^{1 / 2}=22.25$ in., which has a slope of $y /-x=1 /-2$. This coincides with the line of action of the resultant of the $10 \mathrm{~W}$ and $5 \mathrm{~W}$ forces. The calculated location of $F_{n}$ is not on the container base. This demonstrates that there is additional tension in the members. The radius, $r$, cannot exceed 18 in., and the expression $r=\left[X^{2}+(X / 2)^{2}\right]^{1 / 2}$ $=X(5)^{1 / 2} / 2$. Solving for $X, X=2(18) / 5^{1 / 2}=16.1$ in. and $Y=X / 2=8.05$ in. Considering only the 10W load and again suming lisments about axis m-m,

$$
F_{n} X-2 F_{2} A+2 P_{z} A-10 W E=0,
$$

where $F_{z}$ is the vertical component of the tension, $T$, in member $a$ and in member $b$, and $P_{2}$ is the vertical component of the tension, $T$ ', in member $c$ and in member $d$. By summation of vertical forces, $F_{n}=2\left(F_{z}+P_{z}\right)$. By summation of horizontal forces, $2 \mathrm{~T}(\mathrm{~J} / \mathrm{L})-10 \mathrm{~W}-2 \mathrm{~T}^{\prime}(\mathrm{J} / \mathrm{L})=0$, and $T=5 \mathrm{WL} / J+T^{\prime}$. The vertical components $F_{z}=T(H / L): 5 W H / J+T^{\prime}(H / L)$ and $P_{z}=T^{\prime}(H / L)$. Substituting in the moment equation ytelds 


$$
\begin{aligned}
& 2 F_{z} X+2 P_{2} X-2 F_{z} A+2 P_{z} A-10 W E=0, \\
& F_{z}(X-A)+P_{z}(X+A)-5 W E=0, \\
& T(H / L)(X-A)+T^{\prime}(H / L)(X+A)-5 W E=0, \\
& \left(5 W L / J+T^{\prime}\right)(X-A)+T^{\prime}(X+A)-5 W E L / H=0, \\
& 5 W L X / J+T^{\prime} X-5 W L A / J-T^{\prime} A+T^{\prime} X+T^{\prime} A-5 W E L / H=0, \\
& 5 W L(X / J-A / J-E / H)+2 T^{\prime} X=0 .
\end{aligned}
$$

Making the notation change $T^{\prime}=T^{\prime} 10$ and solving,

$$
\begin{aligned}
T_{10}^{\prime} & =5 \mathrm{WL} / 2 \mathrm{X}(\mathrm{A} / \mathrm{J}+\mathrm{E} / \mathrm{H}-\mathrm{X} / \mathrm{J}) \\
& =5(4000) \sqrt{3} / 2(16.1)[16.98+12.88-16.1] \\
& =14,8001 \mathrm{~b}=3 . \mathrm{TW},
\end{aligned}
$$

where $P_{2}=$ vertical component of the tension in members $b$ and $c$, and $F_{z}=$ vertical component of the tension in members a and $d ; i t$, can be seen by inspection that $T^{\prime}{ }_{5}$, the tension in members $b$ and $c$, is zero, since the results at $F_{n}$ are located within the base. The tension, $T_{a}$, in the most loaded member, member $a$, is

$$
\begin{aligned}
T_{a} & =\left(T_{10}+T_{5}+T_{2}+T^{\prime}{ }_{10}\right)=17.12 \mathrm{~N} \\
& =68,5001 \mathrm{~b} .
\end{aligned}
$$

The shearing stress, $\tau$, in the pin is

$$
T=T_{a} /(2 A)=68,500 /\left[(2)(\pi)(1.875)^{2} / 4\right]=12,400 \text { psi. }
$$

The bending stress; 9 , in the rod, considering the rod as a beam with restrained ends, is 


$$
\begin{aligned}
\sigma & =\mathrm{M} / \mathrm{Z}=\left[\mathrm{T}_{\mathrm{a}} \mathrm{L} / 8\right] /\left[(\pi)(\mathrm{D})^{3} / 32\right] \\
& =[(68,500)(2)(4)] /\left[(\pi)(1.875)^{3}\right]=26,500 \mathrm{psi} .
\end{aligned}
$$

To determine the maximy stress in the tie-down lug (point d, Fig. 1.2, view B-B), the component stresses $\left(\sigma_{v}\right.$ and $\left.\sigma_{H}\right)$ are calculated and sumed. The force (see Fig. 1.2) is

$$
F_{v}=T_{a}(H / L)=0 ́ 8,500(1) / 3^{l / 2}=39,5501 b .
$$

The mont of inertia from Sect. $1.2 .2=14.34$.

As before, the bending stress

$$
\sigma_{v}=\mathrm{Mc} / \mathrm{I}=\mathrm{P}_{\mathrm{v}} \mathrm{a}(\mathrm{b} / 2) / \mathrm{I}=(39,550)(2)(2.5) / 14.34=13,800 \mathrm{psi} .
$$

The force $\mathrm{F}_{\mathrm{B}}=\mathrm{T}_{\mathrm{a}}(\mathrm{K} / \mathrm{L})=68,500\left(2^{1 / 2} / 3^{1 / 2}\right)=55,900 \mathrm{lb}$, so the direct tensile stress is

$$
\sigma_{H}=\mathrm{F}_{\mathrm{H}} / \mathrm{A}=55,900 /[(2)(0.500)(5.25)+2(0.500)(2)]=7700 \mathrm{ps} 1 .
$$

The maximum stress at point d (see Fig. 1.2, view A-A) is

$$
\sigma=\sigma_{v}+s_{H}=13,800+7700=21,500 \mathrm{psi} .
$$

The four vertical channels extending above the shield could be used to tle it down. The dimensional ratios previously used are valid; hence the maximum force in the most loaded tie-down member $1868,500 \mathrm{lb}$. The horizontal component of the force,

$$
F_{H}=T_{a}(K / L)=68,500\left(2^{1 / 2 / 3^{1 / 2}}\right)=55,9001 b,
$$

would place the built-up portion of the channel-14 shear. This shearing stress would be

$$
\tau=F_{B} / A=55,900 /[(4+2+2)(1 / 2)]=14,000 \mathrm{psi} . .
$$


The vertical component of this force, $F_{Z}$, would load the shield locally in compression in the area around the charnel and would be of little consequence.

All normal stresses are less than the yield point, 30,000 osi for stainless steel, and shearing stresses are less than the allowable shear stress. Various tie-down geometries are possible when securing the shipping container to the transport vehicle. The most likely tie-down geometry was used in the analysis, which showed that normal stresses are less than the allowable shear stress. If under extreme load the tie-down device fails, damage will be localized to the area of the tiedown lug. This area of the container does not contribute to the function of the shipping container. Fallure would not impair the containment or shielding properties of the overall package. Hence the package conforms to the tie-down requirements.

\subsection{Standards for Type B and Large-Quantity Packaging}

The structural standards for large-quantity packaging cover load resistance of the packaging and the external pressure which the package must withstan'. The ORNL lithium hydroxide shield complies with these requirements as disiussed in the following subsections.

\subsubsection{Load resistance}

When regarded as a simple beam supported at its ends along any major axis, the shield must be capable of withstanding a static load normal to and uniformly distributed along its length tisat is equal to five times its fully loaded weight without generating stress in any material of the container in ex sess of the yield strength of that material. The equivaient cross section of the container analyzed in this study is illustratud in Fig. 1.3.

The cross section of the LiOH shield is composed of the outer stainless steel sinell, the $\mathrm{LIOH} \cdot \mathrm{H}_{2} \mathrm{O}$ salt, and the inner rtainless steel shell as shown in Fig. 1.3. Since these components are symetrical about the same axis, the moment of inertia for the section is the sum of the moment 
18

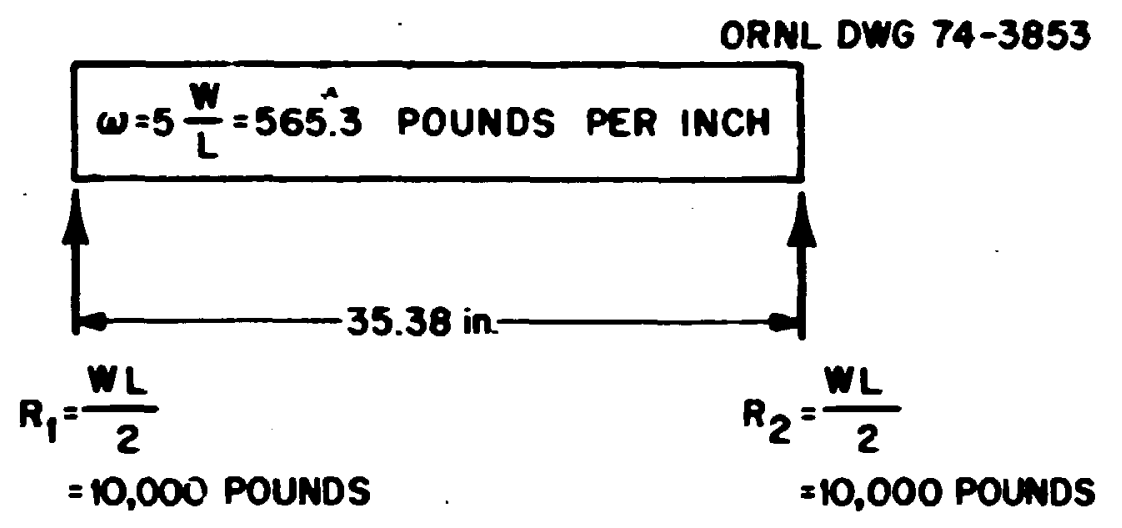

(a) CONTAINER AS SIMPLE BEAM

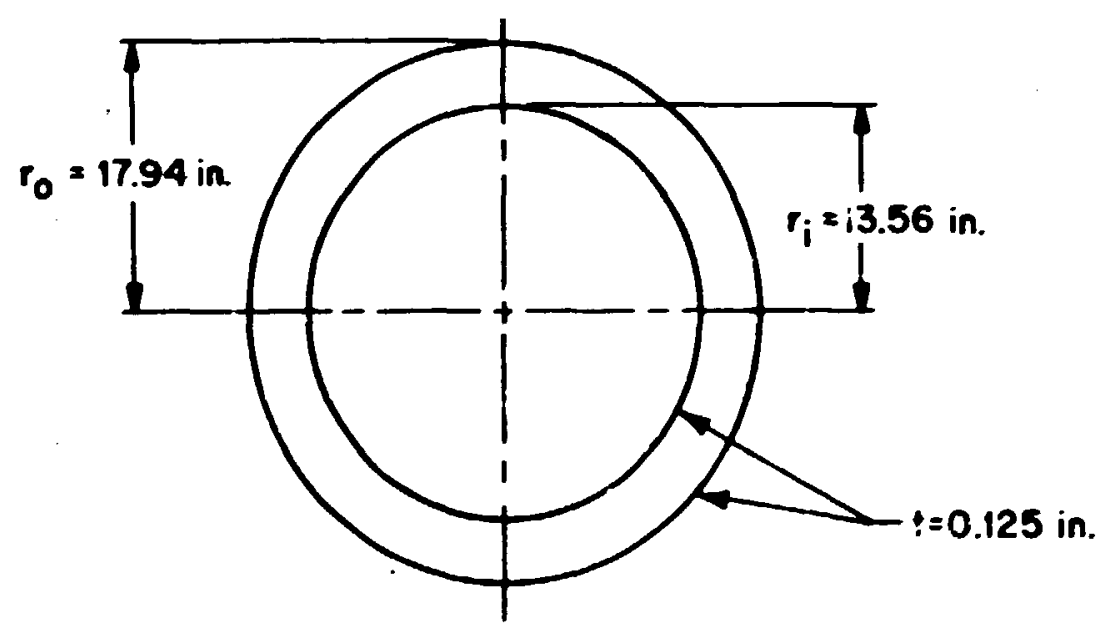

(b) EQUIVALENT CROSS SECTION OF CONTAINER

F18. 1.3. Simple beam mode:.. 
of inertia of the individual components. For a thin shell the moment of inertia about its center is

$$
I_{s}=\int y^{2} d A=\int_{0}^{\pi / 2}\left(r_{m}^{2} \sin ^{2} \theta\right) t r_{m} d \theta=\pi r_{m}^{3} t
$$

where

$$
\begin{aligned}
r_{m} & =\text { mean radius (in.). } \\
t & =\text { thickness (in.): }
\end{aligned}
$$

Neglecting the effect of the LiOH $\cdot \mathrm{H}_{2} \mathrm{O}$ and since $t_{0}=t_{1}=t$, the moment of inertia of the composite section is

$$
I=-\left(r_{0}^{3}+r_{1}^{3}\right) t=\pi\left[(17.94)^{3}+(13.56)^{3}\right](1 / 8)=3250 \text { in. }^{4} .
$$

The maximum bending stress is

$$
\begin{aligned}
\sigma & =M c / I=\omega(L)^{2} r_{0} /(8 I)=\left[(565.3)(35.38)^{2}(17.94)\right] /[(8)(3250)] \\
& =490 \mathrm{psi},
\end{aligned}
$$

where $\omega=$ weight per unit length ( $1 \mathrm{~b} / \mathrm{ln}$.), which 18 small compared with the yield strength of the material.

\subsubsection{External pressure}

Th regulations require that the shipping package be adequate to assure that the vesse! will suffer no loss of contents if subjected to an external pressure of $25 \mathrm{psig}$. For calculational purposes it w1ll be assumed that the $\mathrm{LIOH}$ cavity is at atmospheric pressure.

A potential consequence of external pressure ts buckling of the cylindrical shells. The outer shell of the vessel or body is probably the most vulnerable shell from a buckling standpoint. It is strengthened by the fins and four channels and supported by the LiOH· $\mathrm{H}_{2} \mathrm{O}$; hence it is 
not readily analyzed. If w: take the conservative approach of neglecting these reinforcements and assuming the simplified model of a right circular cylinder $26 \mathrm{in}$. In outside diameter by $30.25 \mathrm{in}$. long by C.125 in. in wall thickness with closed ends, the critical (buckifng) pressure can be determined using equations publist.ed by Faupel. 6 For axisymetric (bellows type) buckling, the critical pressure is found from

$$
\begin{aligned}
P_{c r} & =\left[2 E\left(t / r_{\mathrm{m}}\right)^{2}\right] /\left[3\left(1-v^{2}\right)\right]^{1 / 2} \\
& =\left[2\left(29 \times 10^{6}\right)(0.125 / 18.0)^{2}\right] /\left[3\left(1-0.3^{2}\right)\right]^{1 / 2} \\
& =1693 \mathrm{psig} .
\end{aligned}
$$

For lobar buckling,

$$
\begin{aligned}
P_{c r} & =\frac{1.345 E\left(t / r_{m}\right)^{5 / 2}}{\left(1-v^{2}\right)^{3 / 4}\left[(1.57)\left(L / r_{m}\right)-\left(t / r_{m}\right)^{1 / 2}\right]} \\
& =\frac{1.345\left(29 \times 10^{6}\right)(0.125 / 18.0)^{5 / 2}}{\left(1-0.3^{2}\right)^{3 / 4}\left[(1.57)(30.25 / 18.0)-(0.125 / 18.0)^{1 / 2}\right]} \\
& =66 \text { psig. }
\end{aligned}
$$

Since she critical buckling pressure of 66 psig is greater than 25 psi, the shej.ls will not buckle.

External pressure would load the flat ends of both the base and 1 id. The plates forming the inner and outer heads are braced by the crossed 4 by 4 lumber and the 11d plates by the lifting socket.

Both sets of plates are also supported over their entire area by the $\mathrm{LiOH} \cdot \mathrm{H}_{2} \mathrm{O}$, which has a $\mathrm{cl}$ ing strength in excess of $25 \mathrm{psig}$. It is therefore coicluded that the heads will not fail when subjected to the 25-ps18 external pressure.

Primary containments formed by the special form or $2 R$ container will withstand the 25-psig externa] pressure, since tiney are tested (see Sect. 1.7 and ref. 5) at 1.5 times the design pressura of 21 psig. 


\subsection{Compliance with standards ior Normal conditions of Transport}

The regulations for normal conditions of transport for a single package require that the effectiveness of the package will not be substantially reduced by the normal conditions of transport and that there will be no release of radioactive material from the containment vessel. The contents of the container are limited such that there will be no gases o vapors in the package that could reduce the effectiveness of the packaging. There is no circulating coolant othr than atmospheric air, and there is no mechanical cooling device required or provide.. The shield and the inner container(s) are so designed that the contents will not be vented to the atmosphere under normal conditions of transport. These normal conditions include the effects of heat, cold, pressure, free drop, and penetration.

\section{4 .1 Heat}

The package must be able to withstand direct sunlight at an ambient temperature of $130^{\circ} \mathrm{F}$ in still air without reducing the effectiveness of the packaging. A computer program, ${ }^{7}$ HEATING 3 (see Sact. 2.0), was used to compute the steady-state temperature distribution in the package and its contents under the specified conditions. The dimensional model is shown in Fig. 2.1 and the input constants in Table 2.1. The computed remperatures at locations of concern are outlined in Table 2.2. These temperatures will not adversely affect the shields. The materials of construction do not suffer significant loss of physical properties at these temperatures. The continuous operating temperature limit of the silicone rubber $0-r i n g s$ in the $2 \mathrm{R}$ container is $300^{\circ} \mathrm{F}$, which is above the calculated seal temperature. The LiOH cavity temperature is below the level where water of hydration would be lost, and the maximum calculated surface temperature is below the ninimum release temperature of the fusible plugs $\left(208^{\circ} \mathrm{F}\right.$ ). The calculatet pressures (see Sect. 2.3.4) will not adversely affect the shields.

The DOT regulations stipulate that the temperature of any accessible surface of the fully loaded shipping package shall not exceed $122^{\circ} \mathrm{F}$ when 
the package is in ine shade in still air at an ambient temperature. For this evaluation, anbient temperature vas assured to be $100^{\circ} \mathrm{F}$, and the referenced computer progran ${ }^{7}$ was used to compute the maximum shield surface temperatire with the shield loaded with a heat load of $300 \mathrm{~W}$. The maximu accessible surface temperature was found to be $118^{\circ} \mathrm{F}$, wich occurred at the centerline on the bottom of the vessel.

\section{4 .2 Cold}

The shipping package wust be able to withstand an ambient temperature of $-40^{\circ} \mathrm{F}\left(420^{\circ} \mathrm{R}\right)$ in still air and shade. Using the same methods of analysis used in Sect. 1.4.3 and assuming no internal beat load, the final or maximum pressure $(P)$ in any cavity sealed at a pressure of 14.7 psia and a temperature of $70^{\circ} \mathrm{F}\left(530^{\circ} \mathrm{R}\right)$ is

$$
P=P_{1} T_{2} / T_{1}=(14.7)(420) /(530)=11.65 \mathrm{psia} .
$$

The resulting pressure differential is not significant by comparison with the 25-psig external pressure of Sect. 1.3.2. A temperature of $-40^{\circ} \mathrm{F}$ is within the operating temperacure range of the materials of the package. Brittle fracture of the shield under the stipulated cold condition is not credible because the temperatures of all the components of the shield will be above the ductilc-to-brittle transition temperatures of the materials from which the shields are ronstructed. Therefore, the stipulated cold condition will not reduce the effectiveness of the packaging, and the packare conforms to the requirements for the cold condition of normal transport.

\subsubsection{Pressure}

The regulations for normal conditions of transport specify that the pacixage be able to withstand an atmospheric pressure of 0.5 times the standard atmospheric pressure, the resulting pressure being 7.35 psta. The shield is not equipped with a gasket; hence the cavity would also be at the redured pressure. The lioH cavities are sealed: therefore the pressure would not drop. This reduced atmospheric pressure is aiditive 
to the internal pressures in the !.iOH cavities attributable to the elevated temperatures resulting from decay heat of the contents and atmospheric conditions (see Sects. 1.3 and 2.0). The inner containers (secondary and/or primary containment) are designed to withstand this differentiai (see Sect. 1.7).

The pressure differential in the LiOH cavities of the body whuld be the sum of $7.35 \mathrm{a}_{\mathrm{i} . \mathrm{j}} 3.3$, or $10.65 \mathrm{psi}$, and for the cover cavity the sum of 7.35 and 2.41 , or 9.76 psi (see Sects. 2.3.2 and 2.3.4). By comparison with the calculations of Sect. 1.3.2, the incer cylinders will not buckle. The hoop stress, $\sigma_{h}$, in the outer cylinder would be

$$
\sigma_{h}=P_{2} / t=(10.65)(18) /(0.125)=1540 \mathrm{psi} \text {, }
$$

where

$$
\begin{aligned}
& P=\text { pressure (psi) } \\
& r=\text { radius (in.) } \\
& t=\text { vall thickness (in.). }
\end{aligned}
$$

The flat heads of the base and the cover are connected at the center. The plates forming the base head are $1 / 4 \mathrm{in}$. thick, while the cover is formed by a 1/4-in.-thick lower plate and a braced 1/8-in.-thick upper plate. The plates in the lid represent a more stressed condition than do the plates in the body due to the center support (see Fig. 0.1).

Calculation techniques for determining the stress in the $1 / 8-i n$. reinforced plate were not evident in the literature; conse?uently, the lid was hydrostaticaiiy pressure tested to decermine its ability to withstand che reduced pressure requirement. The lid was pressurized to 11 psig and the deflection measured at various pressures. The results of this test are presented in Appendix $D$.

The 1/4-in. lower plate could be analyzed, and the formulas for this calculation have been coded into a FORTRAN program. The derivation of this program is presented in Appendix $D$ along with the compilation of the program.

The hydrostatic pressure test of the head indicates that there was no significant permanent deformation of the $1 / 8-1$ n. reinforced plate; 
iherefore, yield stress was not exceeded. The calculation for the 1/4-in. lower plate revealed maximum point stresses at or lear the yield pcint of the material; hence, significant deformations will not occur. It is therefore concluded that the package complies with the reduced atmosphere requirement.

\subsubsection{Vibrations}

The regulations require packages to withstand the vibrations normally incident to transport.

The shields are of welded construction, and all welds are complete penetration. Transport vibrations are not expected to affect the integrity of the shield weldment. The $\mathrm{LiOH} \cdot \mathrm{H}_{2} \mathrm{O}$ forms a hard cake after filling. Vibrations are not expected to cause cracks or settling. Fasteners will be seal wired and will not loosen due to transport vibrations.

\subsubsection{Water spray}

The regulation specifies that package effectiveness not be reduced when subjected to a water spray sufficiently heavy to keep the entire surface of the package except the bottom continuously wet for a period of $3 \mathrm{~min}$.

The specified wate- spray will not affect the integrity of the stainless steel LiOH shield.

\subsubsection{Free dro:}

The regulations for nomal conditions of transport require that a package weighing less than $10,000 \mathrm{lb}$ be capable of withstanding a free drop through a distance of $4 \mathrm{ft}$ onto a flat, essentially unylelding, horizontal surface, strinking the surface in a position in which maximum damage is expected to result.

Orily for the corner drop is impact dizectly on the contafner body. All other Jrop orjentations result in impact on an extension of the body, for example, cooling fins, which acts as an energy absorber. Therefore 
the maximum damage would result fron a drop onto the top cormer. There would be some local permanent deformation of the lid. The corner welds are of a design and quality that a rupture would not likely occur. Containment kould be maincained, and the deformation would not affect the heat transfer capabilities of the package. These conclusions are based on the results of the 30-ft and 40-in. free-fall tests of the ful:-scale model discussed in Sect. 1.5 and the testing of a 3800-1b container employing gypsim plaster in lieu of the LiOH reported by Evans. ${ }^{14}$ If a weld rupture did occur, routine inspections (see Appendix C) would result in detection and repair before further usage.

\subsubsection{Penetration}

The regulations for normal condftions of transport also stipulate that the package be capable of withstanding the impact of the hemispher-tcal end of a vertical steel cylinder which weighs $131 \mathrm{~b}$, has a diameter of 1-1/4 in., and is dropped frum a helght of $40 \mathrm{in.}$, nomally onto the exposed surface of the package that is expected to be the wost vulnerable to puncture. This test was conducted on an unfilled LiOH shield and did not reduce the effectiveness of the shield. The results were no more than a very superficial dent in the stainless steel surface of the LiOH shield.

\subsubsection{Compression}

It is required that packages weighing less than $10,000 \mathrm{lb}$ be capable of withstanding a compression load of five times the container weight, ur $2 \mathrm{lb} / \mathrm{in} .^{2}$, distributed uniformly across the top and bottom, whichever is greater. Five times the weight of the container is greater than 2 psi for the LiOH shield. The maximum compressive stress occurs in the $11 \mathrm{~d}$ and is, neglecting the contribution of the $\mathrm{LiOH} \cdot \mathrm{H}_{2} \mathrm{O}$,

$$
\sigma=\mathrm{P} / \mathrm{A}=(\mathrm{SW}) /\left(\pi \mathrm{D}_{0} t\right)=[(5)(4000)] /[(\pi)(34.0)(0.125)]=1500 \mathrm{psi},
$$


where

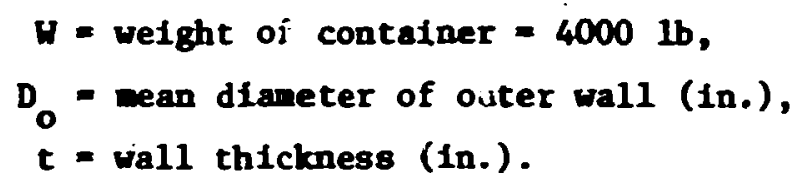

The shield adequately weets this requirement in thet the stresses generated by the compression load are very much less than the allowable yleld stress.

\subsection{Compliance with Standards for Hypothetical Accident Conditions}

The standards for the hypothetical accident conditions stipulate that a package used for the shipment of f1ssile or a large quantity of radioactive material shall be so designed and constructed and its contents so limited that if it is subjected to the specified free-drop, puncture, thermal, and water imersion conditions, the reduction in shielding would not be suffictent to increase the external radiation dose race to more than $1000 \mathrm{millirems} / \mathrm{hr}$ at $3 \mathrm{ft}$ from the outside surface of the package, no radioactive material would be released from the package except for gases and contaminated coolant not to exceed 0.17 of the total radioactivity of the conteits of the package, or specific activity levels spectfled in the regulations by transport group, and the contents would remain subcritical.

The effects of the free drops are discussed below, and the effects of the thermal exposure are discussed in Sect. 2. The water immersion would result in the cavity belng flooded and the LiOH cavities being partially filled with water. The degree of filling would depend on ahield orfentation. The flooding would not result in criticality (see Sect. 5). Little if any of the LIOH would go 1nto solution and be lost.

\subsubsection{Pree drop}

The first in the sequence of hypothetical accident conditions to which the cask must be subjected 18 a free drop through a distance of $30 \mathrm{ft}$ onto a flat, essentially unylelding, horizontal surface, striking 
the surface in a position in which the maximum damage is expected to occur. A full-scale test model was designed and fabricated in ORNL Shops. The model was fabricated in accordance with the ORNL Isotopes Division drawings in Appendix E.

1.5.1.1 End drop (bottom). During July 1971, this full-sized model was drop tested at the ORNL Drop Test Faciltty. The shield was loaded with $2300 \mathrm{lb}$ of lead bricks to simulate an inner Type $A$ or Specification 55 gamma shield. An 8- by 8- by 1-1n.-thick steel plate welded to the drop pad at its geometric center for other testing in progress at this time was not removed, since 1t would effect a more stringent test. The model was dropped from $30 \mathrm{ft}$, impacting on its bottom. The change in length of the package was less than $1 / 4 \mathrm{in}$. The area of the base that contacted the plate was deflected equivalent to the plate thickness of $1 \mathrm{in}$. There was one visible hairline crack about $1 / 4$ in. long in a weld which impacted in the vicinity of the plate. There was no significant damage to the interior due to the bricks nor was there any breach of the outer shell through which any $\mathrm{LiOH} \cdot \mathrm{H}_{2} \mathrm{O}$ could be lost. This test was witnessed by ORNL staff members.

1.5.1.2 End drop (top). If the shield impacted on the top, the four vertical channels would contact the pad (unyielding surface) and collapse. The primary concern in a top impact would be separation of the cover from the base. Note that the maximum allowable weigh. of $2500 \mathrm{lb}$ of an inner shield and contents would place the twenty 1.0-in.diam bolts in tension due to the inertial forces. Calculations to estimate the accelerations experienced in this impact would be suspect. Hence, five half-scale models of the channel section were tested at the ORNL drop tower on April 18, 1974. The test was conducted in accordance with the procedure in Appendix F. The report of this test and the data are also included in Appendix F. The model shown In Figs. 1.4 and 1.5 was bolted to the bottom of the guided, variable-weight drop hammer. A total weight of $121 \mathrm{lb}$ represents a half-scale of one-fourth the total container weight, the portion applicable to one channel.

Five drops from 30 it wise made. Figure 1.6 indicates the typlcal damage to the models. Acceleration with respect to time was measured 
28

PHOTO 0765-74

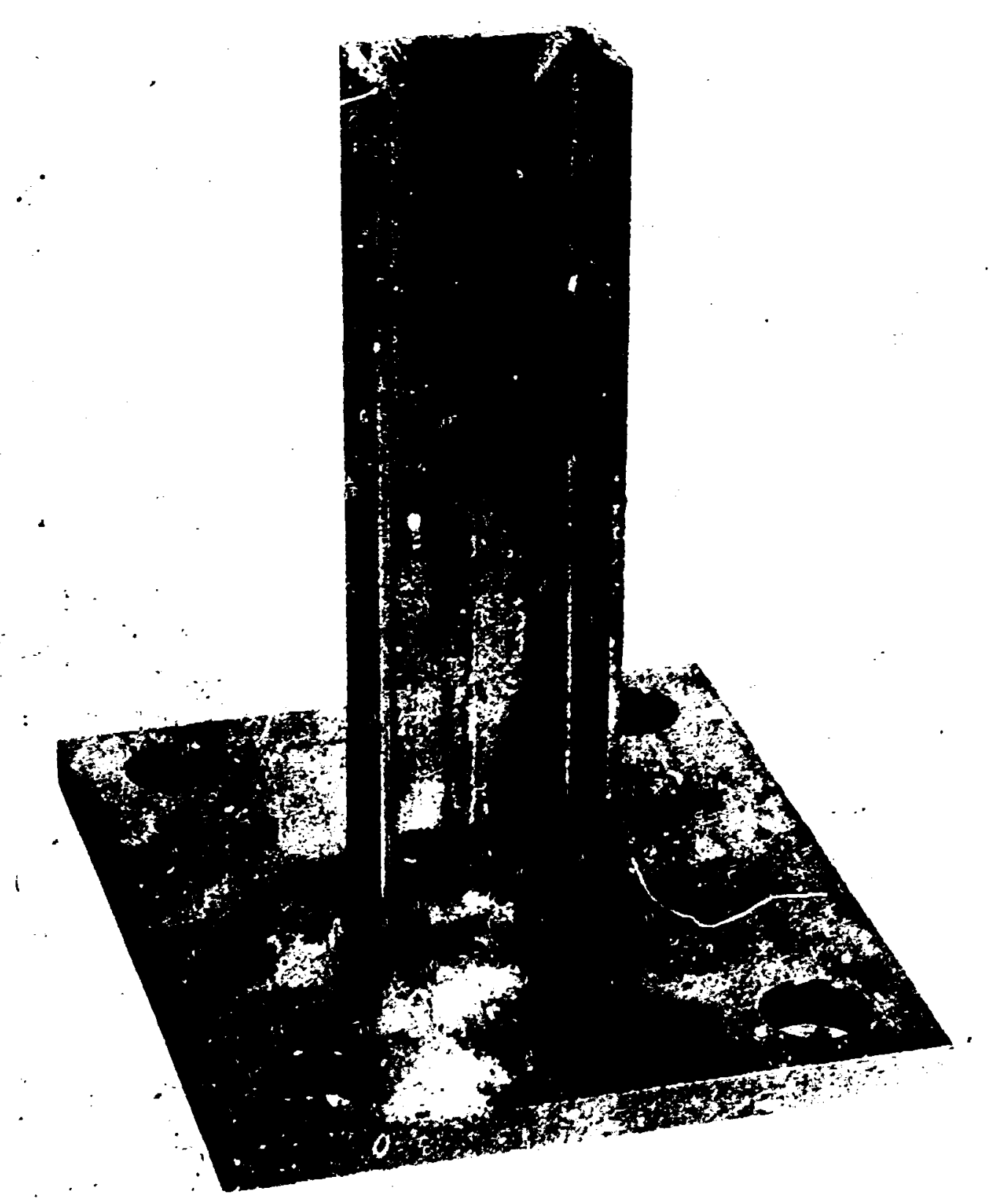

Fig. 1.4. Impact test model. 

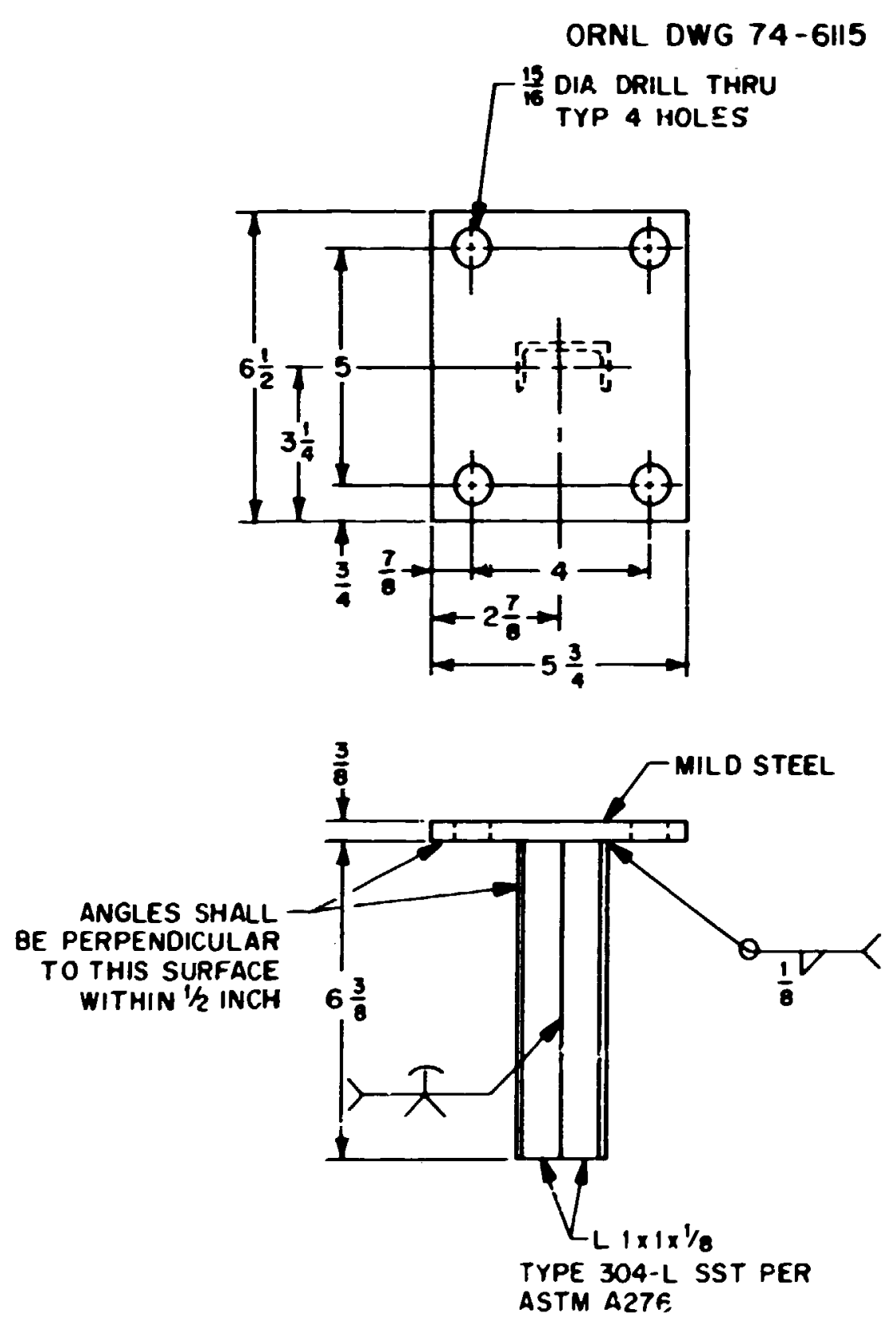

F1g. 1.5. Top impact test model. 


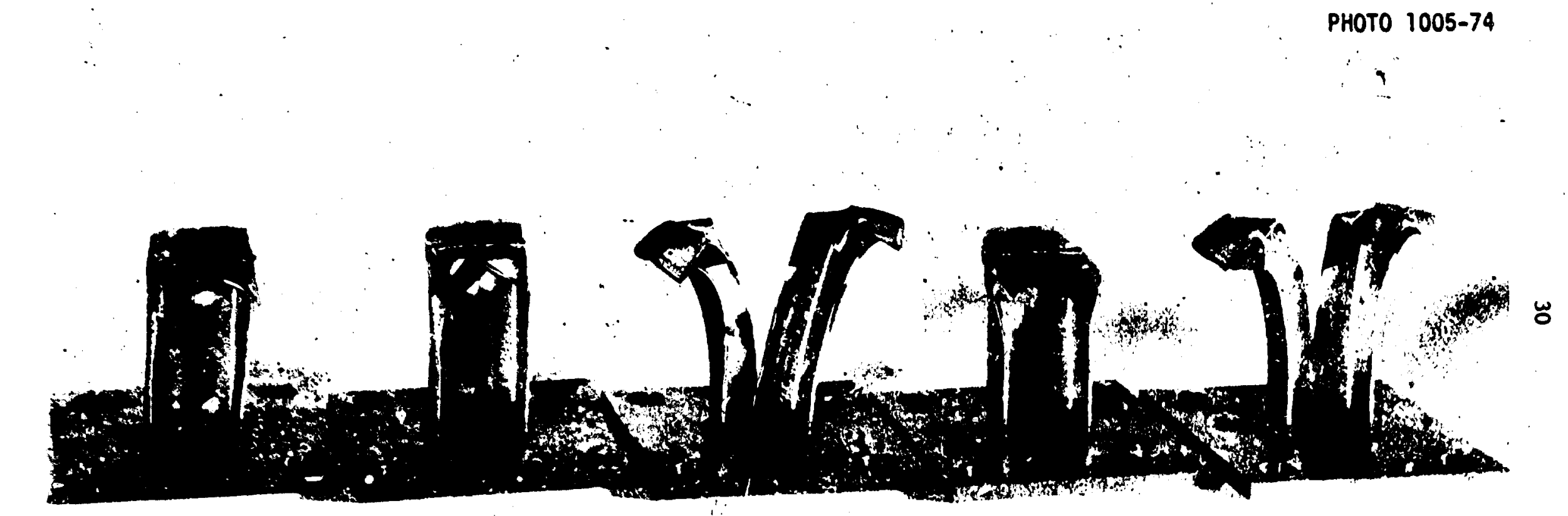

F1g. 1.6. Models after te ting. 
using the instrumentation system shown in Fig. 1.7 and the peak recording accelerometer. From the data in Appendix $F$ it can be seen that the acceleration of the half-scale model did not exceed $200 \mathrm{~g}$ 's. From model theory it can be concluded that the maximum acceleration for the fullsized channel would not exceed cne-half this value, or $100 \mathrm{~g}$ 's, since model theory predicts that accelerations are inversely proportional to scale factor. Hence, for four channels, the shield acceleration would be $100 \mathrm{~g}$ 's. From Newton's second law, the force, F, applied to the bolts can be found from

$$
F=m a-W a / g-(2730)(100)(32.2) / 32.2=273,0001 b,
$$

where

$$
\begin{aligned}
& W=\text { weight of the contents and } l i d=2730 \mathrm{lb}, \\
& a=\text { acceleration }=100 \mathrm{~g} s \\
& \mathrm{~g}=\text { gravitaitional constant }\left(\mathrm{ft} \cdot 1 \mathrm{~b}_{\mathrm{m}} / 1 \mathrm{~b}_{\mathrm{f}} \cdot \mathrm{sec}^{2}\right)
\end{aligned}
$$

Note that this is a conservative approach: it asgumes that the $11 \mathrm{~d}$ and contents are rigid. It follows that the stress is

$$
\sigma=F /(\mathrm{NA})=273,000 /[(20)(0.6051)]=22,600 \mathrm{ps1} \text {, }
$$

where

$$
\begin{aligned}
& N=\text { number of bolts }=20, \\
& A=\text { stress area of one bolt (see ref. 8). }
\end{aligned}
$$

Since this is below the yield stress of the bolts, which 1 s 105,000 psi (see Table. .1 ), it can be concluded that the $11 d$ wll remain in place and that the shield mee:s the requirements of the regulations.

\subsubsection{Impact on side}

The highest level of acceleration would occur if the shield impacted normal to one of the channels. The two legs of the channel would collapse simflarly to heat tiansfer fins with very smsll angles of inclination 


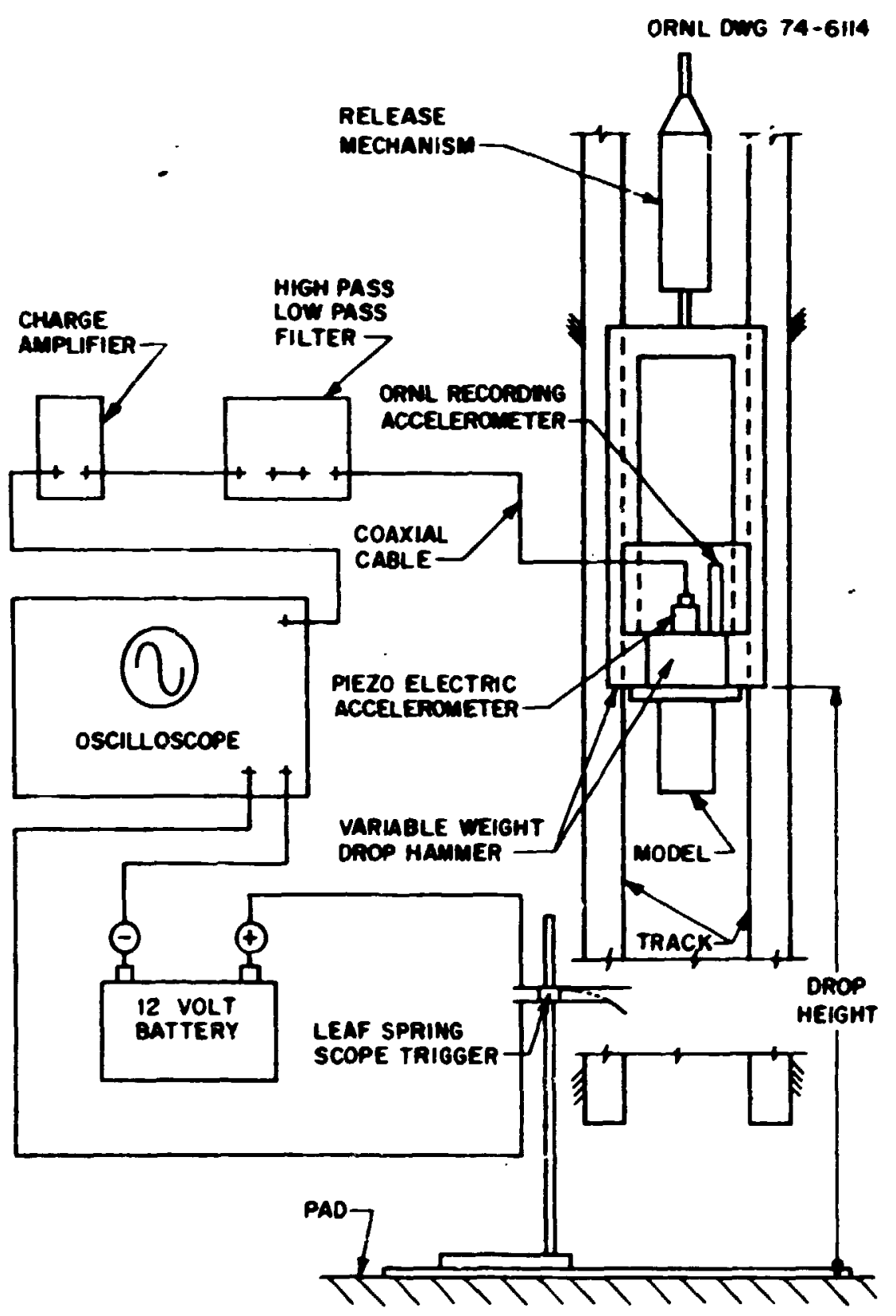

Fig. 1.7. Schematic model testing. 
if the turning moment attributable to the closure flange, which strikes first, is neglected. If the data from Fig. 5.10 from Davis's report 9 on fins is extrapolated slightly, the peak force for a fin having a height-to-thickness ratio uí 8 is found to be about $9.2 \times 10^{4}$ lb per inch of length. Note that Davis's fin models were 2 in. 1ong. It is believed that there is little difference in the peak force for a stainless steel fir. and for the ASTM A285 steel fins Davis tested. This conclusion is supported by static column theory and dynamic tensile stress-strain data by Clark, 10 and is modified to compressive data and presented by Evans. II Static column theory states that the critical collapse load for an intermediate columa, $30<\mathrm{L} / \mathrm{K}<100$, is a function of material yleld strength and $L / K$, where $L=$ effective colum length (in.), and $K=1$ east radius of gyration (in.). The dynamic yield point frow data by clark for both 18-8 stainless steel and mild steel is approximately $60,000 \mathrm{psi}$ at an impact velocity of $40 \mathrm{fps}$.

If the effective length of the channel is taken as 44-1/4 in., the channel length for total $f$ in length of $88-1 / 2$ in., the peak force, $F$, is

$$
F=\left(9.2 \times 10^{4}\right)\left(88.5 j=8.14 \times 10^{6} 1 \mathrm{~b} .\right.
$$

The peak acceleration, a, from Newton's second law is

$$
a=F_{g} / W=\left(8.14 \times 10^{6}\right)(g) / 4000=2040 \mathrm{~g}^{\prime} \mathrm{s} .
$$

Again, from Newt on's law the shearing force, $F_{s}$, on the bclts holding the lid to the base is

$$
F_{s}=W_{L} a / g=(310)(2040)(g) / g=632,0001 b,
$$

where $W_{L}$ is the weight of the $11 \mathrm{~d}=3101 \mathrm{~b}$.

The shearing stress in the twenty l-in. closure bolts is

$$
\tau=F_{S} /\left[(N)\left(A_{B}\right)\right]=632,000 /\left[(20)(\pi)(1)^{2} / 4\right]=40,200 \mathrm{ps} 1,
$$

which is less than the al lowable shear stress of 52,500 psi (see Table 1.1). 
The evaluation of Davis's data (see Appendix B of Davis 's report ${ }^{3}$ ) for straight fins revealed that the ratio, $K$, of the peak or maximum force to the average force was between 1.3 and 3.2 . Using this ratio, it can be written that

$$
U=F_{\text {avg }} \Delta L=F_{\max } L / K=W H,
$$

where

$$
\begin{aligned}
& U=\text { energy }(\text { in. } \cdot 1 b) \text {, } \\
& \Delta=\text { deformation of the fin (in.), } \\
& L=\text { total active length of } f \text { in (In.), } \\
& W=\text { shield weight (1b), } \\
& H=\text { drop helght (in.), } \\
& F_{\text {avg }}=\text { average or mean force required to crush a fin } \\
& \text { per inch of length (1b), } \\
& F_{\max }=\operatorname{maximum} \text { force, that } 18 \text {, force required to start }
\end{aligned}
$$

Solving for $\Delta$ and taking $\mathrm{K}$ as 3.2 for conservatism,

$$
\Delta=(\mathrm{KHH}) /\left(\mathrm{F}_{\max } \mathrm{L}\right)=[(3.2)(4000)(360)] /[(92,000)(61.5)]=0.81 \mathrm{in} .
$$

Since $\Delta$ is less than the 1.75 in. avallable for collapse, it is concluded that the channels have the capacity to absorb the kinetic energy possessed by the package; hence there will not be significant damage to the remainder of the package. Note that only the length of the fin rigidly backed by the shield was taken for L. Also, the stainiess steel fin would have greater energy absorption capacity than a steel fin of the same geometry due to the strain hardening characteristics of stainless steel.

If the shield impacted or. 1ts side in another radial orientation, the closure flange would contact the surface first. There would be some plastic deformation of the flange, and the shield would rotate about the point of contact until the fins at the base contacted the impact surface. The shteld's kinetic energy would be dissipated in plastic 
deformation of the closure flanges, the heat transfer $f$ ins, and the shield body. The response of the shield to this impact cannot be calculated by current techniques. However, it can be seen that the accelerations will be less than those calculated for the impact on the channels. Comparison of the structural rigidity of the channel legs and the closure flanges supports this. The previously referenced tests ${ }^{14}$ of the 4000-1b plaster-filied container also support this and demonstrate that there will not be gross structural failure which would allow loss of $\mathrm{LiOH}$ and that the 1 id will remain in place.

\subsubsection{Puncture}

The second in the sequence of hypothetical accident conditions to which the package must be subjected is a free drop through a distance of 40 in. to strike, in a position in which maximum iamage is expected, the top end of a vertical cylindrical mild steel bar mounted on an essentialiy unyielding, horizontal surfaç. The mild steel bar shall have a diameter of 6 in., with the top horizontal and its edge rounded to a radius of not more than $1 / 4$ in., and the bar shall be of such length that it will cause maximum damage to the package but not less than $8 \mathrm{in}$. long. The long axis of this bar shall be normal to the surface of the package upon Impact.

The full-scale test model described in Sect. 1.5.1.1 and Appendix E was droppec from $40 \mathrm{in}$. onto the bar as described above. The paricage Impacted on the flat botton. There was no puncture of the outer shell. The permanent $(\equiv f$ lection in the piston contact area was minimal, less than $1 / 4 \mathrm{in}$. The flat bottom was a more vulnerable orientation than the fin-protected circumference and essentially equivalent to the flat top. Based on the observed damage, it is concluded that the shield conforms to the requirements of the regulations.

\subsection{Special Form}

The ORNL Operations Division is authorized by Laboratory management to certify that a material conforms to the special form requirements of Annex 4 of MC0529.1 The tests prescribed by Annex 4 have been performed 


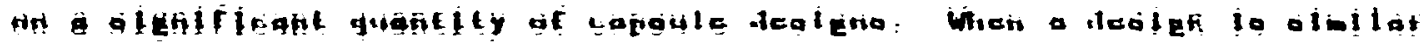

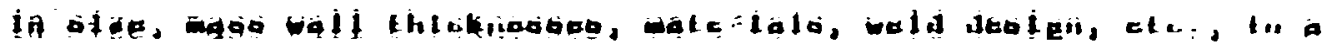

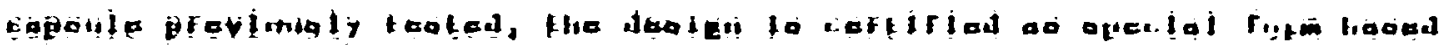

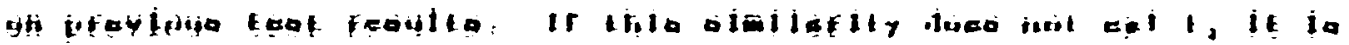

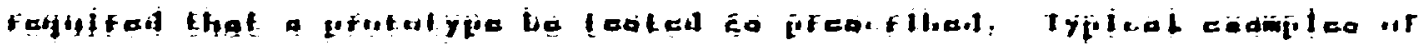

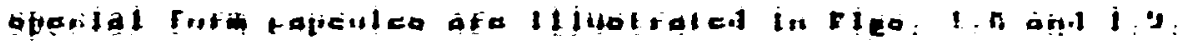

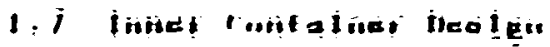

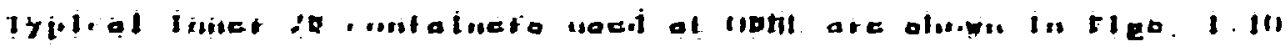

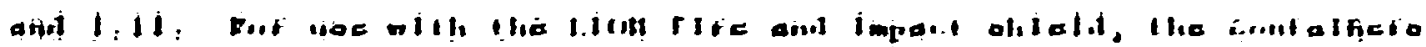

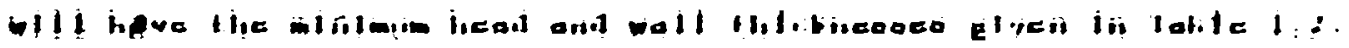

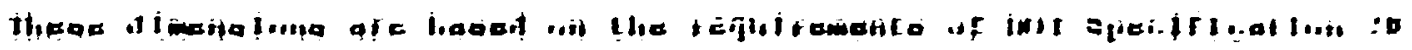

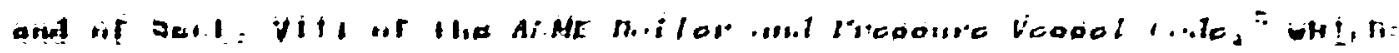

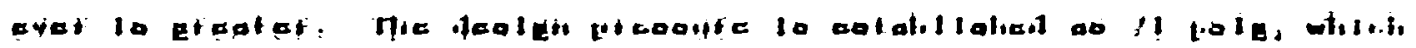

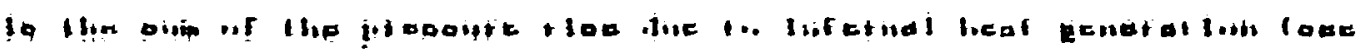

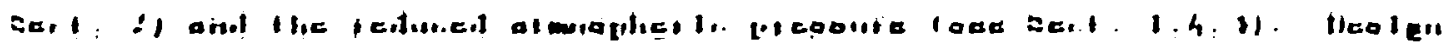

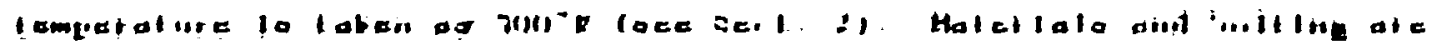

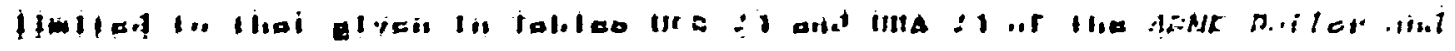

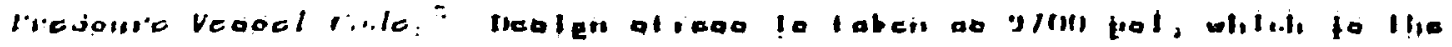

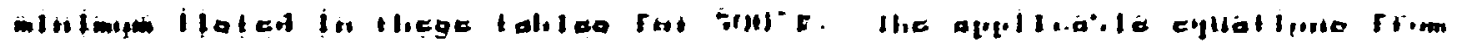

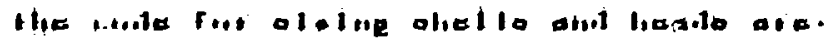

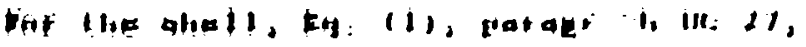

$$
1=P(1=2: \mu \cdot \omega):
$$

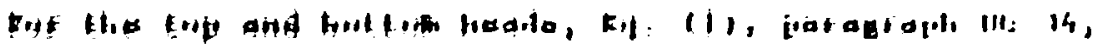

$$
1-n(i+N / 0) 1 /:=
$$

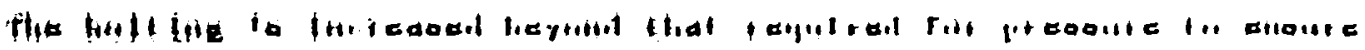

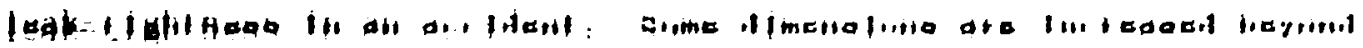

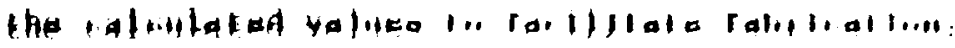


OHNL DWG 74-3853

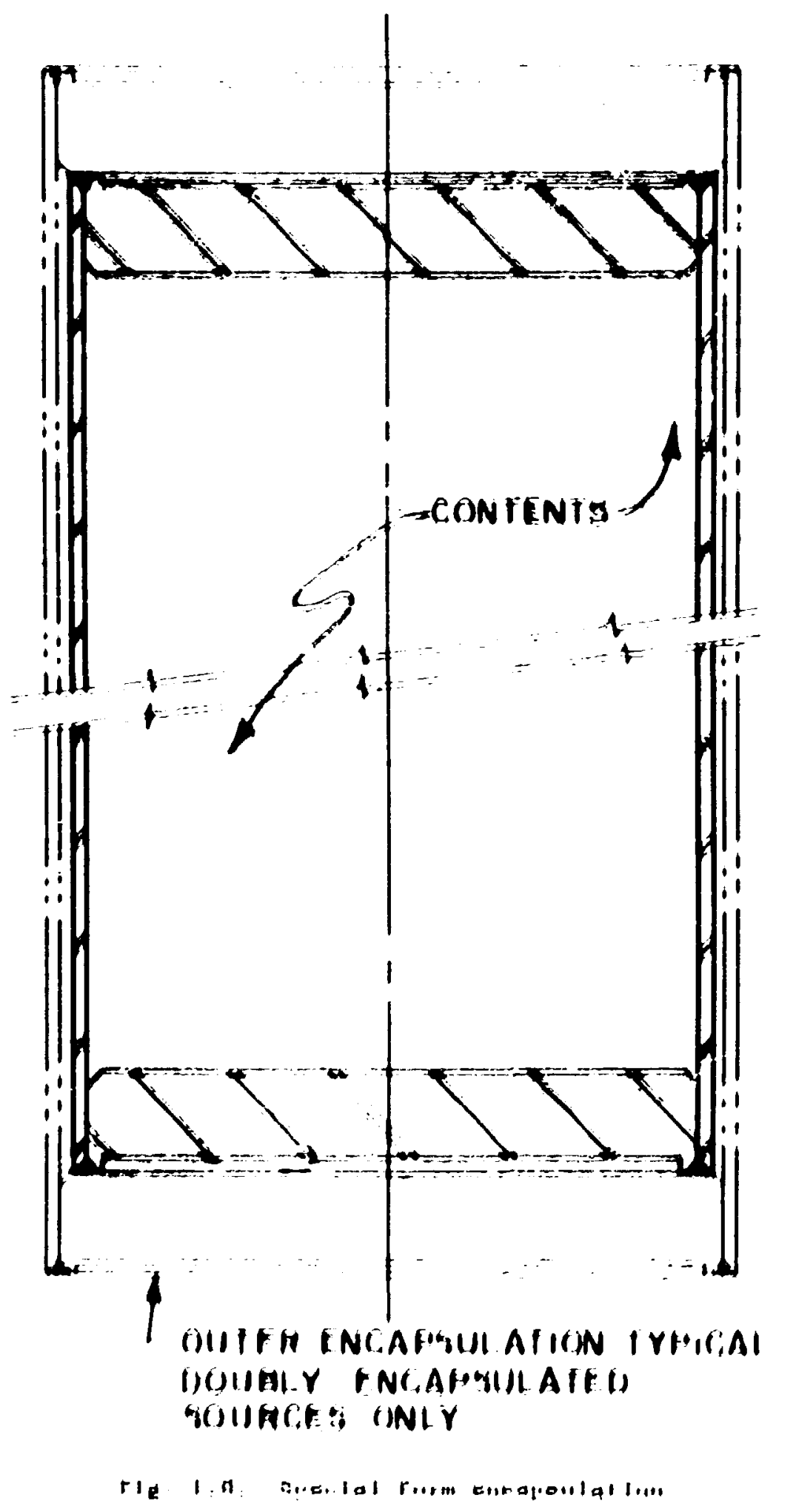


ORNL DWG 74-3856

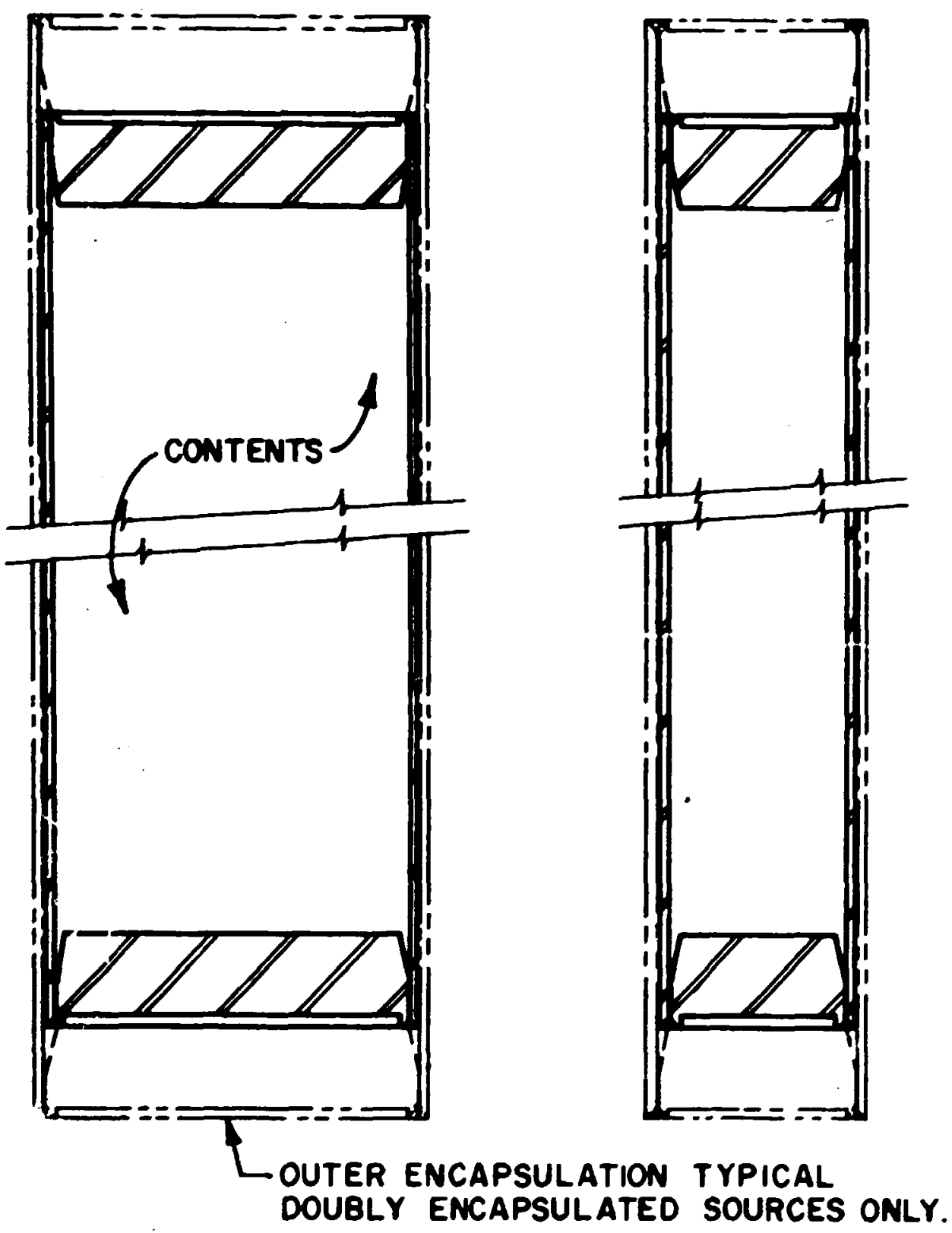

Ffg. 1.9. Special form encapsulation. 


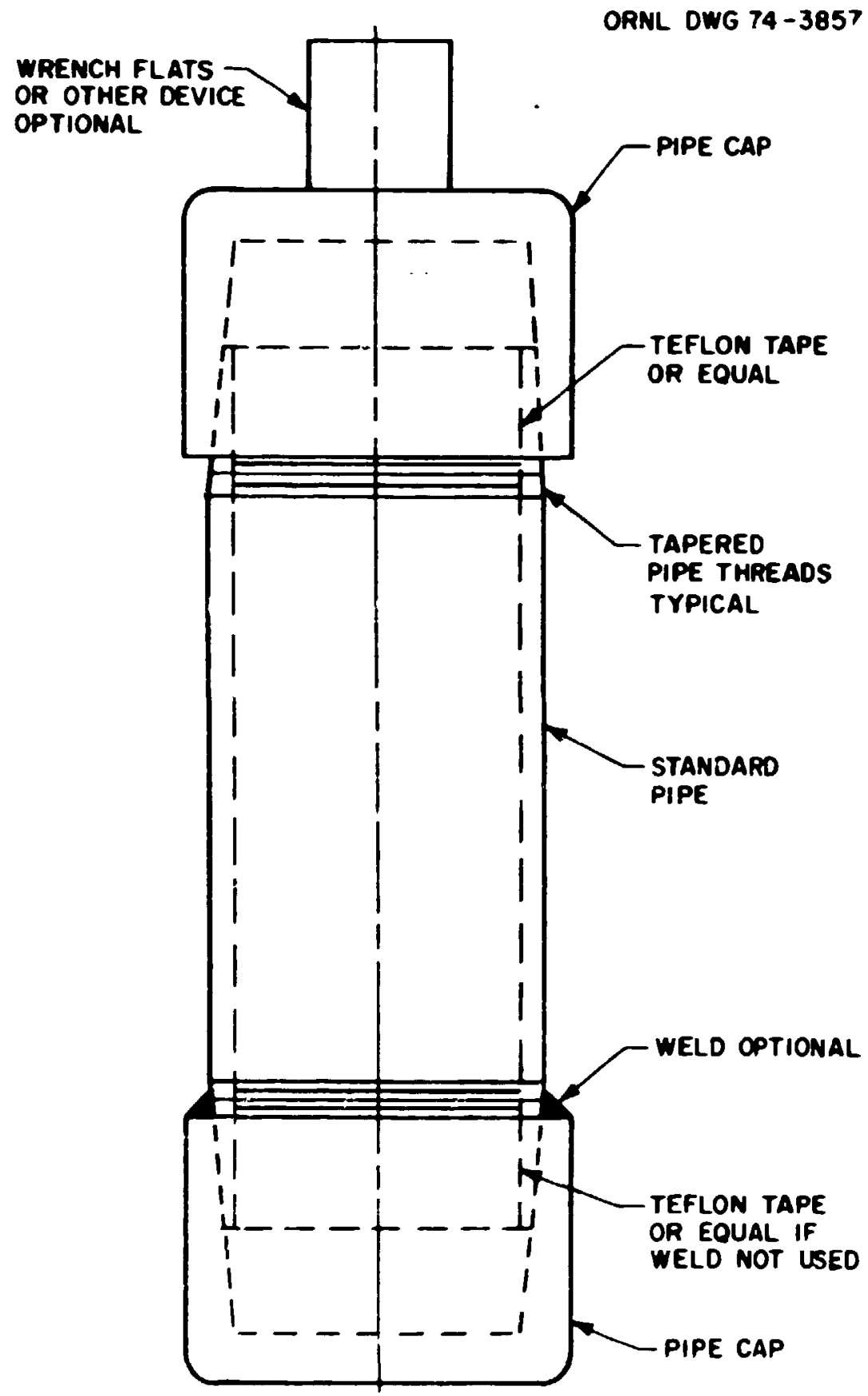

Fig. 1.10. 2R container. 


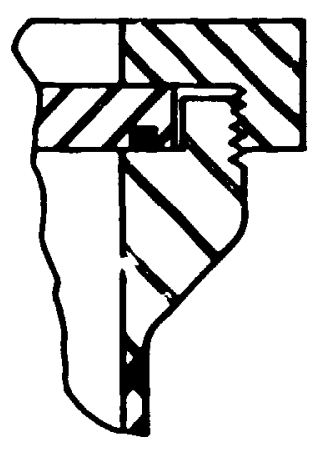

(a)

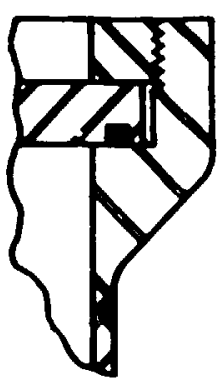

(b)
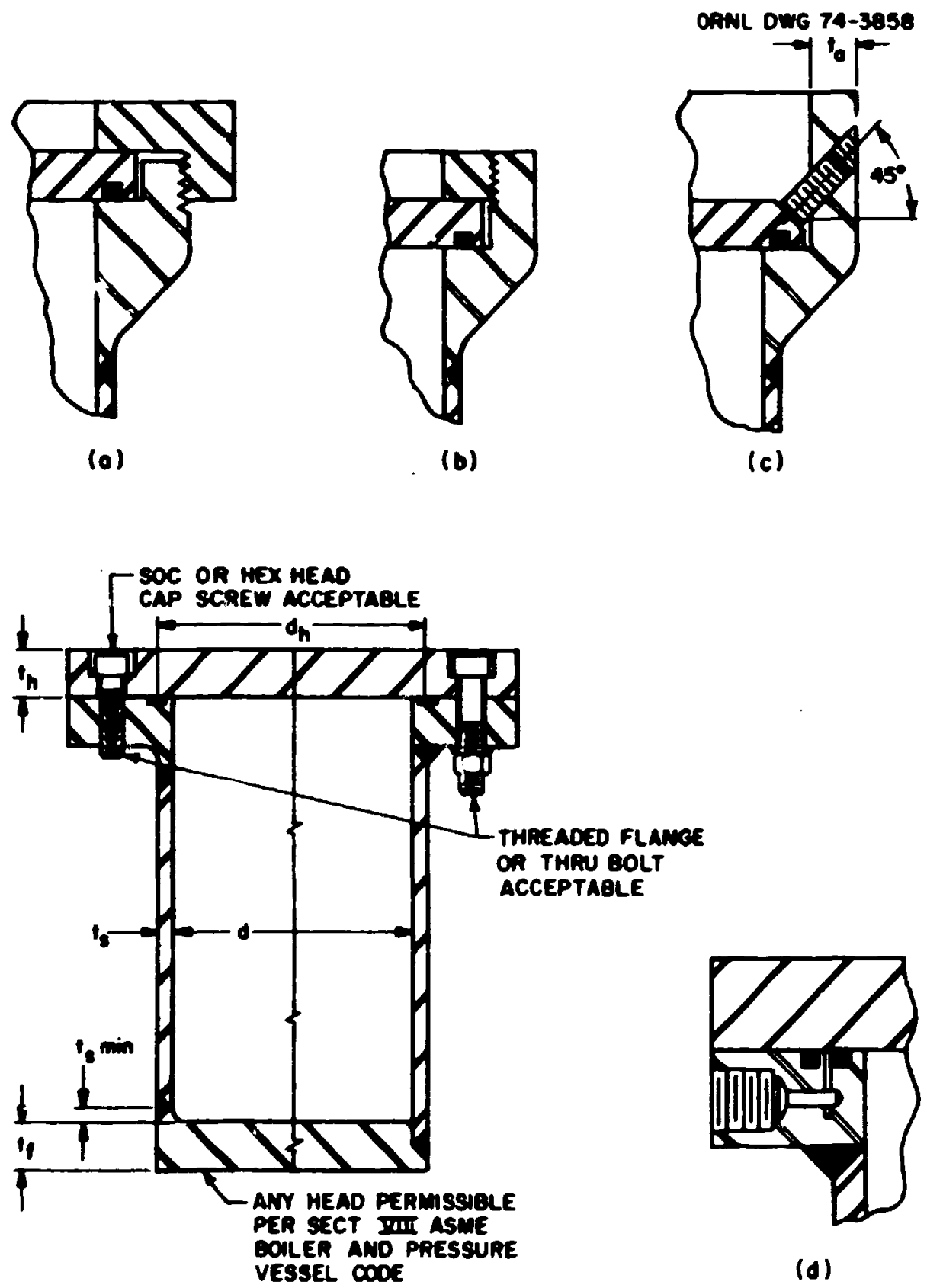

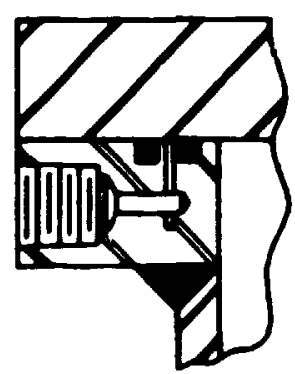

(d)

F18. 1.11. Typical 2R containers. 
Table 1.2. Dimension schedule for $2 R$ specification containers (Fig. 1.11)

\begin{tabular}{cccccccc}
\hline & & & & & \multicolumn{2}{c}{ Bolts } \\
\cline { 7 - 8 } & $t_{s}$ & $t_{f}$ & $t_{h}$ & $t_{s}$ & No. & Size \\
\hline 2 & $3 / 32$ & $3 / 16$ & $3 / 16$ & $3 / 8$ & 4 & $1 / 4-20$ \\
3 & $1 / 8$ & $1 / 4$ & $1 / 4$ & $3 / 8$ & 6 & $1 / 4-20$ \\
4 & $1 / 8$ & $1 / 4$ & $1 / 4$ & $3 / 8$ & 8 & $1 / 4-20$ \\
5 & $1 / 8$ & $1 / 4$ & $1 / 4$ & $3 / 8$ & 8 & $5 / 16-18$ \\
6 & $1 / 8$ & $3 / 8$ & $1 / 4$ & $3 / 8$ & 8 & $5 / 16-18$ \\
8 & $1 / 4$ & $3 / 8$ & $3 / 8$ & $3 / 8$ & 8 & $3 / 8-16$ \\
10 & $1 / 4$ & $1 / 2$ & $3 / 8$ & $1 / 2$ & 12 & $3 / 8-16$ \\
12 & $1 / 4$ & $1 / 2$ & $1 / 2$ & $1 / 2$ & 16 & $3 / 8-16$ \\
\hline
\end{tabular}




\section{THERMAL EVALUATION}

\subsection{Discussion}

The package must be able to withstand direct sunlight at an ambient temperature of $130^{\circ} \mathrm{F}$ in still air without reducing the effectiveness of the packaging. The DOT regulations ${ }^{3}$ further stipulate that the temperature of any accessible surface of tie fully loaded shipping package shall not exceed $122^{\circ} \mathrm{F}$ w en the package is in the shade in still air at an ambient temperature; for this evaluation, ambient temperature was assureed to be $100^{\circ} \mathrm{F}$.

The third in the sequence of hypothetical accident conditions to which the cask must be subjected, as specified by the regulations, is exfosure for 30 min within a source of radiant heat having a temperature of $1475^{\circ} \mathrm{F}$ and an emissivity coefficient of 0.9 or equivalent. For caliulational purposes, it shall be assumed that the package has an absorption coefficient of $\mathbf{0 . 8}$. The parkage shall not be cooled artifically until ater the 30-min test period has expired and the temperature at the center of the package has begun to fall.

A computer program, HEATING-3, ${ }^{7}$ was used to determine the temperature distribution and the quantity and location of material which changes phase when the cask is exposed to these thermal enviroments.

It was assumed that the container was loaded with the maximum permissible decay heat load of $300 \mathrm{~W}$. The temperature distribution from $100^{\circ} \mathrm{F}$ amblent condition was input a starting temperatures for the accident (fire) calcilation.

\subsection{Thermal Properties of Materials}

The thermal properties of materials used to compute the temperature distribution and material phase change are listed in Table 2.1.

\subsection{Thermal Evaluation for Normal Conditions of Transport}

\subsubsection{Thermal model}

The computational model representing the $\mathrm{LHOH}$ shield and its intended contents is illustrated in Fig. 2.1. The contents are modeled 
Table 2.1. Materlal properties used in thermal analysis

\begin{tabular}{|c|c|c|c|c|c|}
\hline & $\begin{array}{l}\text { Temperature } \\
\left({ }^{\circ} \mathrm{F}\right)\end{array}$ & $\begin{array}{l}\text { Thermal conductivlty } \\
\left(\mathrm{Btu} / \mathrm{hr} \cdot \mathrm{ft} \cdot{ }^{\circ} \mathrm{F}\right)\end{array}$ & $\begin{array}{l}\text { Density } \\
\left(1 \mathrm{~b} / \mathrm{In}^{3}\right)\end{array}$ & $\begin{array}{l}\text { Heat capacity } \\
\left(\mathrm{Btu} / 1 \mathrm{~b} \cdot{ }^{\circ} \mathrm{F}\right)\end{array}$ & $\begin{array}{l}\text { Latent heat } \\
(\mathrm{Btu} / \mathrm{Lb})\end{array}$ \\
\hline $\begin{array}{l}\text { Hydrated } 11 \text { th } f \text { um } \\
\text { hydroxide } a, b, c\end{array}$ & 212 & 0.316 & 0.031 & 0.661 & 560 \\
\hline $\begin{array}{l}\text { Dehydrated lithium } \\
\text { hydroxide } a, b\end{array}$ & & 0.2576 & 0.0243 & 0.356 & \\
\hline Stainless steol & $\begin{array}{r}32 \\
212 \\
752 \\
932 \\
1292\end{array}$ & $\begin{array}{l}7.73-8.51 \\
9.43 \\
12.57 \\
14.99\end{array}$ & 0.2861 & $\begin{array}{l}0.120 \\
0.135\end{array}$ & \\
\hline $\operatorname{Lead}^{2},:^{2}$ & $\begin{array}{r}32 \\
572 \\
621\end{array}$ & $\begin{array}{l}20.3 \\
17.2\end{array}$ & 0.41088 & $\begin{array}{l}0.0305 \\
0.03282\end{array}$ & \\
\hline Plywood" & & 0.1 & 0.0347 & 0.1 & \\
\hline
\end{tabular}

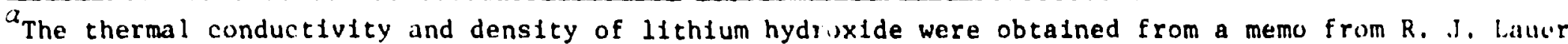
to R. D. Seagren, "Monthly Report for June 1969," dated June 27, 1969 (see Append1x J).

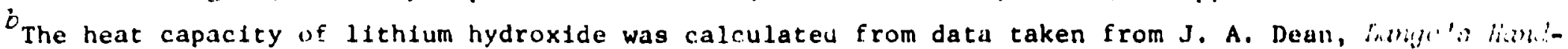
book of Chemistry, McGraw-Hill, New Yurk, 1973.

The latent heat of hydrated lithluin hydroxide $\left(\mathrm{L} 1 \mathrm{OH} \cdot \mathrm{H}_{2} \mathrm{O}\right)$ was based upon the weight fraction of watcr.

$l^{\prime}$ The properties of stainless steel were obtained from $A$ Compization of Thermal Property liata jol Compucer Hect-conduntion cibiculations, UCRL-50589.

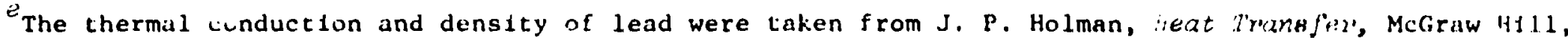
New York, 1972.

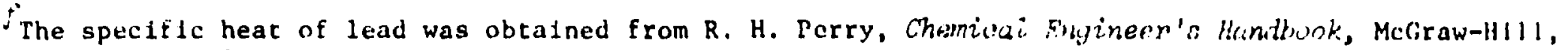
New York, 1973.

The thermal properties of plywood were based upon an engineering estimation. 


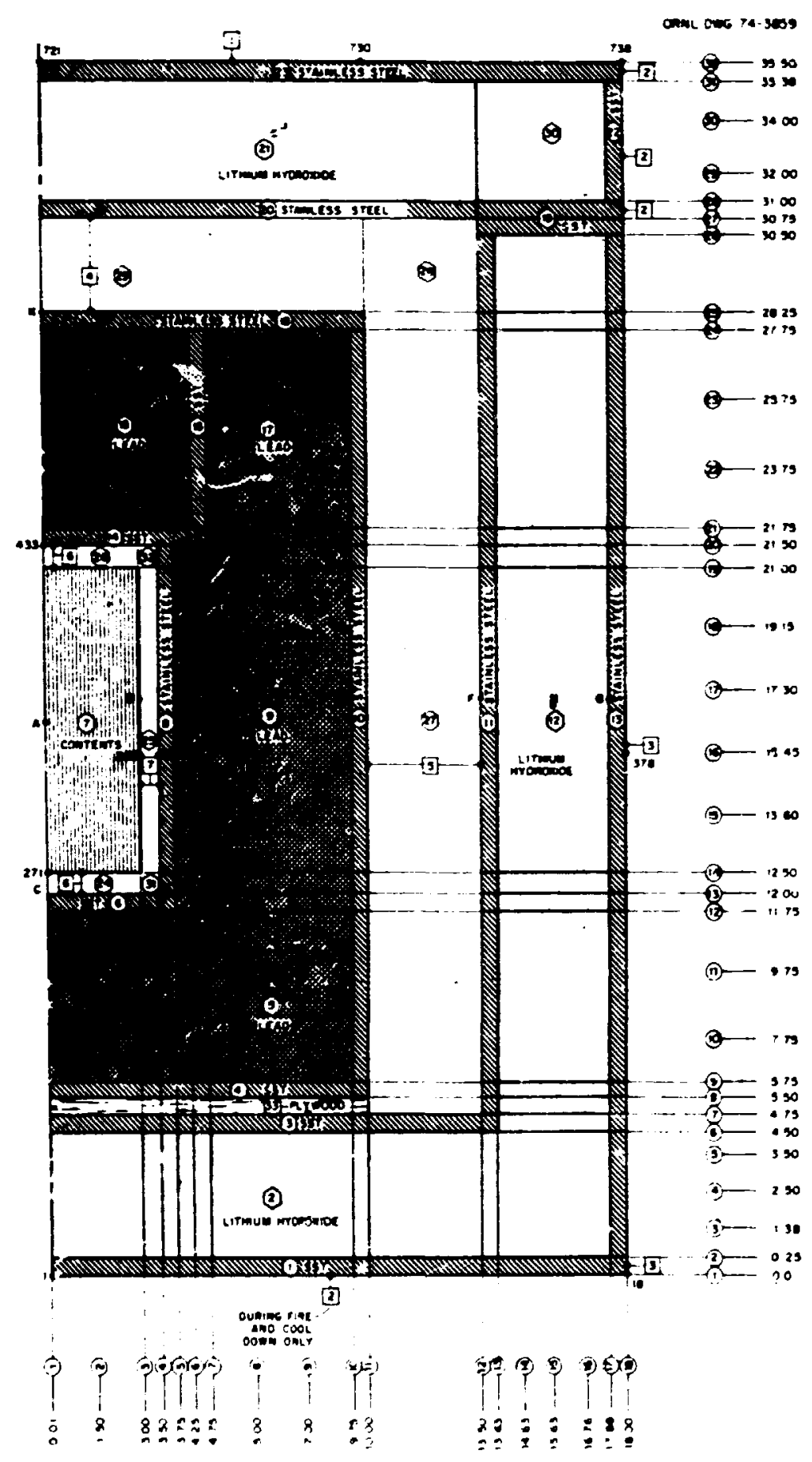

Fig. 2.1. Thermal model. 
as a homogeneous body. The decay heat generation was modeled as being uniformly distributed in the contents. The heat generation rate is assumed to be constant with no decay with time. The conter.s are separated from the inner container by an air gap as shown. This was done, since the contents will be supported in a rack which has rinimum contact. The dimensions of the model of the inner container are typical of the largest containers used. $T$ : 2 base of the cask was assumed to be insulated usuring normal conditions. In actual practice the contents will vary considerably. An inner shielded container will not always be used. If an inner container is not used, there wili be less resistance to heat flow during normal conditions than for the case considered due to Increased transfer by convection and removal of the radiation baffles and air gaps associated with the inner shielded container. The configuration or size of the irner shield has very little effect on contents temperature during the spectfied ihermal exposure (fire) due to evaporative cooling from the loss of water from the lithium hydroxide. The efficiercy of the fins was calcilated, and the heat transfer coefficient for the outer surface was raised t.o compensite for the exclusion of the fins from the model. These calculations, using oquations from Krith, 13 are shown below:

$$
K=[\tanh (m L)] / m L,
$$

where

$$
\begin{aligned}
& \mathrm{E}=\mathrm{f} \text { in effectiveness, } \\
& \mathrm{L}=\mathrm{f} \text { in } \mathrm{h} \in \mathrm{ght}=1 \mathrm{in} .=0.0833 \mathrm{ft}, \\
& \mathrm{m}=(\mathrm{hc} / \mathrm{KA})^{1 / 2},
\end{aligned}
$$

in which

$$
\begin{aligned}
h= & \text { prevalling convective heat transfer coefficient }\left(B t u / h r \cdot \mathrm{ft}^{2} \cdot{ }^{\circ} \mathrm{F}\right), \\
\mathrm{c}= & \text { fin perimeter }=2 \mathrm{in} .=0.167 \mathrm{ft}, \\
\mathrm{K}= & \text { fitted thermal conductivity of stainless steel (see Table } 2.1) \\
= & 7.350+1.23 \times 10^{-2} \mathrm{~T}-1.3 \times 10^{-5} \mathrm{~T}^{2}+6.22 \times 10^{-0} \cdot \mathrm{T}^{3} \\
& \left(\mathrm{Btu} / \mathrm{hr} \cdot \mathrm{ft} \cdot{ }^{\circ} \mathrm{F}\right), \\
\mathrm{A}= & \text { profile area }=1 / 8 \mathrm{in} .^{2}=0.00087 \mathrm{ft}^{2} .
\end{aligned}
$$


The convective heat trausfer coefficient, $h$, was based upon a laminar natural convection correlation for vertical cylinders. A least-squares fit was made to incorporate the temperature dependence of $h$ and $\mathrm{K}$ at an

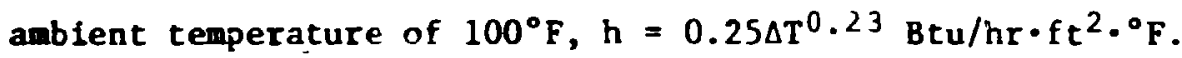

The factor, $F$, by which $h$ is increased to obtain the effect of the fins is

$$
F=\left(A_{b}+A_{F} E\right) / A_{b} \text {, }
$$

where

$$
\begin{aligned}
& A_{b}=\text { base area }=\pi D H=\pi(36)(30.5)=3450 \text { in. }{ }^{2}, \\
& A_{F}=\text { fin area }=H N(2 i+t)=92(30.5)[2(1)+0.125]=5960 \text { in. }^{2},
\end{aligned}
$$

in which

$$
\begin{aligned}
& N=\text { number of } \mathrm{f} \text { ins }=92, \\
& \mathrm{H}=\mathrm{f} \text { in length }=30.5 \mathrm{in.}, \\
& \mathrm{t}=\mathrm{f} \text { in thickness }=0.125 \text { in. }
\end{aligned}
$$

Thus, the effective heat transfer coefficient can be calculated from

$$
h_{e}=\left(0.25 \Delta \mathrm{T}^{0.23}\right) \mathrm{FBtu} / \mathrm{hr} \cdot \mathrm{ft}^{2} \cdot{ }^{\circ} \mathrm{F}
$$

The effective surface emissivity for the finned area of the cask was calculated using the equations in the Cask Designer's Guide for a cavity-type radiator. The surface emissivity was assumed to be 0.6. The effective emissivity was found to be 0.81 .

After the above results (Table 2.2) were calculated, region 24 (Fig. 2.i) was changed from air to stainless steel to simulate an inner container which would always contact the bottom of the shielded container. This also simulates the effect of a concentrated reat source. Results indicated there were only minor differences in temperature distribution.

Finally, the $2 R$ container was assured to be suspended in the fire shield cavity (see Fig. 2.2). Although this is not a realistic possibility, it serves as a conservative case. Results indicated a higher cemperature (Table 2.2) for the concents, with a minor change in surface temperatures. 
Table 2.2. Package temperatures during normal conditions of transport

\begin{tabular}{|c|c|c|c|c|}
\hline \multirow{2}{*}{\multicolumn{2}{|c|}{ Location ${ }^{a}$}} & \multicolumn{3}{|c|}{ Temperature $\left({ }^{\circ} \mathrm{F}\right)$} \\
\hline & & $\begin{array}{l}130^{\circ} \mathrm{F} \text { air } \\
\text { in sunlight }\end{array}$ & $\begin{array}{l}100^{\circ} \mathrm{F} \text { atr } \\
\text { in shade }\end{array}$ & $\begin{array}{c}100^{\circ} \mathrm{F} \text { air } \\
\text { in shade } \\
\text { (suspended } 2 \mathrm{R} \text { container) }\end{array}$ \\
\hline A. & Contents at centerline & 530 & 500 & 680 \\
\hline B. & Contents at midpoint and outer radius & 520 & 490 & 670 \\
\hline C. & Inner container at bottom on centerline & 280 & 220 & \\
\hline D. & $\begin{array}{l}\text { Mid-elevation inner container inner } \\
\text { radius }\end{array}$ & 280 & 220 & \\
\hline E. & $\begin{array}{l}\text { Mid-elevation inner container outer } \\
\text { radius }\end{array}$ & 270 & 220 & \\
\hline F. & $\begin{array}{l}\text { Mid-elevation lioH shleld at inside } \\
\text { radlus }\end{array}$ & 220 & 160 & 200 \\
\hline G. & $\begin{array}{l}\text { Mid-elevation LiOH shield at outside } \\
\text { radius }\end{array}$ & 170 & 115 & 120 \\
\hline H. & Air temperature LiOH cavity & 180 & 150 & 160 \\
\hline I. & Inner container seal & 2.0 & 220 & \\
\hline $\mathbf{J}$ & Cavity LiOH cap & 220 & 140 & 120 \\
\hline K. & Inner container at top on centerline & 200 & 150 & 130 \\
\hline L. & Air in $2 R$ contalner & 400 & 350 & 600 \\
\hline
\end{tabular}

asee Fig. 2.1 for location. 
ORNL OWG 75-12968

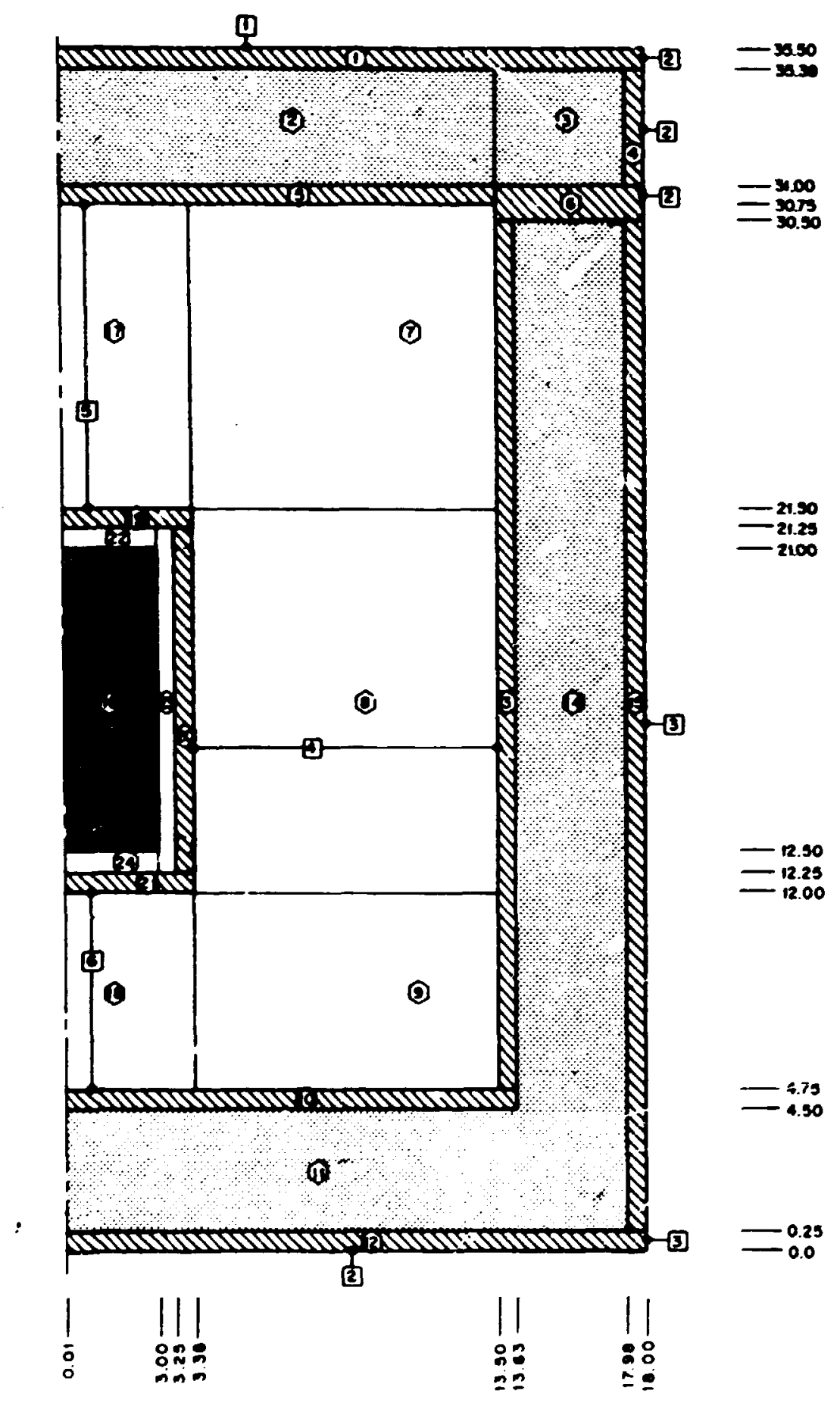

Fig. 2.2. Thermal mode1 - suspended $2 \mathrm{R}$ container. 


\subsubsection{Maximum temperatures}

The maximum cemperatures for the model illustrated in Fig. 2.1 for the environment of $130^{\circ} \mathrm{F}$ in direct sunlight, with a 300- $h$ load, are presented in Table 2.2. It is as:umed that a solar heat flux oi 144 $\mathrm{Btu} / \mathrm{hr} \cdot \mathrm{ft}^{2}$ was incident on the cask. This value of solar heat flux is the value suggested in the Casi Desigrer's Guide. ${ }^{10}$ For the $100^{\circ} \mathrm{F}$ in the shade environment, the maximum accessible surface temperatures were $115^{\circ} \mathrm{F}$ at the midpoint and $110^{\circ} \mathrm{F}$ near .e end on the cylindrical portion of the shield. Since this is less than $122^{\circ} \mathrm{F}$, the package complies with the DOT surface temperature regulation cited in Sect. 2.1.

\subsubsection{Minfmum temperatures}

Reduced (iess than $300 \mathrm{~W}$ ) or zero heat loads would lower temperatures throughout the container. This situation would not affect the safe operation of the container nor the margin of safety (see Sect. 1.4.2).

\subsubsection{Maximum internal pressure}

A sealing temperature of $70^{\circ} \mathrm{F}$ is assumed. Thus, for the $130^{\circ} \mathrm{F}$ condition, there would be a $r$ ise in pressure in the encapsulated contents, the inner container, the $\mathrm{LiOH} \cdot \mathrm{H}_{2} \mathrm{O}$ cavities, and, if used, the $2 \mathrm{R}$ container. The resulting pressures are calculated from the gas laws, assuming consitant volume and a sealing temperature of $T_{1}$ of $70^{\circ} \mathrm{F}$ $\left(530^{\circ} \mathrm{R}\right)$ :

$$
\mathrm{P}_{2}=\mathrm{P}_{1} \mathrm{~T}_{2} / \mathrm{T}_{1}
$$

for the $\mathrm{LiOH} \cdot \mathrm{H}_{2} \mathrm{O}$ cavity shield cap,

$$
P_{2}=(14.7)(680) / 530=18.9 \text { psia }=4.2 \text { psig; }
$$

and for the $2 R$ container,

$$
P_{2}=(14.7)(860) / 530=23.9 \text { psia }=9.2 \mathrm{psig} .
$$


For the cask cavity,

$$
P_{2}=(14.7)(706) / 530=19.6 \text { psia }=4.9 \text { psig; }
$$

and for the $\mathrm{LiOH} \cdot \mathrm{H}_{2} \mathrm{O}$ cavity,

$$
P_{2}=(14.7)(657) / 530=18.2 \text { psia }=3.5 \text { psig. }
$$

\subsubsection{Thermal stress}

There are no thermal gradients sufficient to cause significant thermal stress:s in metal ic members.

\subsection{Hypothetical Thermal Accident Evaluation}

The damage from the free-drop and puncture portions of the $r:$ pothetical accident would not adversely affect the performance of the shield in the hypothetical thermal accident. Hence the undaraged configuration was assumed.

\subsubsection{Fire testing}

A full-sized model of the shield as detalled on the drawings (see Appendix E) was fire tested as described below. The lithium hydroxide cavities were vented via $: / 2-i n$.-diaw vent holes ${ }^{15}$ for fire testing as shown on the drawings.

The fire test was carried out at the Dak Ridge Gaseous Diffusion Plant (ORGDP) fire test site. One hundred fifty gallons of diesel fuel was pumped into the outer tank, 100 gal into the middle tank, and 55 gal into the center tank. This was in accordance with normal fire test operating methods at the ORGD? fire rest facility. Water was added to each tank to bring the ofl level up to within $10 \mathrm{in.}$ of the ralls on which the shield rested.

The oil was ignited at 10:49 AM on July 23, 1971. Five minutes after oil ignition, cracking noises were heard. The cracking notse increased in frequency and continued until about 11:20 AM. At 11:15 AM 
it was possible to observe the package momentarily from time to time. Steam sas issuing from the vents in the $11 d_{y}$ and steam appeared to be ventir.g from one side of the package.

There was complete flame coverage until 11:25 AM (30 min) and partia: flame coverage for an additional 10 to 15 min before the fire self-exting:ished. Steam was still issuing from the lid when the fire went out.

Examination of the stield showed that the cracking noise was the popping of the almost dry $\mathrm{LiOH}$ being forced out of the vents by the steam inside. Evidently, LiOH would build up over the vent holes and would be blown out. There was $\mathrm{LiOH}$ spattered over a radius of $10 \mathrm{ft}$ around the shield. The shield itself was covered with spattered LiOH. It was estimated that no more than 2 to $3 \mathrm{lb}$ of $\mathrm{LiOH}$ was logt. The loss was nor. considered significant.

Examination of the inside of the shield showed no apparent damage. The stainless steel was still shiny, with no evidence of heat tinting. The stenciled heat number and ASTM specification number on the inner clading were intact and showed no evidence of being heared. The lead bricks, loaded into the shield to simulate a shielded container and contents, were also intact.

\subsubsection{Thermal accident analysis}

The computational mojel previously used (see Sect. 2.3.1 and Fig. 2.1) to represent the package was assumed for the thermal analysis. The HEATING-3 computer program ${ }^{7}$ was used to determine the temperature distribution in the package that would result from the prescribed $30-m i n$ thermal exposure, and the material constants given in Table 2.1 were used as computer input. The thermal conductivity of hydrated lithfum hydroxide was used in the thermal analysis throughout the $30-m i n$ thermal exposure, with the water of hydration being driven off at $212^{\circ} \mathrm{F}$. This is a conservative assumption, since the thermal conductivity of hydrated lithium hydroxide is greater than the thermal conducivity for unhydrated lithium hydroxide. During the subsequent cooldown the thermal conductivity of unhydrated lithium hydroxide was used in the thermal analysis. 
The steady-state temperature distribution computed for the heat condition of $100^{\circ} \mathrm{F}$ ambience for normal transport and a heat load of $300 \mathrm{~W}$ was taken as the starting point; internal heat generation was also included in the transient analysis. During the 30-min thermal exposure and subsequent cooldown, the base of the cask was exposed to the ambient environment.

\subsubsection{Container temporatures}

The tamperature distribution within the shield with respect to time is illustrated in Figs. 2.3 and 2.4. The interior of the fire shield does not exceed $240^{\circ} \mathrm{F}$ at any time; hence the contents would not exceed the special form test temperature of Annex 4 of MC0529, Part IV.

\subsubsection{Maximum pressures}

The resulting pressure for the cask cavity is

$$
P_{2}=P_{1} T_{2} ! T_{1}=(14.7)(700) / 530=19.4 \text { psia }=4.7 \mathrm{psig} \text {, }
$$

and for the $2 R$ container

$$
P_{2}=P_{1} T_{2} / T_{1}=(14.7)(825) / 530=22.9 \text { psia }=8.2 \mathrm{psig} ;
$$

these pressures are negligible.

The $\mathrm{LiOH} \cdot \mathrm{h}_{2} \mathrm{O}$ cavities are equipped with fusible plugs so that they will be vented during a fire.

\subsubsection{Evaluation of package performance}

The temperatures and pressures resulting from the specified thermal exposure will not result in the release of radioactive material, increase In radiation dose beyond permissible 1imits, or nuclear criticalfty. Both the special form encapsulation and the $2 R$ contalner vill maintain coniainment of contents. No lead will melt within the inner container. The $\mathrm{L} 1 \mathrm{OH} \cdot \mathrm{H}_{2} \mathrm{O}$ will lose moisture (hydrogen content) as 11lustrated in Fig. 2.5. The resulting increase in neutron dose will not exceed the speciffed limits (Sect. 4). 
-IOH SHIPPING CASK FIRE TEST

OANL OUG $77-3 ! ! S$

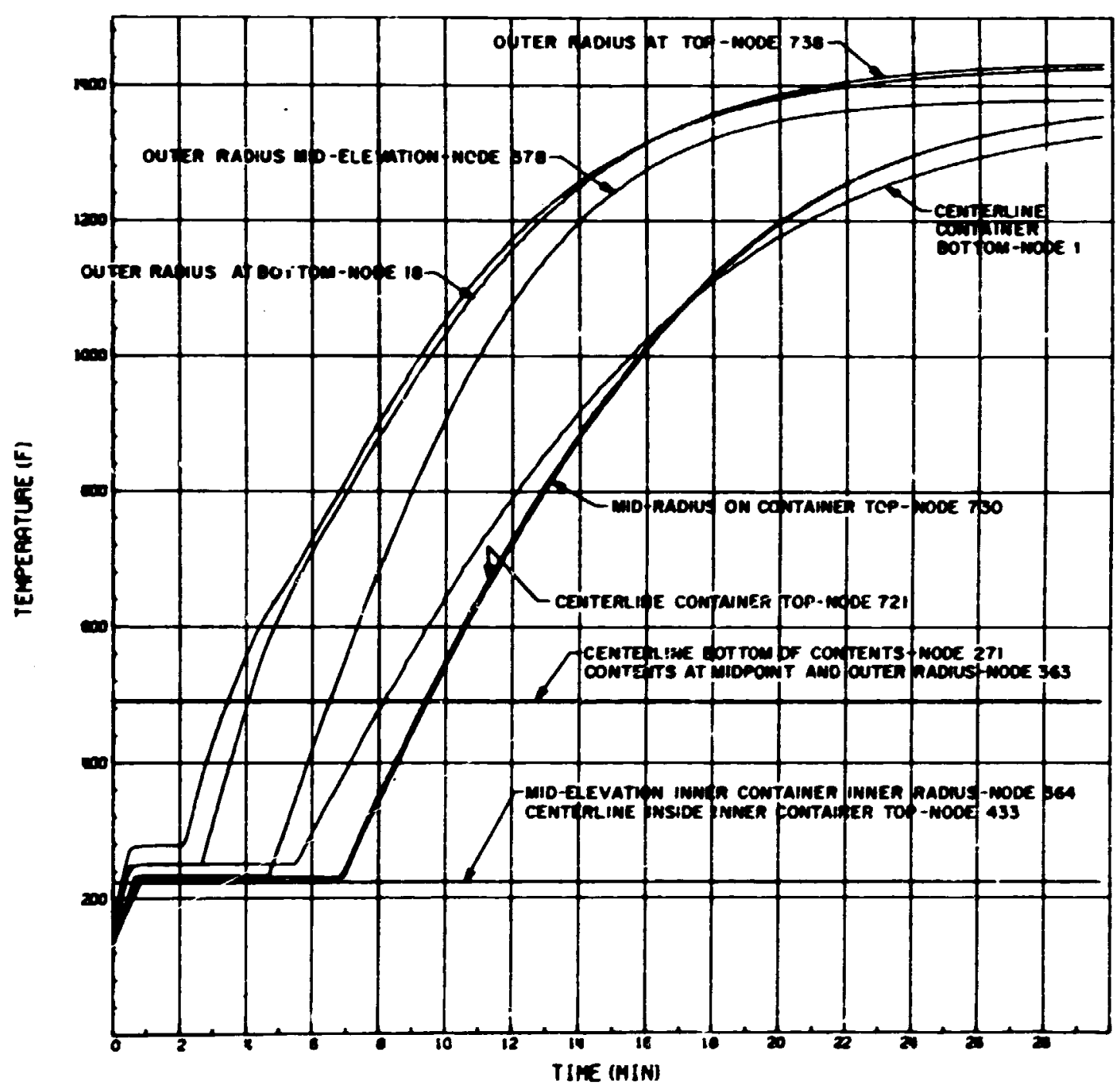

F1g. 2.3. Temperature-time history for cask fire test. 


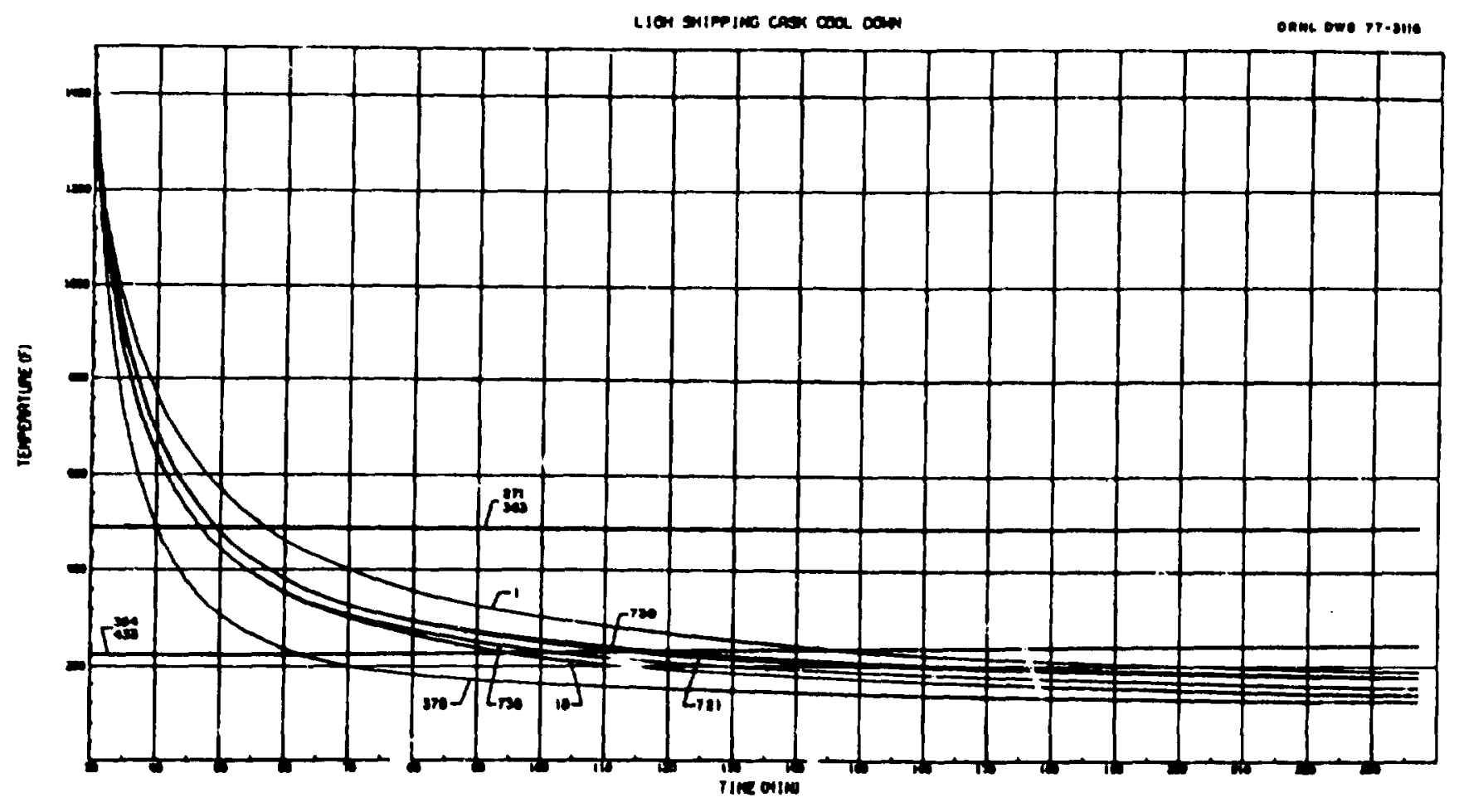

Fig. 2.4. Temperature-time history for cask cooldown (see Fig. 2.3 for node identification). 


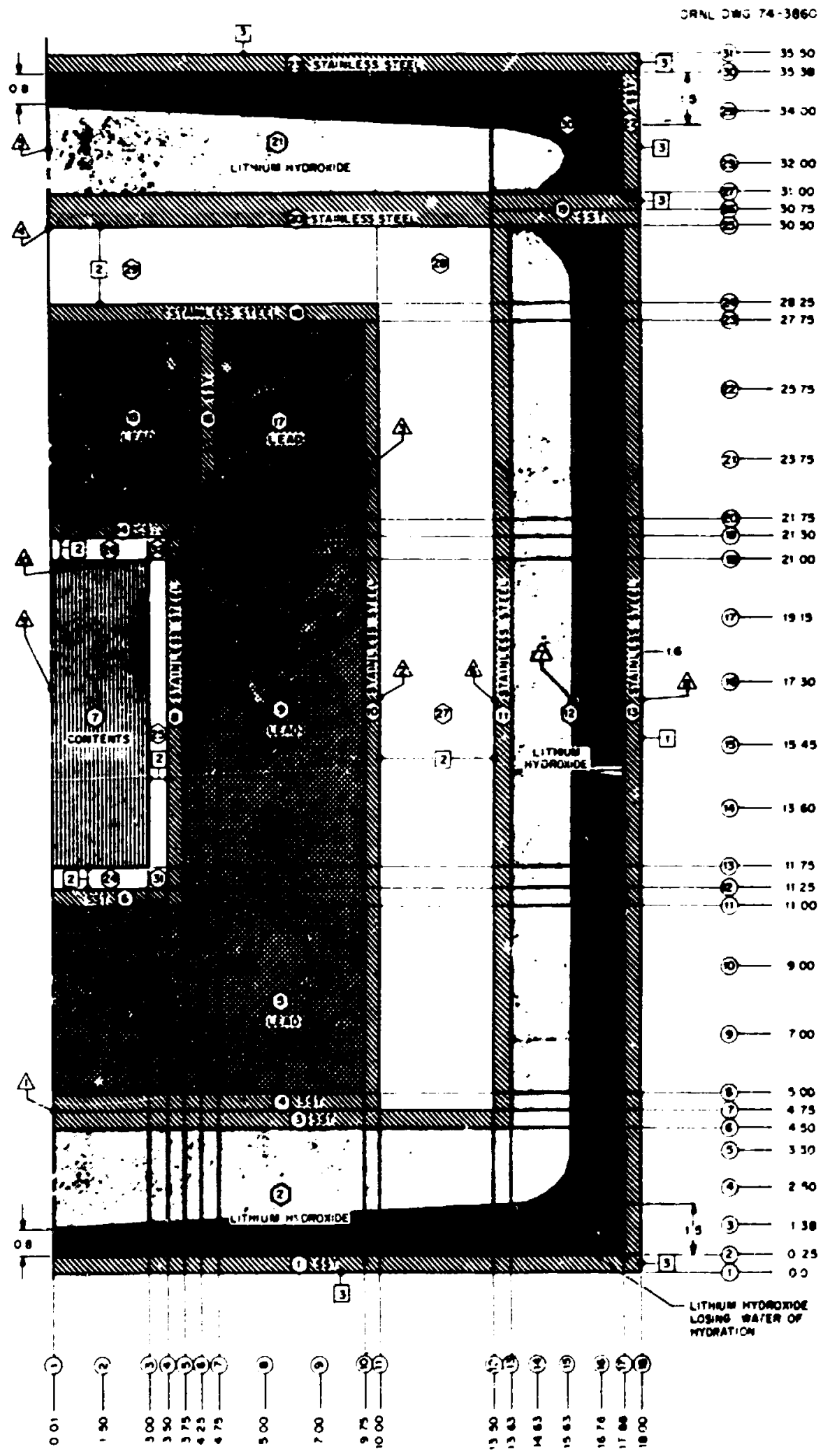

Fig. 2.5. Thermal model - LiOll losing water of hydration. 


\section{CONTAINMENT}

\subsection{Containent Boundaries}

containment boundaries for the shipping options avallable with this pacicage are described below.

\subsubsection{Special form shipments}

For all special form shipments, the welded encapsulation forms primary containment. See Figs. 1.8 and 1.9 for examples of special form encapsulations and Sect. 1.6 for description of ORN special form cert1fication. If the material is doubly encapsulated, the outer welded capsule forms secondary contalnment. These lines of containment are routinely leak checked using mass spectrometer or vacuun-bubble ${ }^{12}$ leak detection technicucy. If required for gama shielding, the inner container forms an additional line of containment. These containers are equipped with gasketed closures but are not generally designed to be leak checked.

\subsubsection{Other shipments}

All materials shipped which do not conform to special fcrm are contained in a Specification $2 R$ container (see Sect. 1.7) which forms primary containment. Typical examples of $O R N L 2 R$ containers are illustrated in Figs. 1.10 and 1.11. These containers are designed to be leak-tight to the extent that water will. not leak from the container at the anticipated pressure and room temperature. The sontainer shown in Fig. l.ii(d) is designed for leak checking and will be leak-tight to the exten = that leaks are not detectable by appropriate techniques. All powders and other dispersibles will be shipped In $2 R$ containers which are leak checked. Solids such as metal specimens, etc., may be shipped in containers which are not designed for leak checking.

If required for gamma shielding, an iuner container forms secondary containment. 


\subsection{Requirements for Normal Conditions of Transport}

The test sequence for special form is more severe than the requirements for normal conditions of transport; hence, there will be no release of radioactive material from the contalnment vessel(s). The pressure rises encountered will be less than those experienced in the special form thermal test. There will be essentially no contaminatiou of primary coolant (air), nor will there be a loss of coolant.

The 2R containers are designed (see Sect. 1.7) for pressures and temperatures in excess of those encountered in normal transport; hence, there should be no release of radioactive materfal, loss of coolant (air), nor contamination of coolant.

\subsection{Requirements for the Hypothetical Accident Conditions}

The test series for special form demonstrates tha: special form encapsulation will not fail nor leak contents as the result of the free falls as long as the shield(s) remains intact. The test and calculations in Sect. 1.5 demonstrate this. The special form thermal test results in temperatures in excess of those applicable to the contents during the specifled thermal exposure (see Sect. 2); hence there will be no release during the thermal exposure. The water immersion test for special form is identical to the hypothetical accident.

Likewise, the design pressure and temperature (see Sect. 1.i) for the $2 R$ containers are not exceeded dur'ag the accident. The silicone rubber gaskets, maximum service temperature of, $00^{\circ} \mathrm{F}$ : 11 not be exceeded. The impact wili not ovcrstrcss the contaiut. Hence, there will be no detectable loss of contents from the $2 R$ container. The tests outlined below were conducted to establish ability of $2 R$ containers to maintain containment after a 30-ft drop impact.

On August 21, 1974, two each of the Specification $2 R$ containers as illustrated in Figs. 3.1 and 3.2 were drop tested at ORNL to establish lite adequacy of this cype of conlainer as bite prithary containment vessei for radioactive materials. This type of container is extensively used at ORNL in confunction with various shielded casks. Normally, the containers are assembled using forged caps for both end closures. 

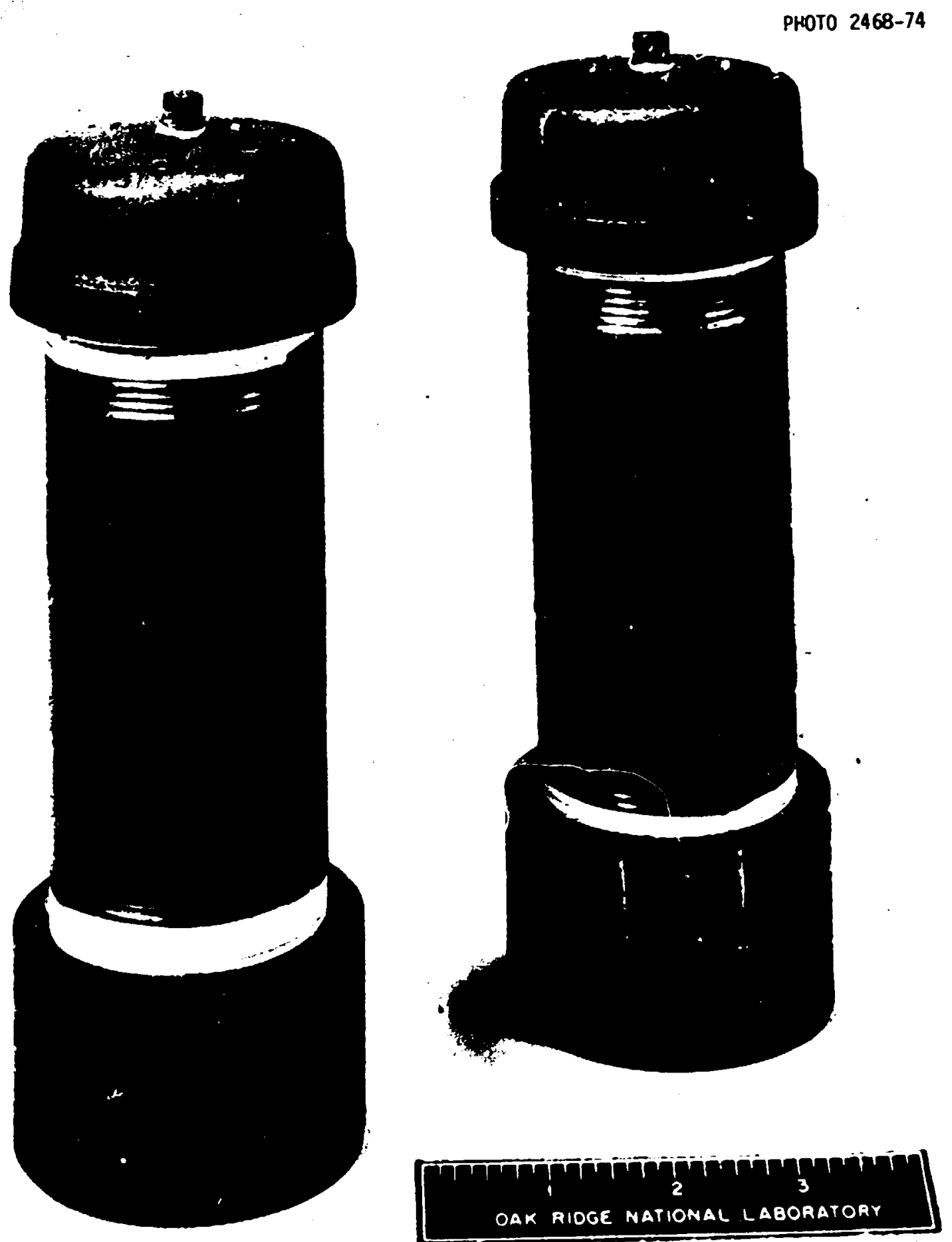

F1g. 3.1. 2R test models. 
ORNL OWG 74-8940

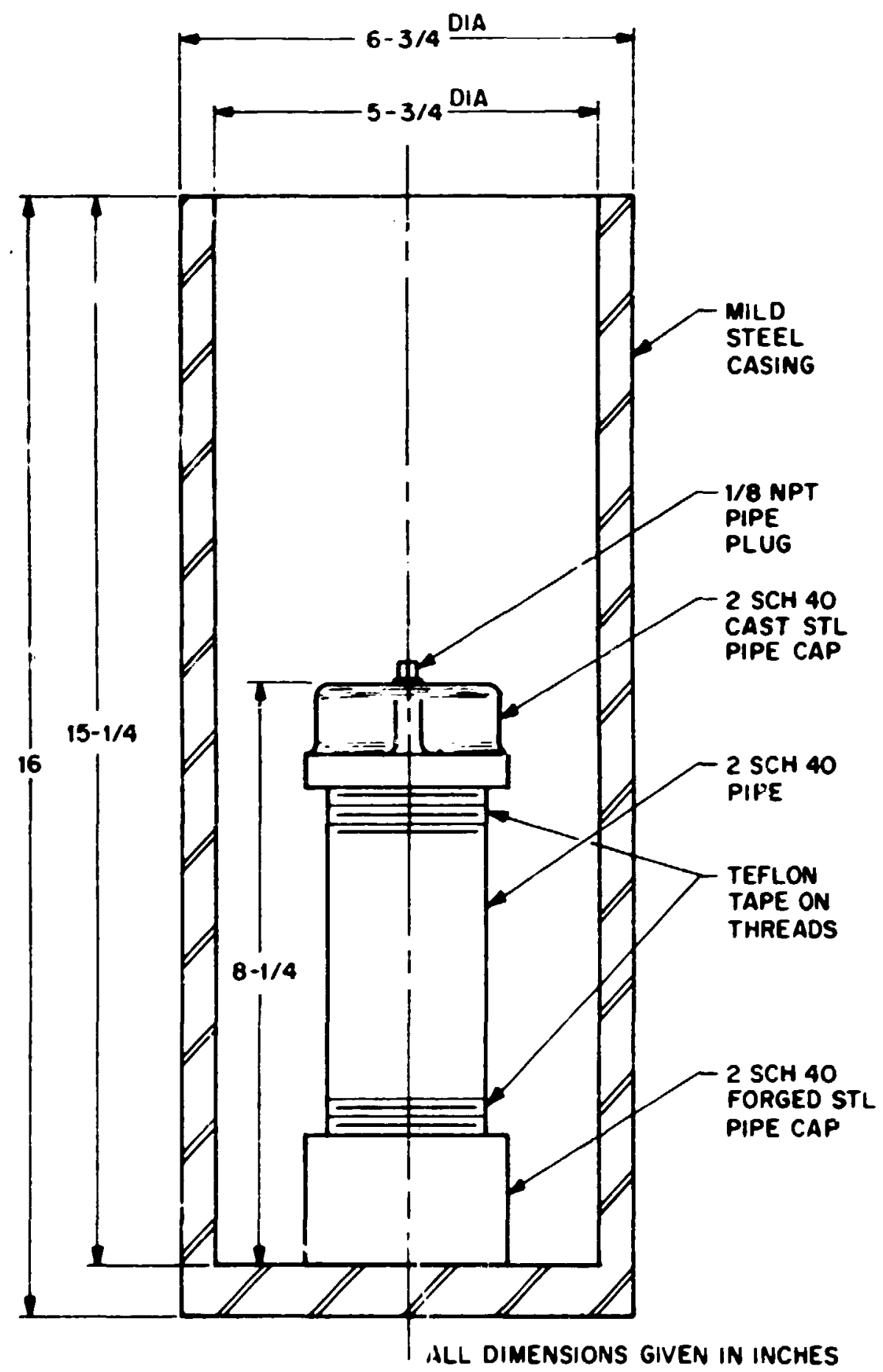

Fig. 3.2. LR test model. 
Frequently, one cap is welded to the plpe nipple, enhancing its structural integrity. Both steel and stainless steel pipe and caps have been used. For this test the cas: steel (malleable) caps were used at one end due to a temporary shortage of forged caps. In all the tests conducted, the forged cap was the point nearest the point of iopact. The cast cap is not considered a part of the test except to facilitate leak testing.

Both containers were air-soap-bubble leak tested at 10 psig prior to testing. There were no detectable leaks. The first container was filled with tap water, placed in an existing steel casing (see Fig. 3.2), and dropped from a height of $30 \mathrm{ft}$ onto the ORNL pad, impacting at an angle of $\sim 17.3^{\circ}$. The angle of impact was calculated from the deformation dimensions of the casing. The casing was used to simulate the protection afforded by the cask. The second container was also filled with tap water, then placed in the casing and dropped as above on its. end. The containers were drained using the pipe plug in the top and soap-bubble tested at $10 \mathrm{psig.} \mathrm{There} \mathrm{were} \mathrm{no} \mathrm{detectable} \mathrm{leaks.}$

Both containers were then refilled with water. The first container was dropped frow a height of $30 \mathrm{ft}$ onto the pad without any outer protection. It Impacted at a very flat, oblique angle. No leakage of water was observei. There were significant leaks at both threaded foints when the containers were air-soap-bubble tested at $10 \mathrm{psig}$. The second contalner was dropped as above suck that the plane containing the point of impact and the center of gravity was essentially vertical. Again, there was no vistble loss of water. A 10-psig air-soap-bubble test revealed significant leakage around the lower (nearest to the point of 1mpact) threaded foint.

It is concluded that a $2 R$ container made of threaded stainless or carbon steel pipe and forged steel or stainless steel caps 1 s adequate to provide pritary containment when inside the L1OH container. It is also concluded that such a container is not adequate without some external protection. It is obvious that the accelerstions experienced by the test contalners in the steel casing were of greater magnitude than would be experienced in a shipping cask. 


\section{SHIELDING}

Shielding from neutrons is effected by the $\mathrm{LiOH} \cdot \mathrm{H}_{2} \mathrm{O}$ in the fire and impact shield. When required, gamma shielding is provided by an inner container meeting DOT requirements. The user is required (see Sect. 6) by the operating procedures and checklist to monitor each packuge to ensure that the external radiation dose rate does not exceed that allowed by the regulations.

The hypothetical accident will not reduce the shfelding effectiveness of an inner container. There will be no significant redistribution of lead shielding, and no lead will melt (see Sects. 1.5 and 2.4). The specified temperature excursion will result in a reduction in the effectiveness of shielding from neurrons. The water of hydration will be evaporated, and the $\mathrm{LiOH} \cdot \mathrm{H}_{2} \mathrm{O}$ will become $\mathrm{LiOH}$ in the region indicated in Fig. 2.5. The effect of this shielding loss was evaluated. A copy of the results of these calculations is presented in Appendix $G$. In summary, this evaluation demonstrates that if the neutron dose rate level is equal to the maximum allowable for shipment, it will not exceed the allowable after the accident.

\section{CRITICALITY}

The regulations require that packages used for the transport of fissile material shall be so designed and constructed, and the contents so limited, that they would be subcritical if it is assumed that water leaks into the containment vessel; that water moderation of the contents occurs to the most reactive credible extent consistent with the chemical and physical. form of the contents; and that the containment vessel is fully reflected on all sides by water.

There are additional requirements for packages containing liquids which do not apply to the $\mathrm{LIOH}$ shield. It is also required that a package used for the shipment of fissile material shall be designed and constructed, and its contents so ifmited, that under normal conditions of transport specified in the regulation, considered individually, the package will be subcritical and the geometric form of the package contents will not be substantially altercd. There will be ro leakage of 
water into the containment vessel. This requirement need not be met if, in the evaluation of undamagea packages for complianc. with Fissile class I requirements below, it has been assumed that moderation is present to such an extent as tc sause maximum reactivity consistent with the chemical and physical form of the material.

It is also required that when subjected to the specified normal conditions of transport, there will be no substantial reduction in the effectiveness of the packaging, including the specific requirements below: (1) a reduction by more than $5 z$ in the cotal effective volume of the packaging of which nuclear safety is assessed; (2) a reduction by rore than 57 to the effective spacing on whi:h nuclear safety is assessed between the center of the containment vessel and the outer surface of the packaging; (3) the occurrence of any aperture in the outer surface of the packaging large enough to permit the entry of a 4-in. cube.

The regulations specify that a package used for the shipment of fissile material shall be so designed and constructed, and its contents so limited, that if subjected to the sequence of the hypothetical accident conditions specified in Annex 2 of the regulations, the package would ie subcritical. In determining whether this standard is satisfied, the conditions outlined below shall be assumed.

The fissile material is in the most reactive credible configuration consistent with the damaged condition of the package and the chemical and physical form of the contents.

Water moderation occurs to the most reactive credible extent consistent with the damaged condition of the package and the chemical and physical form of the contents.

There is reflection by water on all sides and as close as is consistent with the damaged condition of the package.

A Fissile Class I package shall be so designed and constructed, and its contents so limited, that compliance with the requirements below are ensured.

Any number of such undamaged packages would be subcritical in any arrangement, and with optimum interspersed hydrogenous moderation unless there is a greater amount of interspersed moderation in the packaging, 
in which case that greater amount may be considered. Two hundred fifty such packages would be subcritical in any arrangement, if each package were subjected to the sequence of the hypothetical accident conditions specified in Annex 2, with close reflection by water on all sides of the array and with optimum interspersed moderation unless there is a greater amour. of interspersed moderation in packaging, in which case that greater amount may be considered. The condition of the package shal: be assumed to be as described below.

It shall be assumed that the fissile material is in the most reactive credible configuration consistent with the damaged condition of the package, the chemical and physical form of the contents, and controls exercised over the number of packages to be transported together. It sha11 also be assumed that water moderation occurs to the most reactive credible extent consistent with the damaged condition of the package and the chemical and physical form of the contents.

The ORNL Criticality Committee has evaluated the package and its contents as described in Sect. 0.2 and the as-built drawings in Appendix A. This evaluation, presented in Appendix $\mathrm{H}$, demonstrates compliance with the regulations for Fissile Class I shipments.

\section{QUALITY ASSLRANCE}

\subsection{Fabrication, Inspection, and Acceptance Tests}

The majority of the fabrication work on these shields was performed prior to the requirements for a formal quality assurance program. The Eabrication was performed in ORNL Shops in accordance with normal shop fabrication procedures. Material was specified on the original drawings as "304L SST." Material was withdram from ORNL Stores stock. The material used conforms to the requirements of note $I$ of as-built drawing M-11566-EM-001-D, since ORNL Stores stock is purchased by these specifications. The existing weldments were inspected by ORNL Inspection Engineering Department personnel for conformance to the as-built drawings and quality of workmanship required by the drawings. In the opinion of the inspecting personnel, the weldmen's were built in accordance with the drawings and specifications. The Inspection Engineering report is presented in Appendix I. 
The modifications to the weldments were performed in accordance with the drawings, notes, and the ORNL Quality Assurance Procedures applicable to Quality Level III fabrication. The velds were nade in accordance with the WPS procedures and inspected as specified by note II. 2 of the drawings. The material us $2 d$ in modifications was withdrawn from ORNL Stores stock which was purchesed in accordance with the specifications in note $I$. The lithium hydioxide monohydrate was poured in accordance with the procedure on the drawing (note VI). The leak tests required by note III of the drawing were performed to verify the integrity and leak-tightness of the weldment. rimensional inspections of the completed containers were performed. Wald and dimensional inspection reports and leak tests reports are presented in Appendix I. Each container was tested for homogeneity of the $\mathrm{LiOH} \cdot \mathrm{H}_{2} \mathrm{O}$ pour (neutron shielding) per note VI of the drawing.

\subsection{Opsrating Procedures and Routine Inspection}

The ORNL Operations Division has established packing and routine inspection procedures to ensure that all shipments are safe and comply with the regulations. ${ }^{1-3}$ Copies of the procedures and checklists are presented in Appendix C.

\subsection{Perlodic Maintenance and Inspection}

The design of the shield is such that a dye penetration inspection report, no older than six months, must be maintained in the container's QA file. In addition, the gaskets are replaced every six months. Additional maintenance will be required only when routine inspections indicate damage. There are no time-degradable materials used in the construction of the shields. All inspection and maintenance reports are to be included in the QA files. These files must be auditable and maintained for the ilfe of the container. 


\section{REFERENCES}

1. United States Atomic Energy Cormission, "Safety Standards for the Packaging of Radioactive or Fissile Haterials," in AEC Marual, Volume 0000, General Administration, Part 0500, Health and Safety, Chapter 0529, June 14, 1973.

2. Code of Eederal Reguzations, Title 10, Part 71, "Transport of Licensed Materials."

3. Code of Federal Reguiations, Title 49, Parts 172 and 173, "Transportation."

4. Code of Fedenal Regulations, Title 49, Part 178, "Transportation."

5. ASRE Boiler ari 'ressure Vessel Code, Section VIII, "Pressure Vessels," Division I, American Society of Mechanical Engineers, New York, July 1, 1974.

6. Joseph H. Faupel, Engineering Design, a Synthesis of Stress Analysis and Materials Engineering, Wiley, New York, 1964.

7. W. D. Turner and M. Siman-Tov, HEATING-3, an IBM 360 Heat Conduction Program, ORNL/TM-3208 (February 1972).

8. E. Oberg and F. 0. Jones, Machinery's Handoook, Industrial Press, 17th Ed. (1964).

9. F. C. Davis, Structural Analysis of Shipping Casks, Vol. 9, Energy Absopition Capabilities of PIastically Deformed Struts under Specified Impact Loading Conditions, ORNL/TM-1312 (February 1971).

10. D. S. Clark, The influence of Impact Velocity on the Tensile Characteristics of Some fircraft Metals and Alloys, National Advisory Committee for Aeronautics, Technical Note No. 868 (October 1942).

11. J. H. Evans, Design uri Aralysis of the Wew Brurswick Laboratory High Level waste Cask, ORNL/TM-4242 (June 197.3).

12. R. G. Niemeyer, Leak Jesting Encapsulated Radioactive Sources, ORNL-4529 (July 1972).

13. F. Kreith, Principles of Heat Transfer, International Textbook Company, Scranton, Pa., 1966.

14. J. H. Evans, Safety Analysis Report for Fackaging Lawrence Livermore Laboratories Shipping Contairers, ORNL/TM-4905 (in publication).

15. R. D. Seagren, personal comunication (unpublizhed data).

16. L. B. Shappert, Cask Designer's Guide, ORNL/NSIC-68 (February 1970). 
Appendix A

AS-BUILT DRAWINGS 


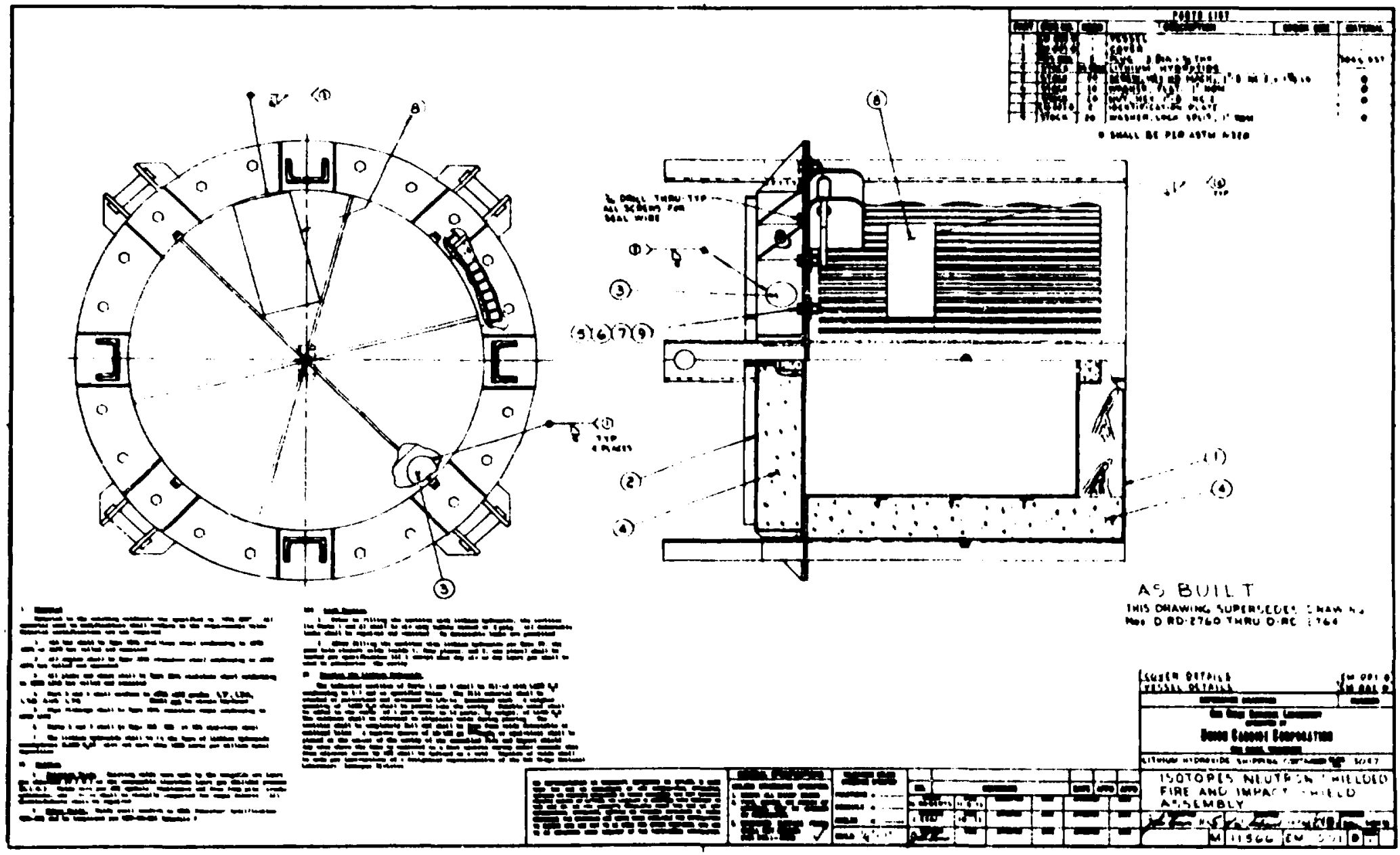

Fig. A.1. As-built drawing no. M-11566-EM-001-D. 


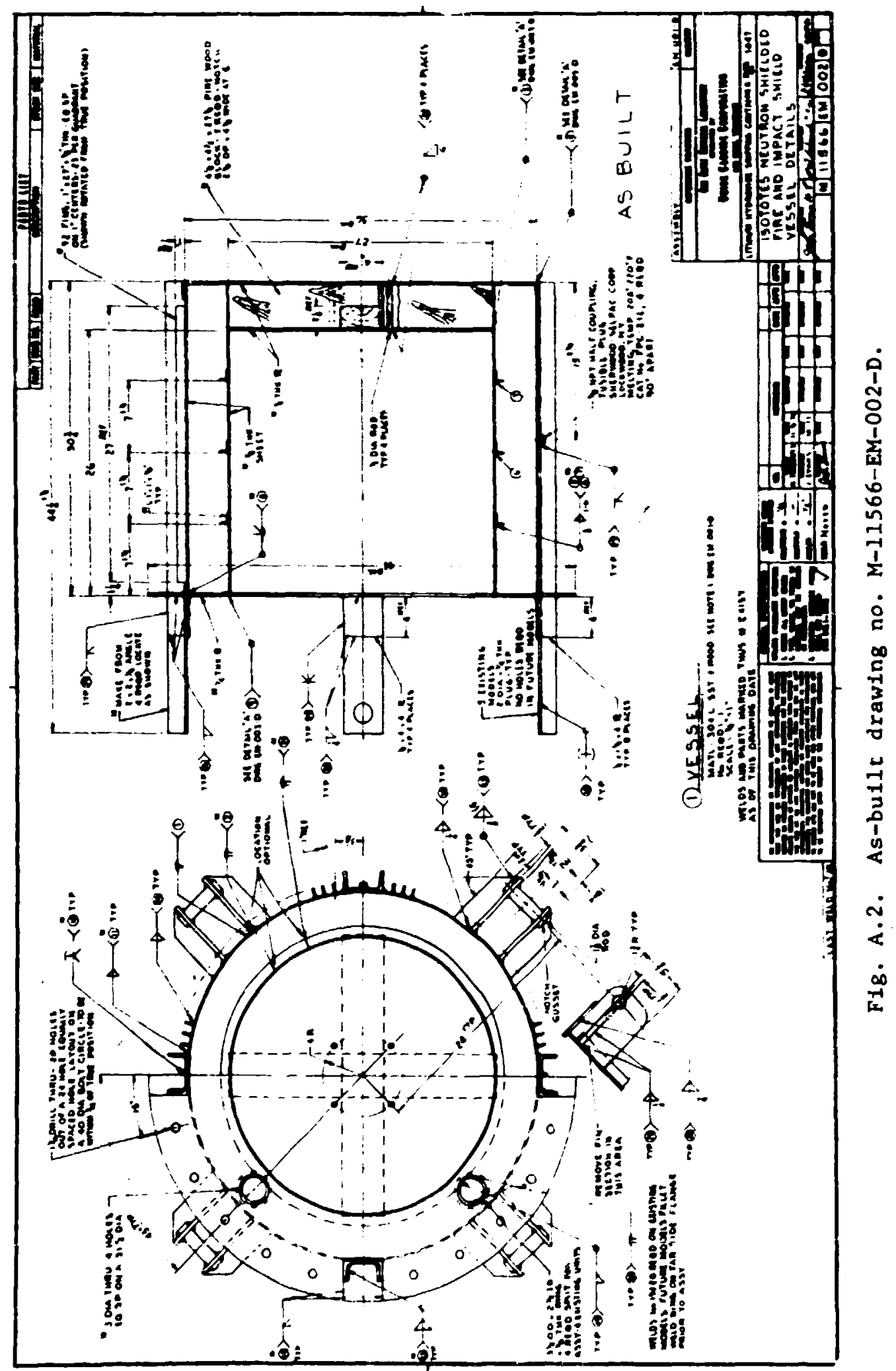




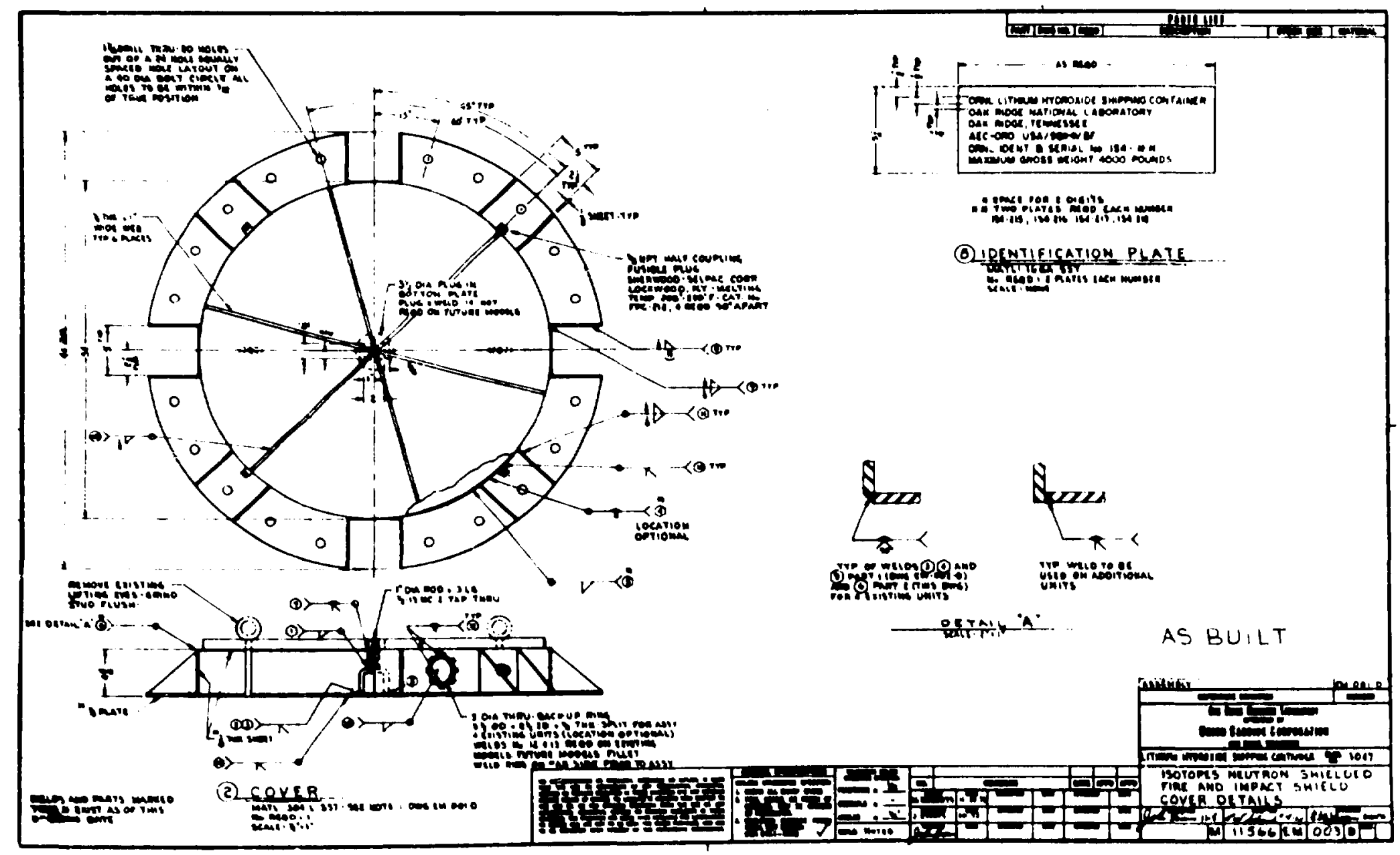

Fig. A.3. As-bullt drawing no. M-11566-EM-003-D. 
Append Ix B

APPROVAL DOCUMENTS 


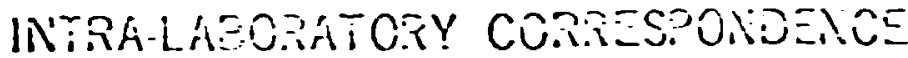

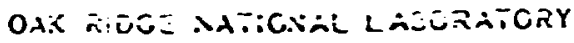

Decerjoz= 16,1974

TC $74-3$

To: J. H. Evars, R. W. Scisich

From: Transportazion Comizice

Sibject: dpproval of SARP fo: the 0.NL Lithiun Hydroxide Fire and Inpact Shield

Tis ORlz Transportation Commitzee has revicwed your subnissica of tie

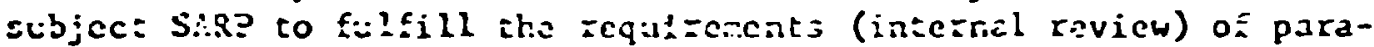
graph $y$ of ACC Insaciaze Action Di rectiva 5201-3. Particular aztention was given the five azeas of structural iategrity, thermal resistancé, radiation shiclding, nuciear criticality safety, ard quality sisurance.

The results of the evaluation show that tie shield neets the requitements of AECY OS29 and the SAR? is approved for suimission to the AEC for request of a Certificate co Complianca for approval of the shiela

- for use as described for offsice shiprents of fissile and radioactive raterials.

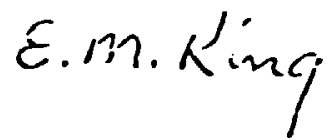

E. M. King, Chaiman

Transfortation Conmitcea

Ex:د'

cc: Trassportation Comittec 


\begin{tabular}{|c|c|}
\hline 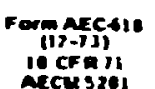 & 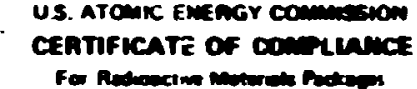 \\
\hline
\end{tabular}

\begin{tabular}{|c|c|c|c|c|c|}
\hline $\begin{array}{l}\text { iv. Certives Mand } \\
\text { USA/9852/BLF }\end{array}$ & $(\mathrm{BRDA}-0 \mathrm{RO})$ & $\begin{array}{l}\text { 10. Ammion No. } \\
0\end{array}$ & 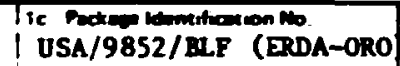 & 1d. nemp. & 10. Totol No. Hes \\
\hline
\end{tabular}

2. MAEANBLE

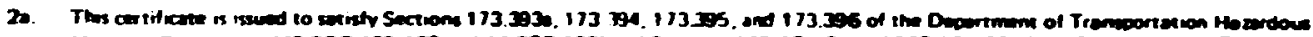

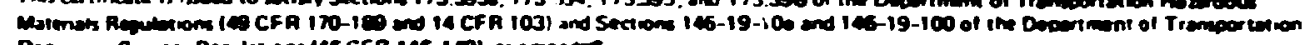

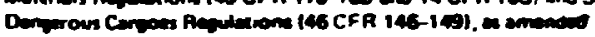

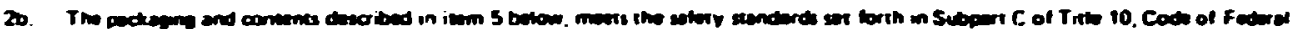

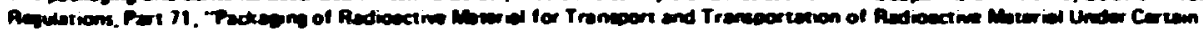
Condion.:

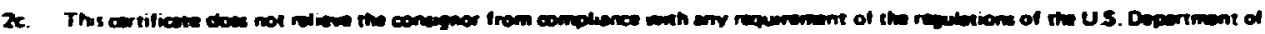

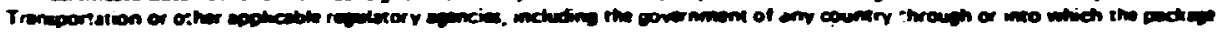
mill be tramportad.

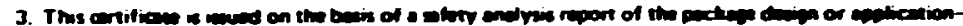

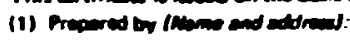

Oak R1dge National Laboratory

Post office Box $Y$

Oak Ridge, IN 37830

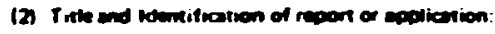

13. One

Safety Analysis Report for

November 1977

Packaging for the ORuL Lithium Hydroxide Fire and Impact Shield

Report No.: ORNL/ENG/TM-8

4. CONOITICNS

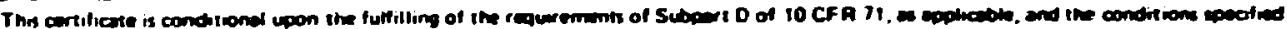
in ivem 5 bellow.

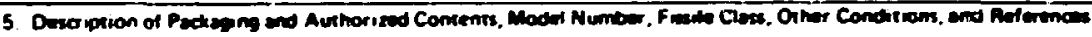

(a) Packaging:

(1) Mode1: Itchium Hydroxide Pire and Inpact Shield

(2) Description:

Packaging for Inner Type A and DOT Specification 55 packages to permit transport of Type $B$ and large quantitles of radioactive materials and linted quantities of fissile materials, which are contained within Inner special form encapsulation or DOr Specification $2 R$ containers. The inner vessels will be blocked to minimize movement during transport.

The inner cavity of the shield 13 a cyllncer $27 \mathrm{in}$. diameter $\times 26 \mathrm{in}$. high. The outer shell $1836 \mathrm{in}$. diameter $\times 303 / 4 \mathrm{in}$. high.

The 11d is $45 / 8$ in. thick. The shield 18 fabricated from $1 / 8 \mathrm{ln}$. thick 304-L stainless steel with the $41 / 4 \mathrm{in}$. nominal space between inner and outer cladding belng fllled with $\mathrm{L} 10 \mathrm{H} . \mathrm{H}_{2} \mathrm{O}$ crystals. The outer surface of the shleld has 92 vertical cooling fins. The flanged closure ts held In position by twenty one-inch alloy steel bolts.

The gross welght of the package 18 4,000 1bs.

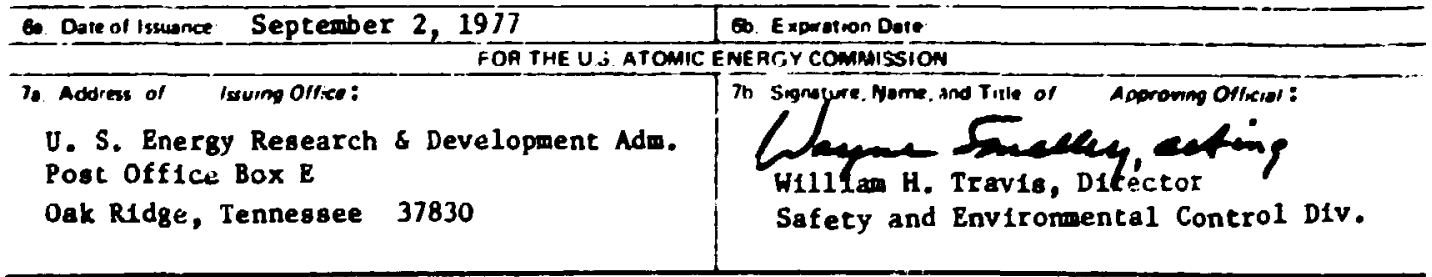


Page 2 - Certificate of Compliance, No. USA/5595/BL (ERDA-ORO), Rev. 0

(3) Draulngs:

The overpack is described and fabricated in accordance with Union Carbide Corporation, Nuclear Division, Oak Ridge National Laboratory drarings :

$$
\text { D-RD-2760-D through D-RD-276;-D }
$$

(b) Contents:

(1) Type and form of aterial:

Any solid, large quantity of radioactive materials, fissile and nonfissile, neting special fore or packaged in DOT Specification IR Inner contalner and whose decay heat load does not exceed 300 watts.

(2) External radiation levels will be within the levels prescribed in Dor Regulations, Title 49.

(3) Specific linits of contents:

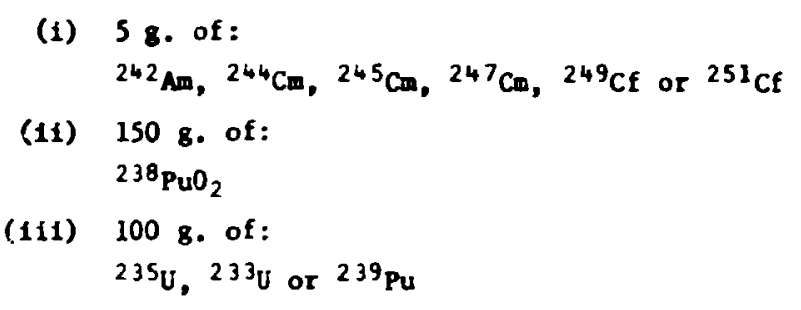

(c) Figsile class: 
Appendix C

ROUTINE PACKAGIKG AND INSPECTION PROCEDURES 
OPEKATIO:S MVISIJU

RAI LOISOTOHE DEPARTFE.IT

OAK RIDGE NATIOIAL LABORATORY

RADIOISOTOPE PACKAGING AHD SHIPPING PROCEDURE

rruc. $\because 2 \frac{1}{\text { of } 3}$
Page $\frac{1}{2717 / 77}$
Date

OPERATIOAS DIVISION

PROCEDURE FOR APPROVAL TO SHIP RADIOACTIVE HATERIAL

1. All requests to ship radioactive material are first referred to the SS Materials Managenent Department or to the Isotopes Sales Office for approval (reference: Isotopes Sales Operating Homal ard the huclear Hateriais Hanagenent fonual, ORL-2800 (Revised)].

2. Radioactive Katerials Packaging Form (UCA-12301) is completed by the requester and attached to the Special Horks data sheet (UCH1784) or the SS Accountability docuent (UCA-2681). The supervisor of the Dadiolsotope Packing and Shipping operation reviews the informtion provided and flags all shipping docunents for shipments requiring Type "B" shipping containers.

3. Docurentation of requests for shipping radioactive materials with half-lives $>14$ days 18 subdiced cwo full working days before the scheduled shipping date to give adequate tine for review of package docunentation and approval of the shipnent.

4. Documentation of requests for shipment of radiosctive anterial inth a half-11fe of <14 days must be submitted by 1:00 PH on the day before the scheduled shipping date.

5. The review of packaging documentation follows the procedure established in ORNL-T7-2769, ORHL Isotopes Division Guide for the Packaging of Radioactive Materials for Tronsport, and Muclear Materials Management Mmual, ORL-2800 (Revised).

6. A Radioactive Materials Packaging Form (UCN-12301) is required for all returnable concainer shipents (eopty or full) and for all thipents containing $>1$ wCi alpha or $>3 \mathrm{Ci}$ beta-gavma.

PACKING AND SHIPPING PROCEDURE

1. The supervisor of the Radioisotope Packing and Shipping Operation (RPSO) receives approved shipping documenrs (UCN-2775) from the SS Materials Mnagement and Isotopes Sales Group by 1:00 PM on thr. day before the shipment is scheduled to leave ORNL.

2. The RPSO supervisor reviews each shipping docunent and the Radioactive Materials Packaging Form and reports any discrepancies to the Process Group Leader for action. In the absence of the Group Leader, diacrepancier. in the documentation are reported to the Radiofotope Deparraent Superintendent for action.

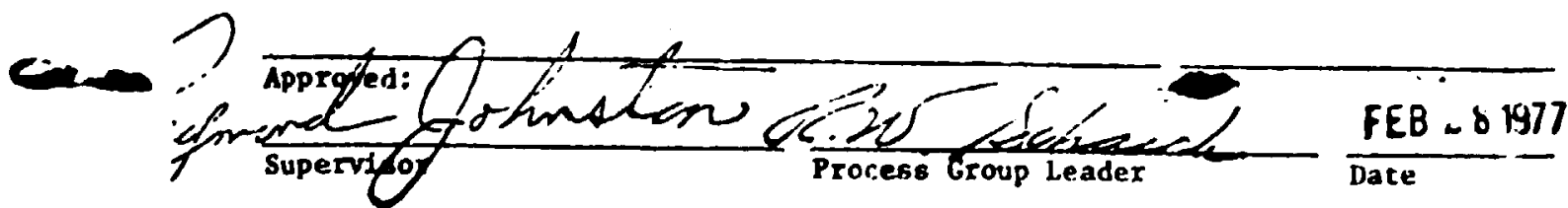


OPEKITIOIS DIVISIU:A
RADIOISOTOPE DEYARTTEIT

l'ruc. : $0-\frac{1}{-c f} 3$
Page $\frac{2}{2 n 17 / 77}-$
Date

3. Nll shipping docuents flaggel as Type " $B$ " are separated by the RPSO supervisor and handled on a personal basis until the unit is properly loaded on the transpirting vehicle. He then signs the Radioactive Materlals Packaging Sorm (UCN-12301) and inediately returas all conpleted documents to the Process Group Leader for a final reviar.

4. In the absence of the RPSO supervisor, the rellef supervisor brings aj.l shipping documents to the Process Group Leader for review and identification of shipments that require special atcention of the rellef supervisor.

\section{EEHERAL PEgULATIONS}

1. Short half-1ife materials ( 14 days) are shipped on Tuesday and Friday of each veek. Special schedules can be arranged for hollday reeks. Hedical isolopes are shipped when required.

2. Long half-life materials (>14 days) are shipped on Wednesday and Thursday of each week. Shipments weighing greater than 300 lbs are shipped on Friday unless spectal arrangements are made.

3. All packages received at Bullding 3038 Packing and Shipping Room wust weet ORML Health Physics Manual Chapter 4.2 requirewents concerning internal transfers of radioactive waterials and oust meet DOT shipping regulations for external radiation ( $<200 \mathrm{mrem} / \mathrm{hr}$ at the surface and $10 \mathrm{mrem} / \mathrm{hr}$ at 3 feet). The RPSO supervisor must be notified by the oribinator of the shipent when he delivers his package to Building 3038.

4. Por each package, botcle of product, source, target, or other for of radioactive material taken to Radioisotope Packing and Shipping, a copy of the Special Work Order or a note must be atcached to the containe: with the folluring information:

A. Quantity of radioactivity actually being shipped.'

B. Chemical form.

c. Concentration of radionuclide in solution, mci/ml.

D. Volume or product weight.

b. Speciftc activity" (1 ist as "C.F." for carrier free where applicable).

f. Assay date and time, 1

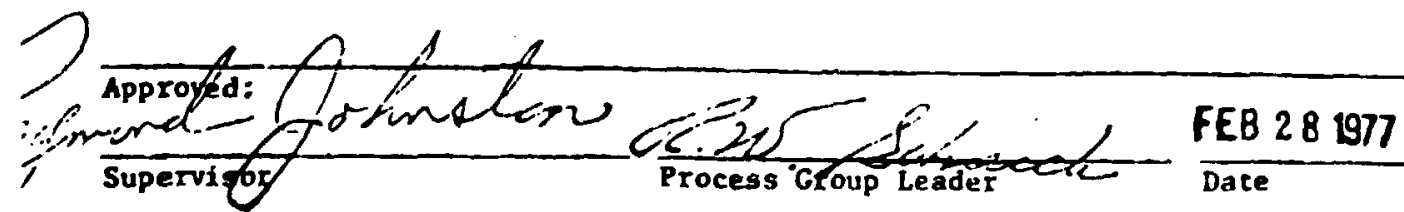


DEFLATERS DIVISIOU

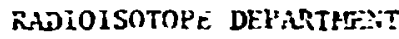

"roc ros $\frac{1}{3}$ of 3
l'ase $\frac{3}{2 / 17 / 77}$
Dare

G. Normality of solu*ions of acids and bases.

H. Radiochemical purity.2

\footnotetext{
IUnprocessed reactor and cyclotron targets are not assayed; therefore, quantity of radioactivity is calculated in these cases. Cyclotron target strip solutions should be enalyzed for quantity of product radioisotope prior to shipwent.

${ }^{2}$ In the case of short-lived radioisotopes, radiochenical furity assay results may be fumished after the shipment is made.
}

In the case of partial shipments of products listed on the Special Work Order a copy of the Special Work Order must be fumished with each partial shipment, and the items on the Special Work Order not being sfilpped wust be marked out.

An Isotope Product Card (attached Form UC1-6216) must be filled out for every radioisotope product solution. In the case of product solutions loaded in shipping containers outside of Radiolsotope Packing and Shipping, a coupleted copy of this form must be subntted with the product container to the Packing Supervisor with a copy $t=$ the Isotofes Sales of $f_{2} c e$.

5. The packaging and shipment of radioisotopes shall follow the Procedures for packaging and Shipment of Padioactive Materials Building 3038 and ORNL-T14-2769, ORNL Isotopes Division Gride for the Packaging of Radioactive Materials for Transport.

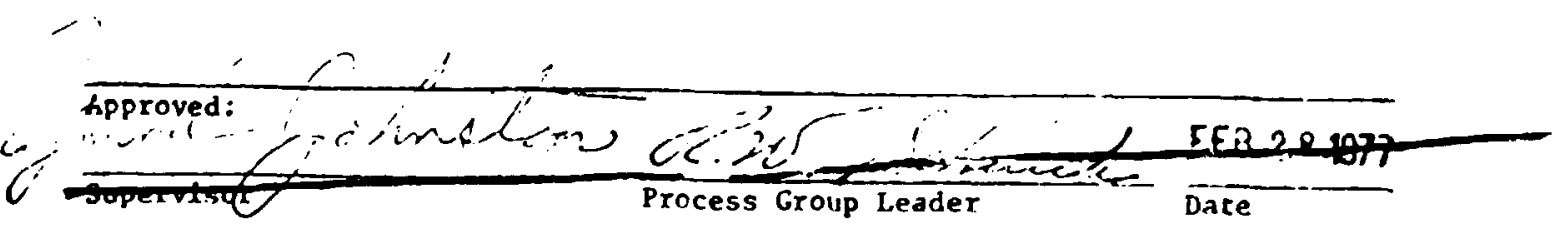


OAK RIOGE MATIONAL LABORATORY RADIOACTIVE MATERIALS PACKAgIMG IWFORMATION

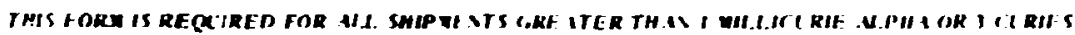

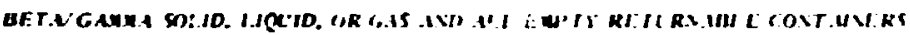

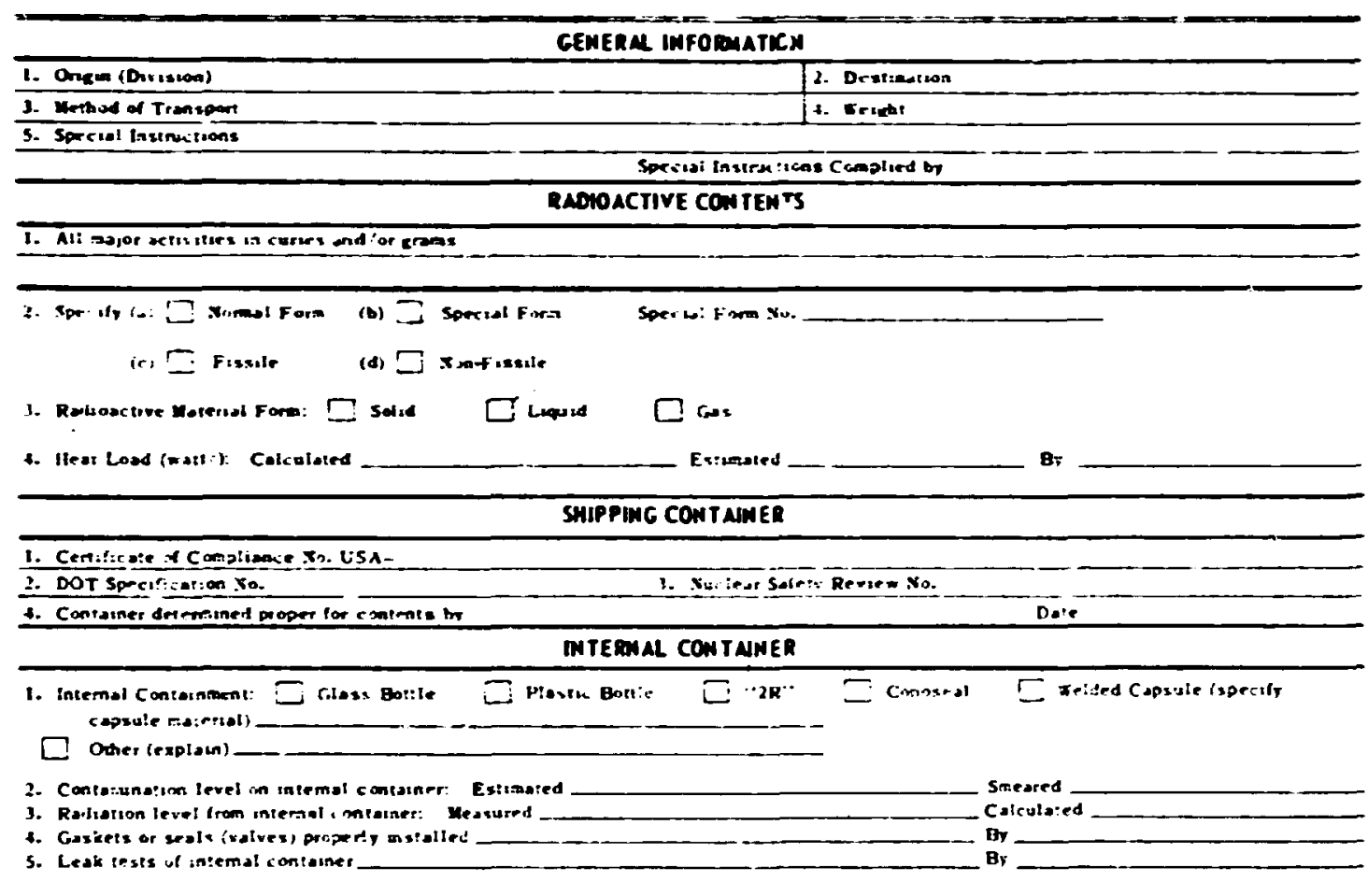

\section{EXTERHAL CONTANER}

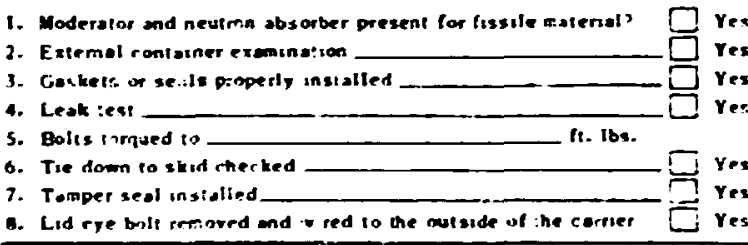

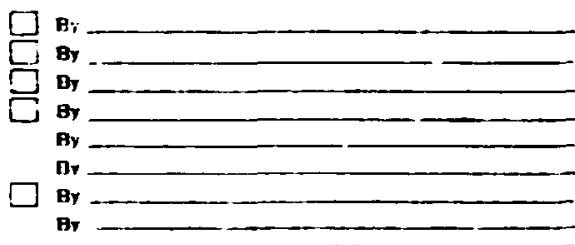

RADIATION SURVEY

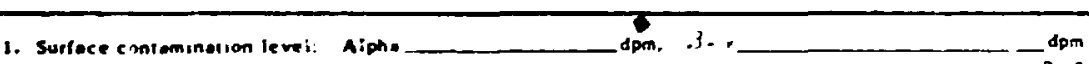

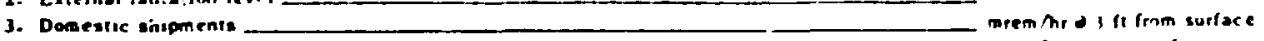

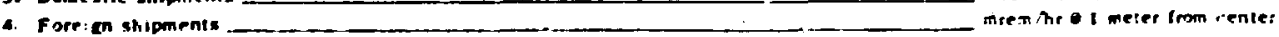

5. Healus Phyenss Surveyne

TRUCK TE.DOWN ANO SHORINC

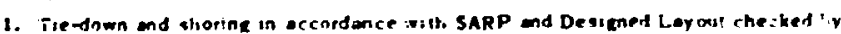

(Insperion Emeuneoring)

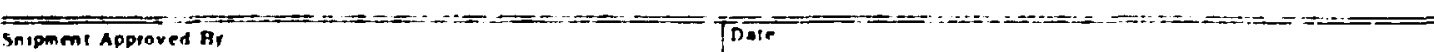

$\longrightarrow$

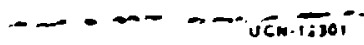

(1) 11.261 


\section{OPERATIONS DIVISION RADIOISOTOPE DEPARTMENT \\ BUILDLNE: 3029 \\ SMIRLE DFVELORMENT LIWGKATOKY \\ QL:ULITY ASSURANCE PROCFDLRE \\ FOR TYPE I SHIPP LNG CONTA INERS}

nane $=\frac{26}{1}$
cane $=-8 / 1777-\ldots$

\section{Inconing Type B Containers}

1. Containet is opened under the supervision of tire Packing foreman and a representative of the Healch Paysics Division. Radiacion readings and swear levels on the external and internal surfaces are recorded. These records are storer it. the audicable Quality Assurance (QA) files in Buildings 3029 anc $30: 7$ by container number.

2. . If container is contaninated externally or internally, it is cleaned to ORin smear tolerances of $500 \mathrm{dis} / \mathrm{min}$ beta-gama or $30 \mathrm{dis} / \mathrm{min}$ alpha. The final smear level is recorded by Health Physics and piaced in the container's QA files.

3. If the radiation level intemally or externally is greater than $1 \mathrm{mr} / \mathrm{hr}$ beta-gama or 500 dis/min alpha, the contairier is to be decontaminated to the above colerance. If decontamination efforts fall, the container is tagged out of service and the Department Head is notified in writing of the status. A copy of the notification is placed in the container's QA files. EXCEPTION: Uranium carriers may rea.t up to $10 \mathrm{mrea} / \mathrm{hr}$ internally or externally.

\section{Fire Stuields}

lue isjou toreman will visually inspect all fire shields for cracks in the wood, protective cratings, foam glass, and/or steel covers. Defects in these Items are to be recorded in the container's QA files and a blanket work order issued imediately to repair same. A copy of the blanket work order and the copy of the completed work order are to be placed in the container's QA flles. An inspection of the repair work is to be made by the RSPO Foreman and a record of acceptance placed in the concainer's QA files.

\section{Gutgoing Type B Containers}

\section{Shielded Containers}

a. Vacuum leak cest will be performed by operating personnel and recorded in the container's QA files in Buildings 3029 and 3037 beforc the contaliner can be used for londing encapsulated radioactive material.

b. An Inspection Engineering report on the intemal weld dye penetrant inspection is valid for 6 months prinr to shipment. If inspection is over 6 months old, a new $\dot{b}$ e penetrant inspection of the internal welds must be made and the resu:'s recorded in the QA files. All repairs will be inspected and appre.ed by Inspectlon Engineering and recorded in the QA files.

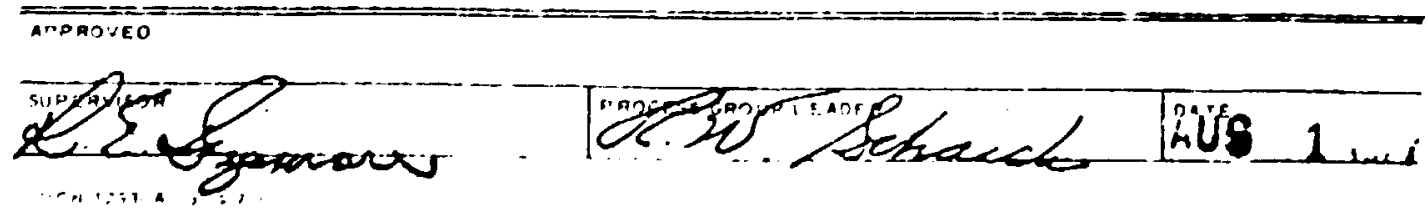




\section{OPERATIONS DIVISION RADIOISOTOPE DEPARTMENT}

c. Gaikets will be changed every 6 months and recorded in the container's QA filus. Gasket macerial from stores stu-l' musi be verified iy the store stock nuber.

\section{Fire Shields}

Fire shield lids and bolting devices will be inspected before shipnent by the Packing Forenan to insure proper fit of the locking wechanisa to hold the lid securely in place during transit. A record of this inspection is to be placed in the container's QA files. All repairs are to be made before shipoent and the blanket work order with its completed fore is to be filed in the container's QA files.

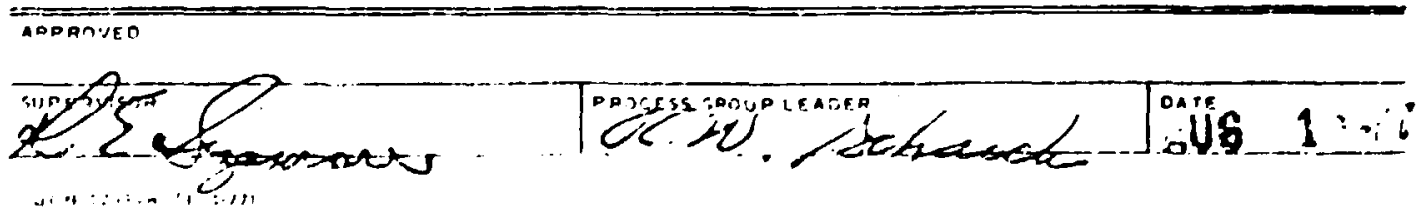




\section{OPERATIONS DIVISION RADIOISOTOPE DEPARTMENT \\ - mo: $00 \frac{26}{3} \frac{5}{5 / 1 / 77}$} BUILDUKC 3029 SOURCE DEVELOPIENT LABORATORY

LKANIUM CASK PACKING PROCEDURE

Pre-Luading Check

1. Chokers for cask handling and lid rewoval checked for proper loading value and certification by Inspection Engineering

2. Vacuun leak test

3. Inspection Engineering report dace (If over 6 wonths since last report, re-inspect)

4. Planned radioactive heat load

a. Neoprene gasket for $<1400 \mathrm{~W}$ installed

b. Silicone rubber gasket for $>1400 \mathrm{~W}$ installed

5. Cavity and lid smear level

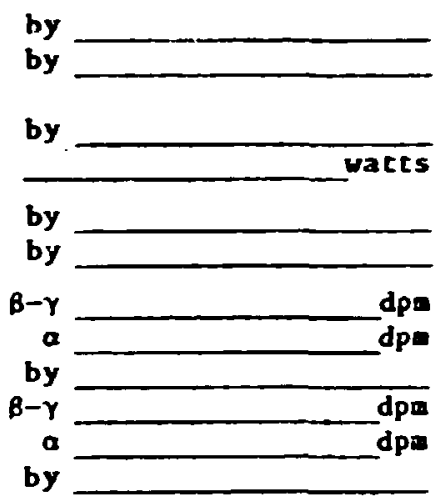

7. Lid closure cap screws, lockwashers, and nuts (16 required), checked for burrs and proper operation by

8. Skid studs and nuts checked for burrs and proper altgnoent by

\section{Post Loading Checks}

1. Ourside cask surface smear level (clean to ORNL smear tolerance for shipping

$B \rightarrow \gamma$

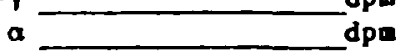

2. Lid closure cap screws free of burrs or damage from in-cell loading

3. LId cap screws torqued to $150 \mathrm{ft},-1 \mathrm{~b}$

4. Tamper seai installed

5. Inaded onto sikid

6. Skid nut torqued to 300 ft.-16

7. Personnel heat shield installed

8. Packaging Information Form (UCN-12301) completed

9. Notification to Packing and Shipping Foreman

by

dpa

by

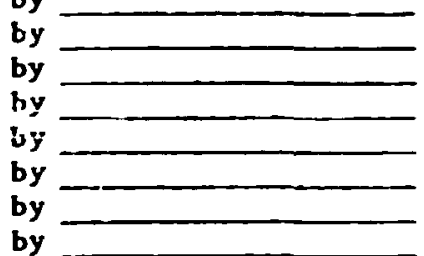

Supervisor Approval by

Date.

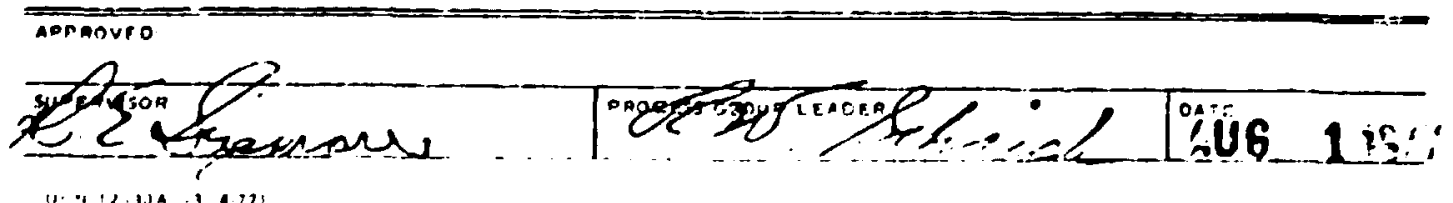




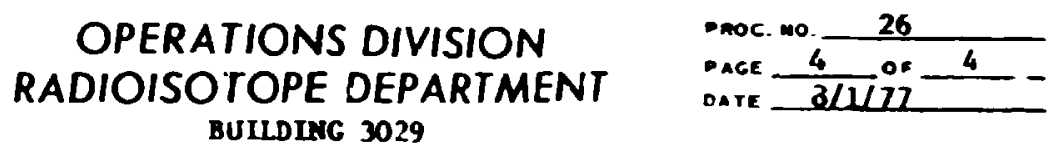

SOURCE DEVELOREAIT LABORATORY

CONTAINER TISPECTIOY SHEET

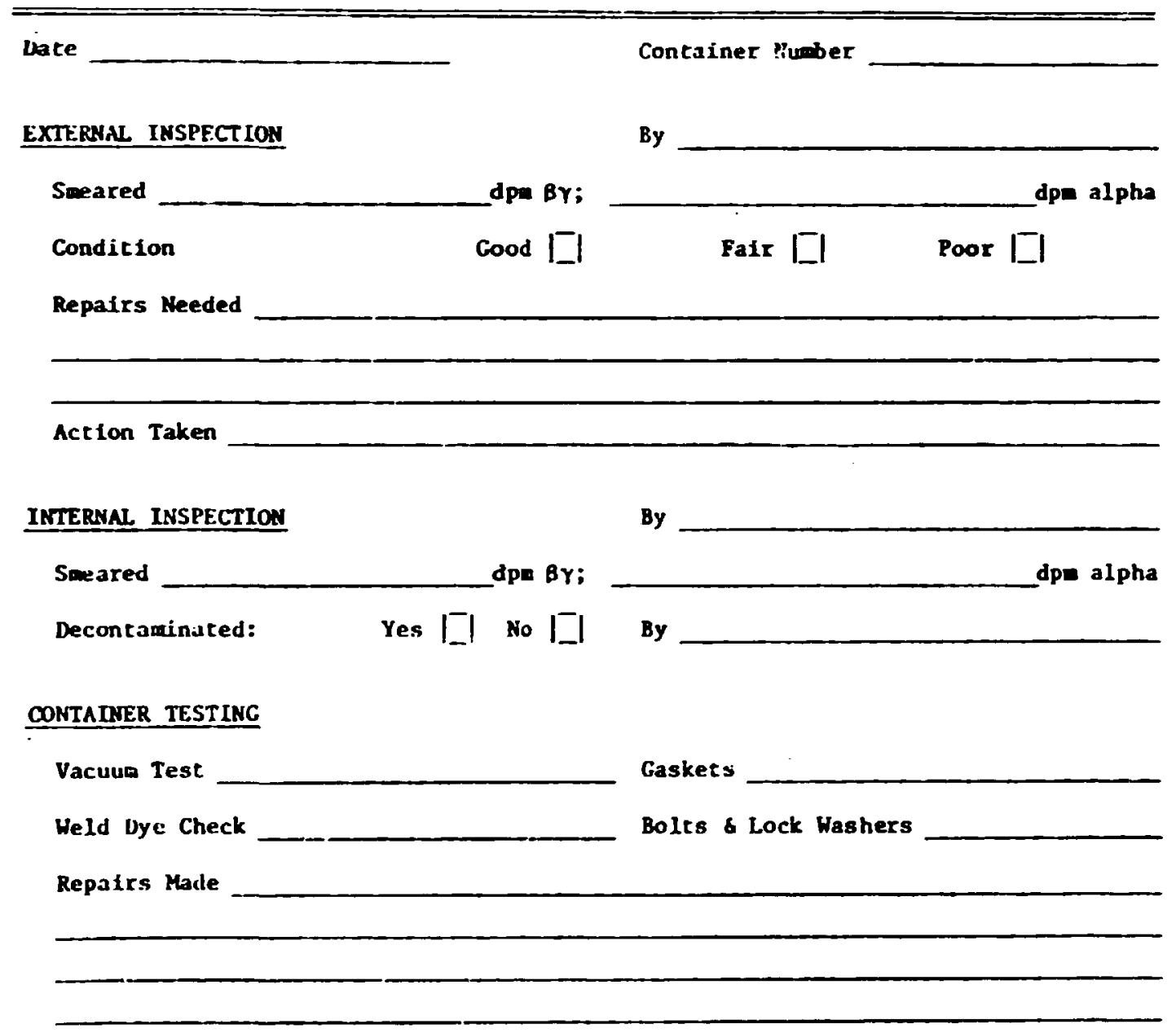

\section{RE-TESTINC}

Vacuum Test

Weld Dye Check

CONTAINER CERTIFIED FOR SHIPMENT - Date

By

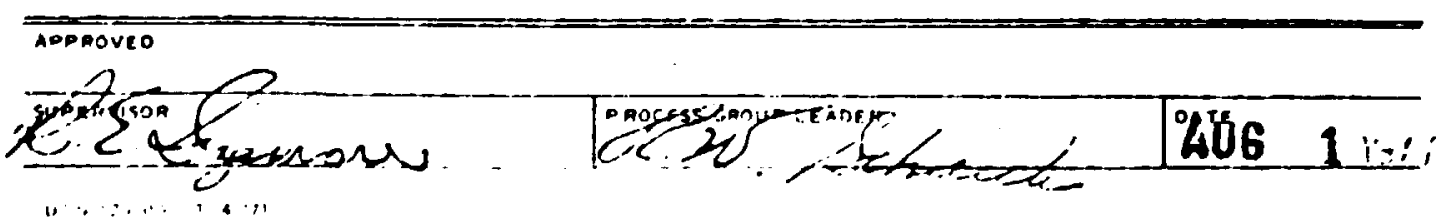


Appendix D

HYDROSTATIC PRESSURE TEST AND COMPUTER

LISTING FOR COMPOSITE HEADS 
Fig. D.1 illustrates the model on which the calculations are based. Two circular plates built in at the edges are connected at their geometric center, forming a sealed cavity. The cinnection, at $b$, is assumed to be rigid; hence there is no deflection at the center of either plate. The plates are loaded by a pressure differential as shown. Note that the analysis is valid if the pressure differential is reversed and the higher pressure is within the cavity. Since at b the deflection $\Delta$ must equal 0 , then by superposition,

$$
\Delta p=\Delta f
$$

where

$$
\begin{aligned}
& \Delta p=\text { deflection due to pressure } P, \\
& \Delta f=\text { deflection due to force } F .
\end{aligned}
$$

Using Roark's notation' (from Formulas for Stress and Stiain, Table $\mathrm{X}$, Cases $b$ and 7 ), and since $r_{0}$ is very small compared with a and the term $r_{0}{ }^{2 / a^{2}}$ can be ignored, we may write

$$
\left[(3 W)\left(m^{2}-1\right)\left(a^{2}\right)\right] /\left(16 \pi E^{2} t^{3}\right)=\left[(3 F)\left(m^{2}-1\right)\left(a^{2}\right)\right] /\left(4 \pi E m^{2} t^{3}\right),
$$

where

$$
\begin{aligned}
& t=\text { thickness of plate, } \\
& W=\pi a^{2} P, \\
& F=W / 4=\pi a^{2} P / 4, \\
& m=\text { reciprocal of Foisson's ratio, } \\
& E=\text { modulus of elasticity. }
\end{aligned}
$$

The radial stress, $\sigma_{r}$, at any radius, $r$, is

$$
\sigma_{r}=\sigma_{r P}-\sigma_{r F}
$$



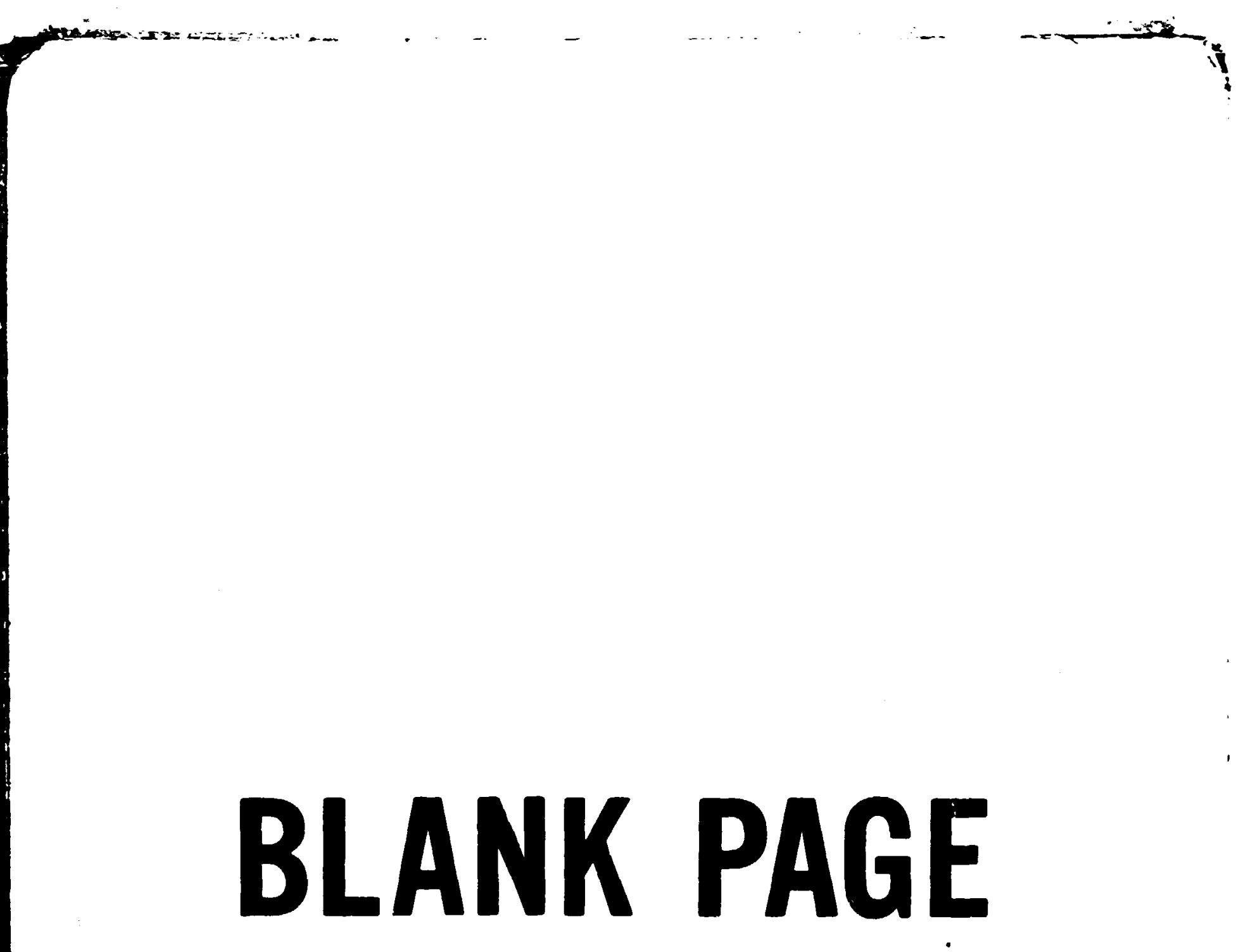


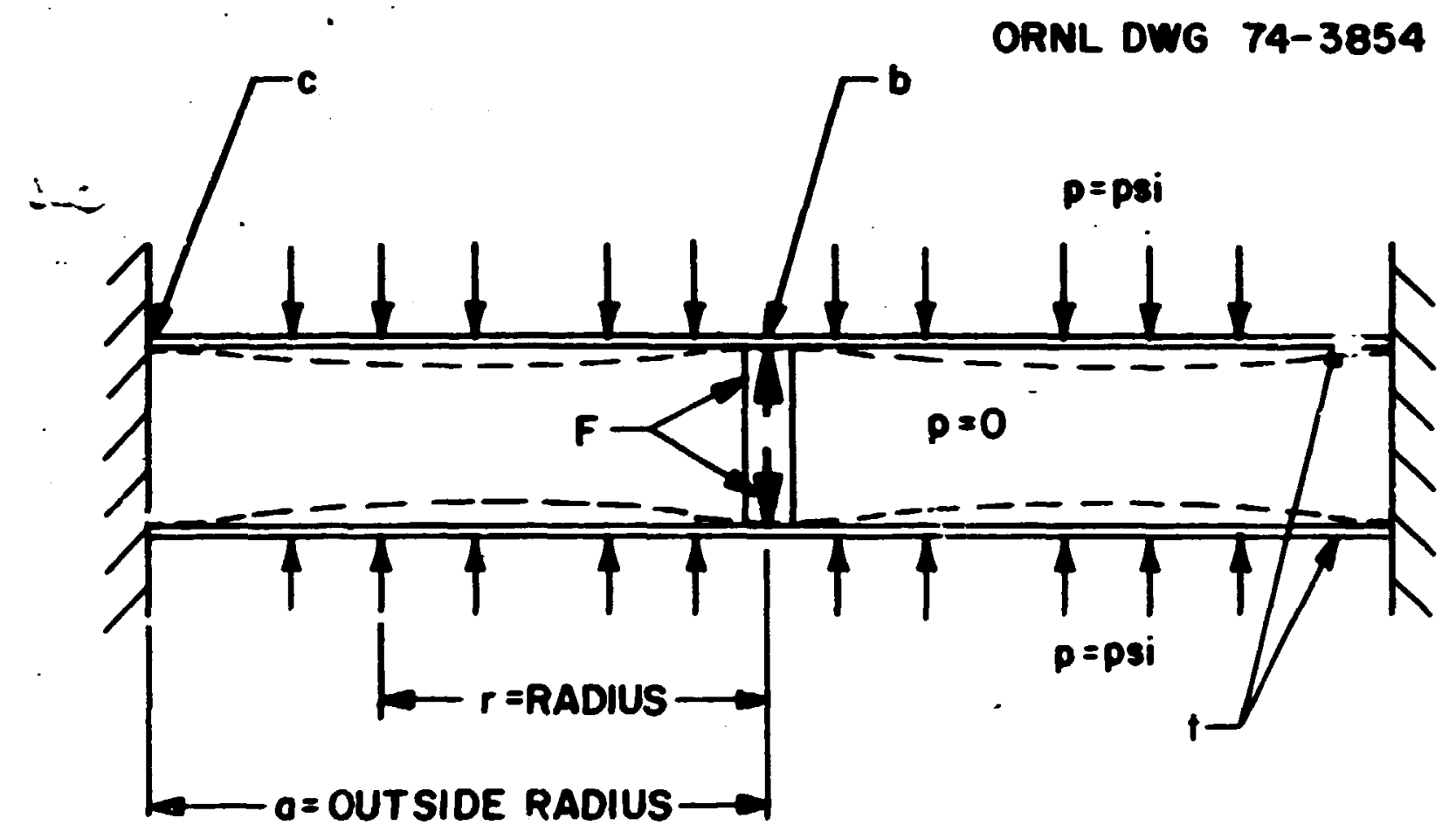

F1g. D.1. Calculatory model shield 1id. 
where

$$
\begin{aligned}
& \left.\sigma_{r P}=\left[(3 w) /\left(8 \pi t^{2}\right)\right]\left\{[3 a+1)\left(r^{2} / a^{2}\right)\right]-(a+1)\right\}, \\
& \sigma_{r P}=\left[(3 w) /\left(8 \pi t^{2}\right)\right]\{[(a+1) \ln (a / r)]-a\} .
\end{aligned}
$$

Thus

$$
\sigma_{r}=\left[\left(3 a^{2} p\right) /\left(8 n t^{2}\right)\right]\left\{\left[(3 a+1)\left(r^{2} / a^{2}\right)\right]-(2 a+1)+[(a+1) \ln (a / r)]\right\}
$$

In a sinflar fashion, the tangential stress, $\sigma_{T}$; 18

$$
\sigma_{T}=\left[\left(3 a^{2} P\right) /\left(8 n t^{2}\right)\right]\left\{\left[(a+3)\left(r^{2} / a^{2}\right)\right]-(n+2)+[(n+1) \ln (a / r)\}\right.
$$

\section{REFERẸNCE}

1. R. J. Roark, Formulas for Stress and Strain, 4th ed., McGraw-H111, New York, 1965. 


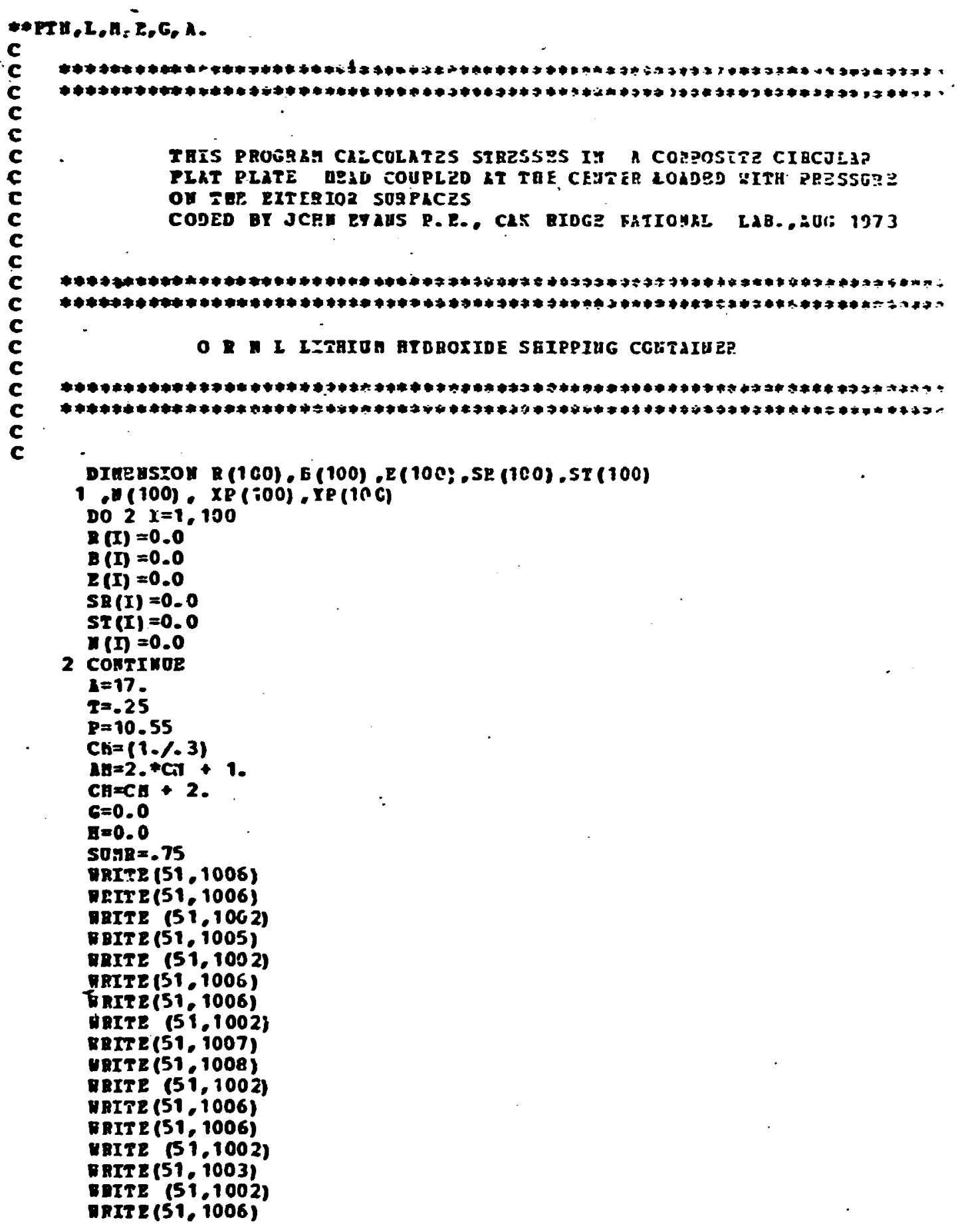




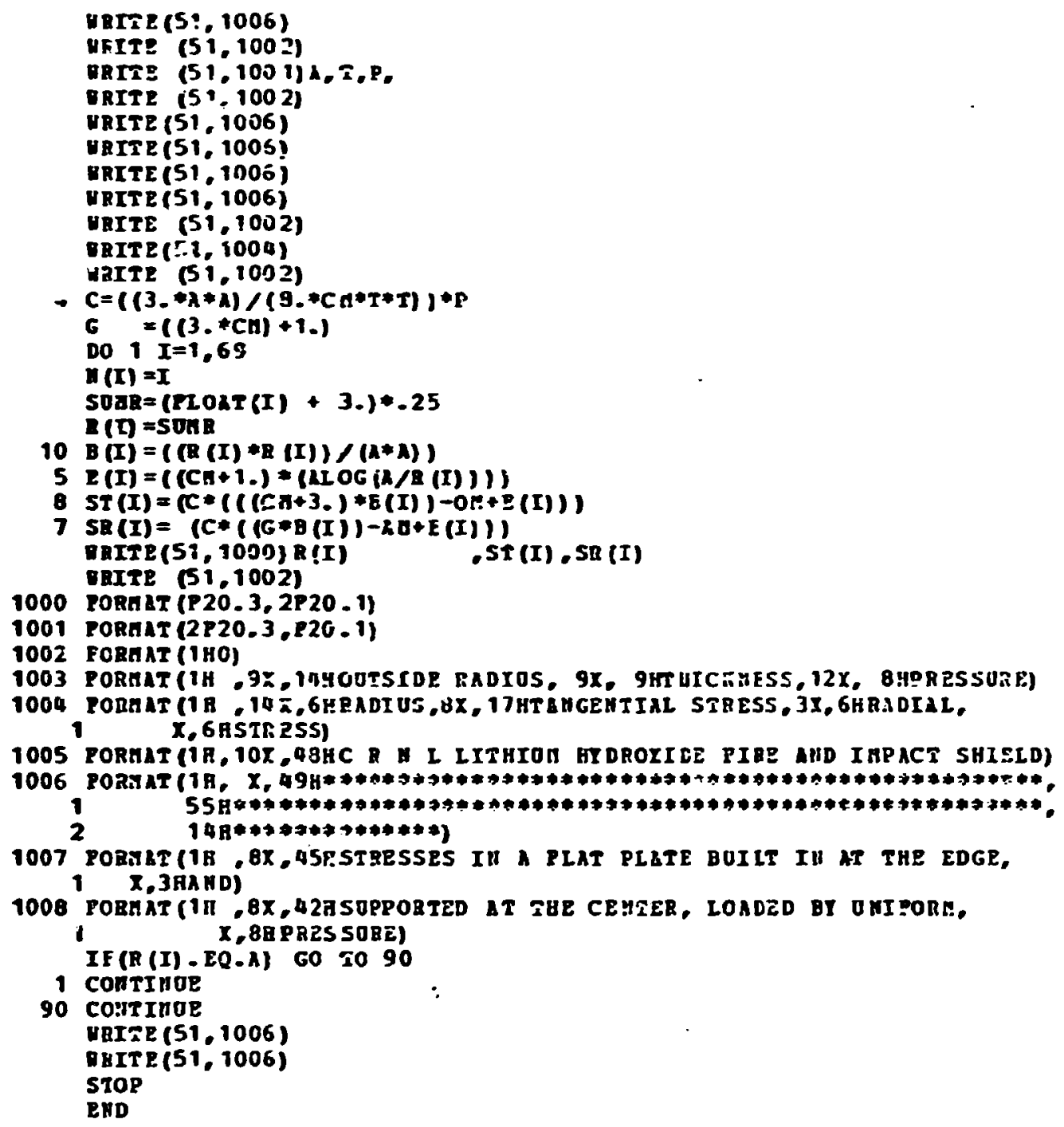





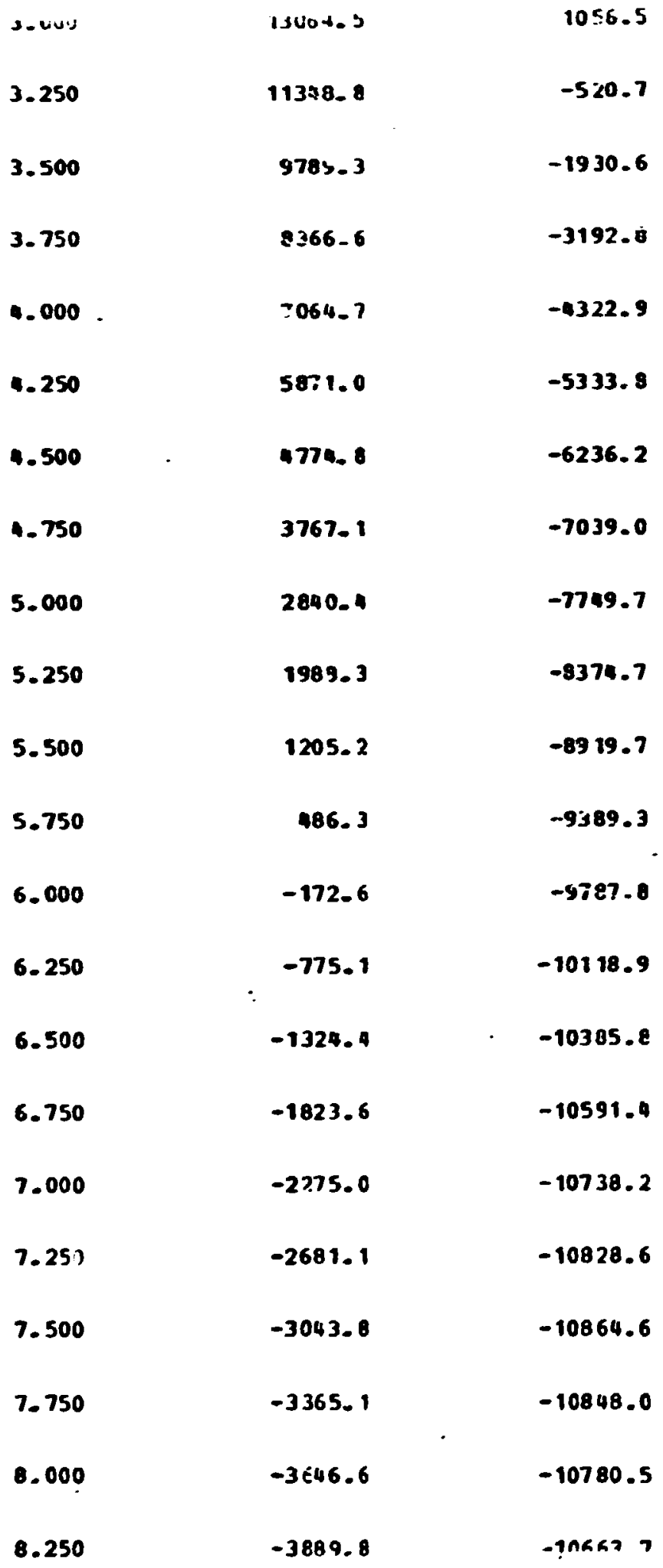




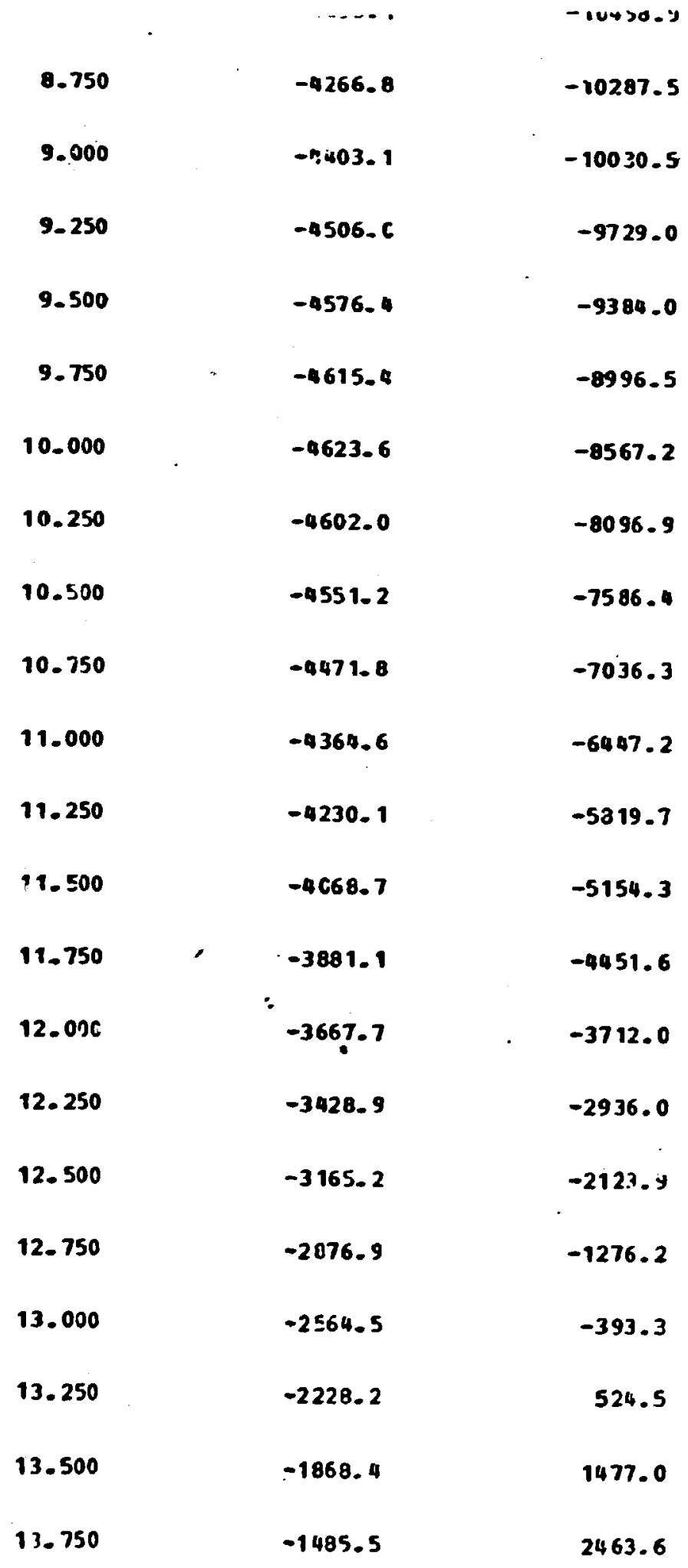




\begin{tabular}{|c|c|c|c|}
\hline - & 14.000 & -1013.0 & 3484.5 \\
\hline & 14.250 & -651.2 & 9538.6 \\
\hline & 14.500 & -200.3 & 5626.4 \\
\hline & 14.750 & 272.6 & 6747.4 \\
\hline & 15.000 & 767. & 7901.3 \\
\hline & 15.250 & 1283.9 & 9088.0 \\
\hline & 15.500 & 1821.7 & 10307.1 \\
\hline & 15.750 & 2380.8 & 11558.5 \\
\hline & 16.000 & 2961.0 & 12842.1 \\
\hline & 16.250 & 3561.9 & 14157.5 \\
\hline - & 16.500 & 0183.5 & 15504.7 \\
\hline & 16.750 & 4825.6 & 16883.5 \\
\hline & 17.000 & 5488.1 & 18293.7 \\
\hline
\end{tabular}

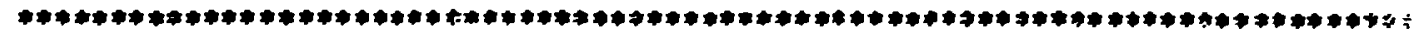

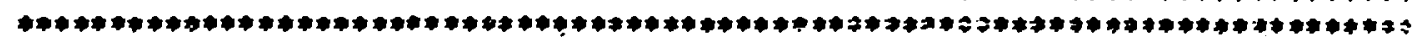


Hydrostatic Pressure Test of Composite Head

Test description

- On July 15, 1975, the lid of an ORWL 11thium hydroxide fire and Inpact shield was hydrostatically pressure tested in Building 3020 at ORIL. This particular lid had not been filled with the lithiun hydroxide material. The ild was placed on its edge and tied to supports as shown in Fig. D.2 (a). Dial Indicators were positioned at several points on the reinforced side of the lid. Pressure was Indicated by a gauge on the inlet. The results of this test are tabulated below.

Test results

Test No. 1

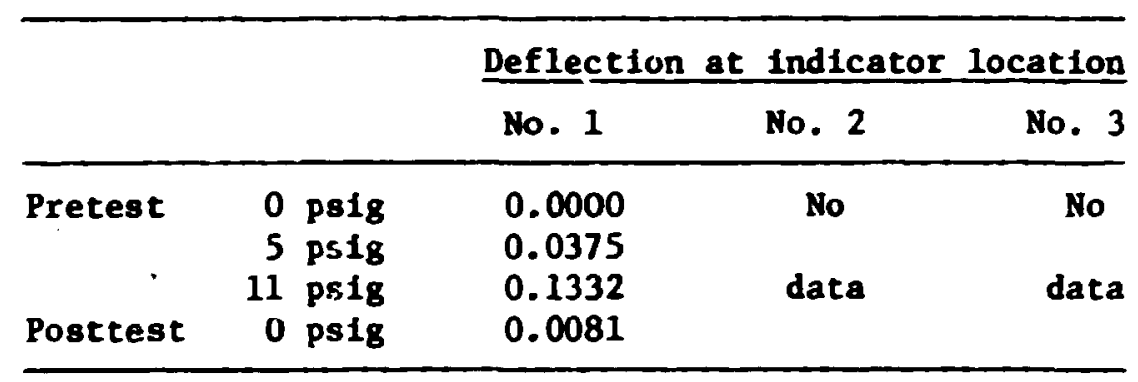

Test No. 2

\begin{tabular}{lrrrr}
\hline & & \multicolumn{3}{c}{ Deflection at indicator location } \\
\cline { 3 - 5 } & & No. 1 & No. 2 & No. 3 \\
\hline Pretest & 0 psig & 0.000 & 0.0000 & No \\
& 5 psig & 0.042 & 0.0155 & \\
Posttest & 11 psig & 0.144 & 0.0362 & data \\
\hline
\end{tabular}


ORNL DWG 75-12967
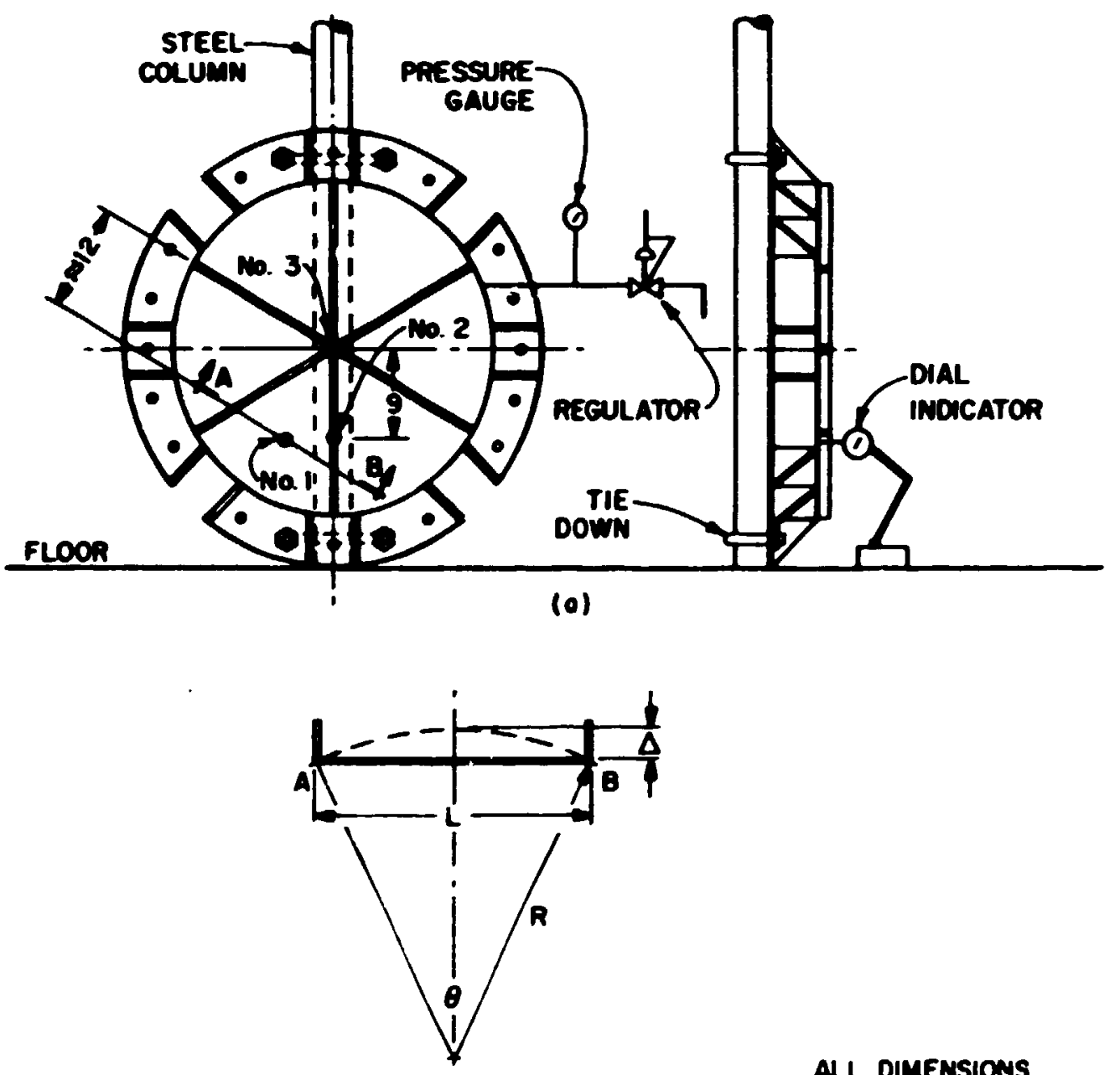

(b)

ALL DIMENSIONS GIVEN IN INCHES

Fig. D.2. Hydrostatic pressure test. 
Test No. 3

\begin{tabular}{lrrrrr}
\hline & & \multicolumn{3}{c}{ Deflection at indicator location } \\
\cline { 3 - 5 } & & No. 1 & No. 2 & No. 3 \\
\hline Pretest & 0 psig & No & No & 0.0000 \\
& 5 psig & & & 0.0018 \\
Postest & 11 psig & data & data & 0.0039 \\
\hline & 0 psig & & & & $0.0006^{-}$ \\
\hline
\end{tabular}

\section{Data reduction and calculations}

From the test results for test No. 2 at location 1, it can be seen that there was a $¥ 0.004-i n$. permanent deflection. The permanent strain or ser can be calculated by calculating the length of the element before and after pressurization.

The length of the element as shown in Fig. C.2 (b) before pressurization is

$$
L=2\left(12 / 3^{1 / 2}\right)=13.85640646 \mathrm{in} .
$$

Assuming the deflected curve is a portion of a circle, the deflected element will have a length equal to the arc length $\hat{A B}$. From the equations of a circle presented in the CRC Standard Math Tables, the arc is

$$
\hat{A B}=\mathbf{R} \boldsymbol{\theta},
$$

where

$$
\begin{aligned}
& \theta=2 \sin ^{-1} \frac{L}{2 R}, \\
& R=\frac{L^{2}}{8 \Delta}+\frac{\Delta}{2} ;
\end{aligned}
$$

therefore

$$
\widehat{A B}=13.85640925 \text { in. }
$$


The permanent elongation of this elenent is

$$
e=\widehat{A B}-L=0.00000279 \mathrm{in} .
$$

The permanent strain is

$$
e=e / L=2.01 \times 10^{-7} \mathrm{in} . / \mathrm{in} .
$$

This permanent strain is very small and indicates that the commonly accepted 0.27 offset yield point for stainless steel has not been exceeded. 


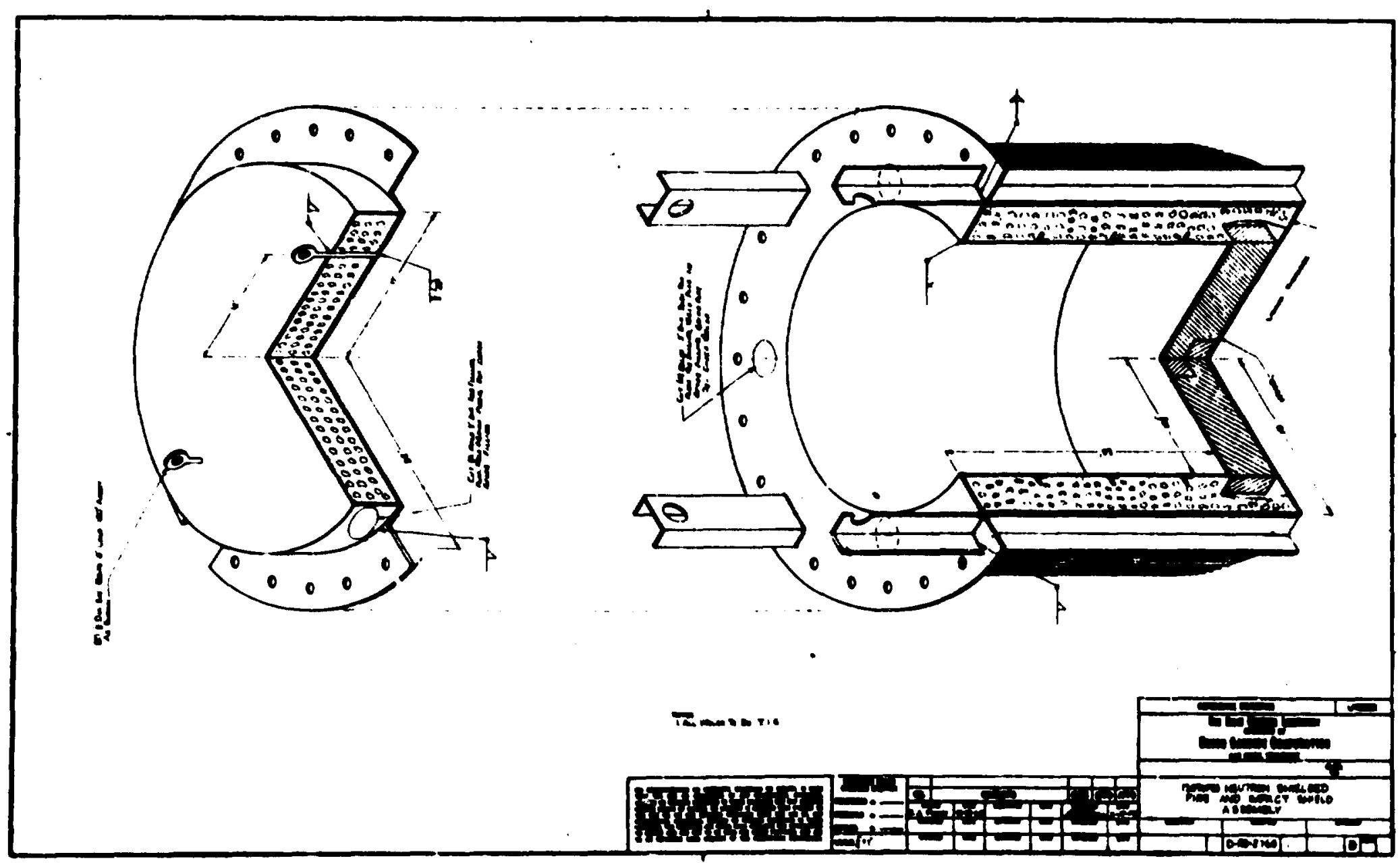

F18. E.1. Fabrication Drewing no. D-RD-2760. 


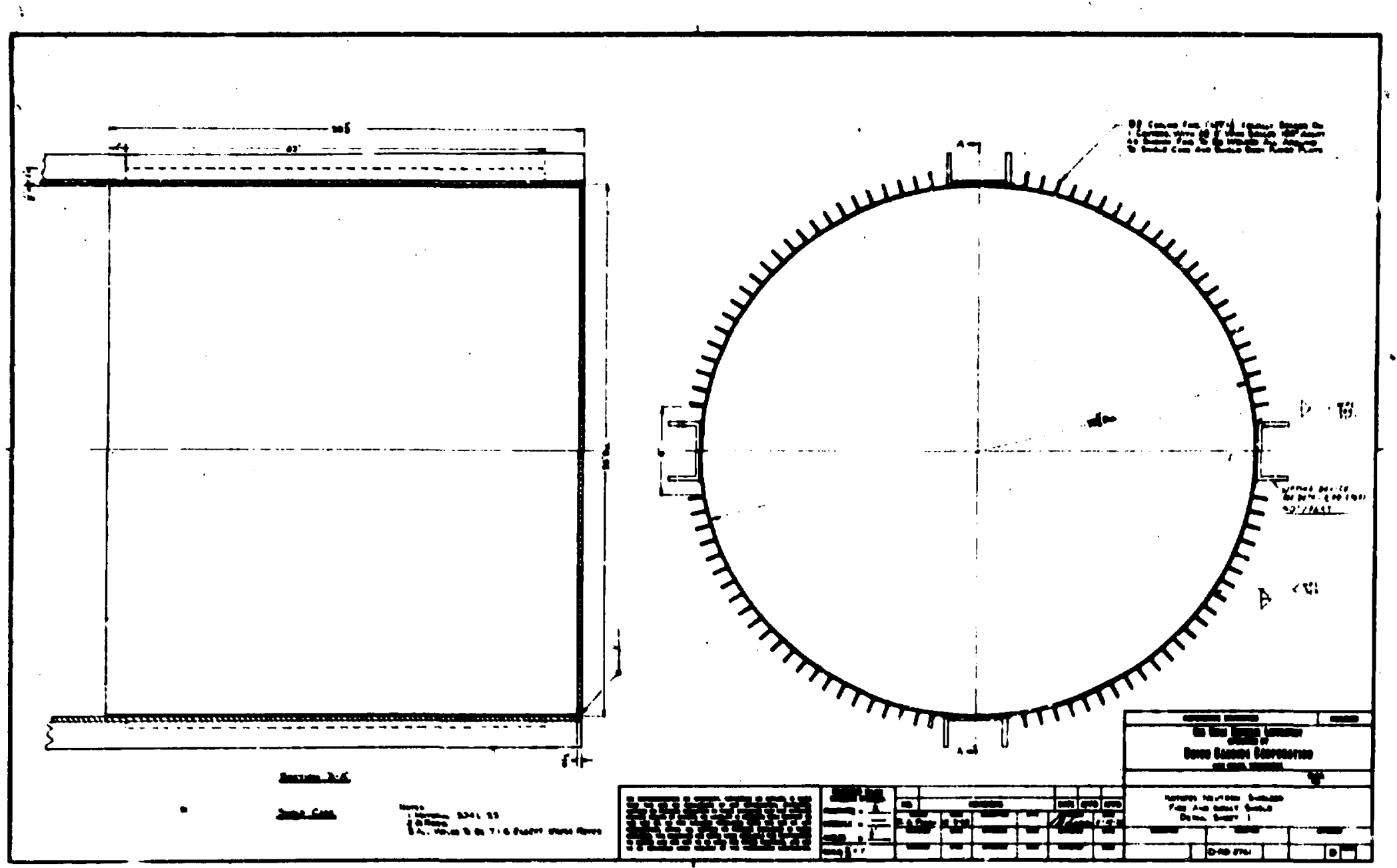

F1g. E.2. Fabrication drawing no. D-RD-2761. 


$$
=0
$$





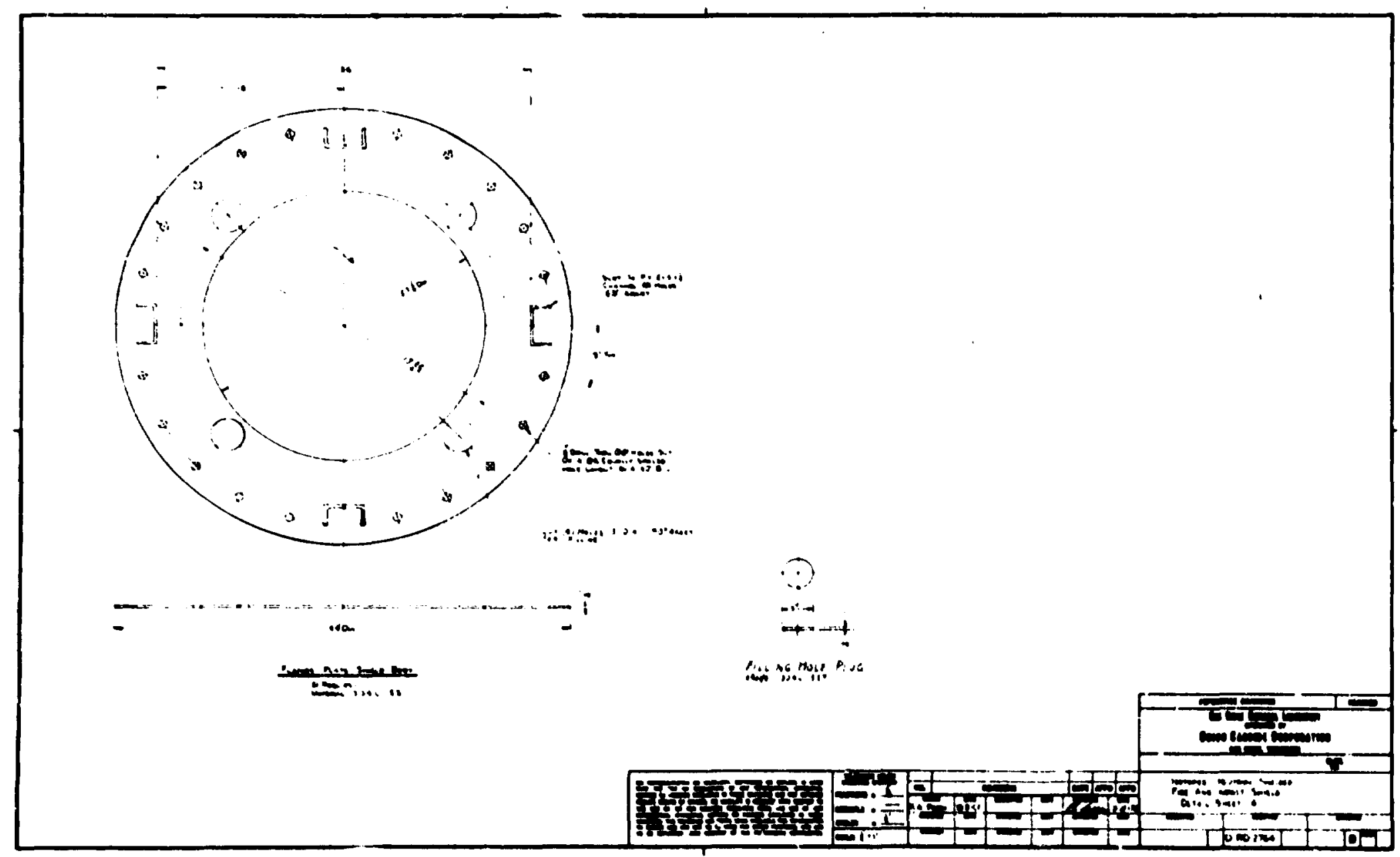

F1g. E.5. Fabrication drawing no. D-RD-2\%64. 
113

-

Appendix $\mathbf{F}$

MODEL TESTING PROCEDURE AND REPORT 
Impact Testing of the LiOH Shield Top

Energy Absorber Mortels

\section{$\underline{\text { Introduction }}$}

The tests described below were conducted to develop data from which the response of the ORIL lithium hydroxide shield in a top (with the axis of the shield vertical) inpaci of the shield on the unyielding surface could be calculated. The shield is detailed on ORN drawings M-11566-EY001-D through -003-D. The data taken were used to denonstrate that the cap (Part 2) remains secured to the body (vessel) (Part 1). The tests were performed by J. I. Evans and N. D. Bradley of ORNL and witnessed by R. E. Harris of AEC-ORO. The tests were condiscted at the ORNL drop tover on April 18, 1974.

The test model was a one-half scale nodel of one of the four channel sections extending above the container. It was intended that the channeis would buckie and protect the shield in a top impact. The model fabrication drawing is shown in Fig. F.1. Five models were fabricated in ORNL Shops in accordance with this drawing.

\section{Test procedure}

The variable-welght drop hammer was loaded to $121 \mathrm{lb}$. This is the half-scale equivalent of one-fourth the wet ght of the container. The test models were mounted one at a time on the lower surface of the variablewelght drop hamer, using four bolts. The length of each specimen was measured and recorded prior to dropping. A piezoelectric accelerometer was mounted on the hamer extension as described in ORNL/TH-1312, vol. 9. The daca acquisition system shown in $\mathrm{F} \mathrm{g}_{\mathrm{g}}$. F.2 was utilized to measure and record an acceleration with respect to time of each impact. The scope was set to make contact approximately $3 / 4 \mathrm{in}$. prior to the model contacting the 1mpact surface. The specimens were dropped from $30 \mathrm{ft}$ onto the unylelding ourfice, and the acceleration was measured, with respect to time, and recorded. The deformed length of the specimens was measured for all tests. 

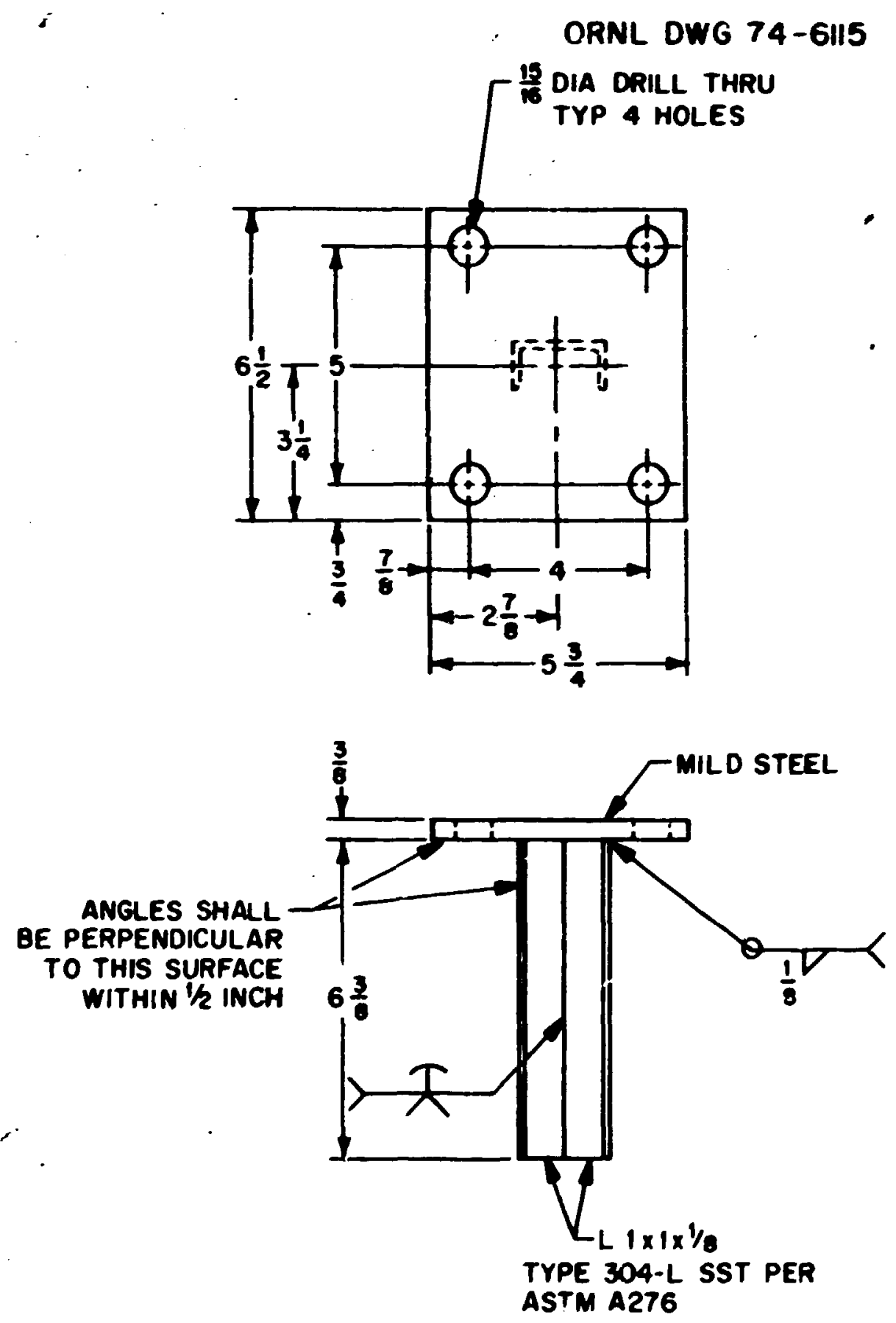

P18. F.1. Impact test model. 


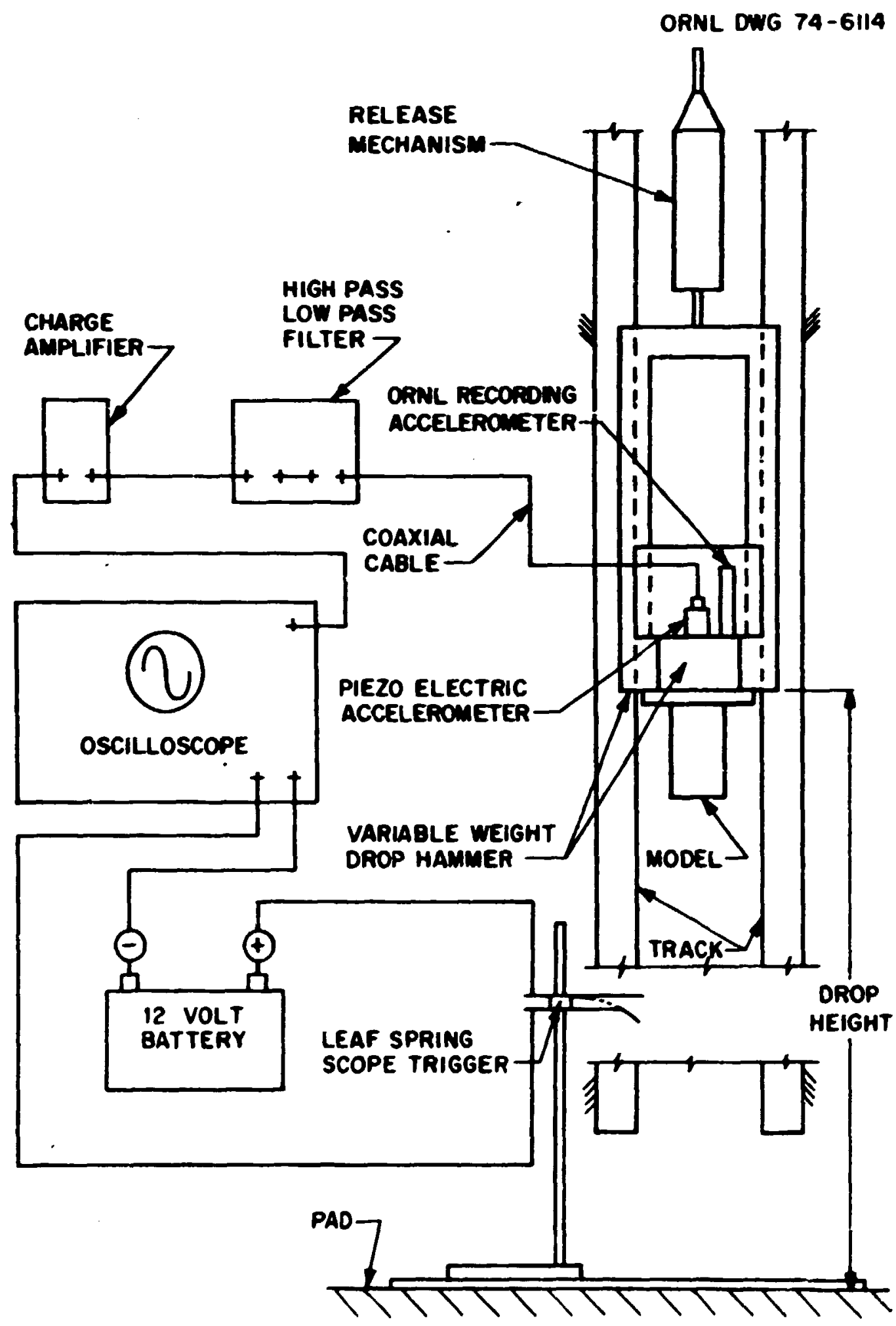

Ffo. F.2. Data acquisition systeá. 
Sumary of results and conclusion

The speciwens performed as expected and are adequate to absorb all the shield's energy. The results are sumarlzed In Table F.l. The specinens after testing are shown in Fig. F.3. Three of the specinens (74-1-1, 74-1-2, and 74-1-4) buckled and absorked energy as expected. The reaining two absorbed energy by a combination of buckling and rupture of the weld foining the two angle sections foraing the channel. It can be seen from Table F.1 that the difference in the response between specimens is not significant. It is therefore of little consequence which mode of deformation the specinen follows.

Toivic :... Impact data and results

\begin{tabular}{lcccc} 
Specinen & $\begin{array}{c}\text { Drop } \\
\text { height } \\
\text { (1n.) }\end{array}$ & $\begin{array}{c}\text { Weight } \\
\text { dropped } \\
\text { (1b) }\end{array}$ & $\begin{array}{c}\text { Final } \\
\text { deinrmation } \\
\text { (1L.) }\end{array}$ & $\begin{array}{c}\text { Maximua } \\
\text { Acceleration } \\
\text { (x 8) }\end{array}$ \\
\hline $74-1-1$ & 360 & 125 & 2.53 & 190 \\
$74-1-2$ & 360 & 125 & 2.36 & 200 \\
$74-1-3$ & 360 & 125 & 2.26 & 200 \\
$74-1-4$ & 360 & 125 & 2.53 & 200 \\
$74-1-5$ & 360 & 125 & 2.12 & 210 \\
\hline
\end{tabular}

arop height $\pm 1 / 2 \mathrm{in}$.

$b_{\text {Includes weight of specinen-mount Ing hardware. }}$ 


$$
\text { 1.5. } 35
$$


Appendix G

SHIELDING ANALYSIS 


\section{Radiation Safety Evaluztion of the ORR. Lithium}

Hydroxide Fire and Impact Shield

A study of the radiation safety of the ORML lithium hydroxide fire and impact shield was made using the ANISN ${ }^{2}$ discrete ordinates transport code and the 22-group neutron-18-group garma-coupled cross-section set. For purposes of this study, a source consisting of neutrons having an energy distribution of spontaneous fission neutrons from ${ }^{252} \mathrm{Cf}$ was used. No primary gana source was included, but secondary gama rays resulting . from neutron capture were included in the total dose rates obtained. A one-dimensional spherfcal annuli mock-up, using the radil of the cylindrical cask, was assumed, since such a representation should give doses as great or greater than those frow the real cylindrscal container.

The $\mathrm{LIOH} \cdot \mathrm{H}_{2} \mathrm{O}$ was assumed to be made up of $1007{ }^{7} \mathrm{Li}$ isotope. The undamaged shield contained a 4-1/4-in.-thick layer of LHOH $\cdot \mathrm{H}_{2} \mathrm{O}$ at a density of $0.031 \mathrm{lb} / \mathrm{in} .{ }^{3}$. The damaged shield, for which fire damage was assumed, contained dry LiOH with the same lithium density instead of the $\mathrm{LIOH} \cdot \mathrm{H}_{2} \mathrm{O}$ for the outer $1.6 \mathrm{in}$. of the 4-1/4-in. layer. Type 304L stainless steel was used for all wetal parts. Damage other than fire damage was not considered in this study.

The same strength neutron source was used for both the undamaged and damaged containers. The dose rates at the surface and at 3 ft from the surface of the shield were scaled to that source, yielding $200 \mathrm{millirems} / \mathrm{hr}$ at the surface of the undamaged shield. The results are given in Table G.1.

Table G.1. Dose rates from $L 10 H$ shield

\begin{tabular}{|c|c|c|c|c|}
\hline \multirow{2}{*}{ Condition } & \multicolumn{2}{|c|}{ At surface } & \multicolumn{2}{|c|}{3 ft from surface } \\
\hline & Total millirems/hr & 2 gama & Total milliremo/hr & 2 ganna \\
\hline Undamaged & 200 & 7.9 & 16.8 & 11.5 \\
\hline Damaged & 273 & 4.6 & 23.1 & 4.0 \\
\hline
\end{tabular}


The maximum contribution from secondary gaimma rays is 12.72 of the total dose rate, and the increase in the total dose rate due to fire damage both at the surface and at $3 \mathrm{ft}$ from the surface for the damaged shield is about 50\%. Since the allowable dose rate for a damiaged shield at $3 \mathrm{ft}$ from the surface is $1000 \mathrm{millifems} / \mathrm{hr}$ as compared with the calculated value of 23.1 milirems/hr, the shield satigfies the requirements for safety with a considerable margin for any uncertainties in the calculations.

\section{REFERENCE}

1. W. W. Engle, A User's Manual for ANISN, K-1693 (Mar. 30, 1967). 
Appendix H

CRITICALITY REVIEW 


\section{REQUEST FOR HUCLEAR SAFETY REYIEH}

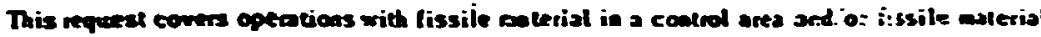
transfers that origiaste within the control ares. The control anea superviso: sisll complete We whots betor and describe the process andoe operations wo berfor-ex. eaphasiziag

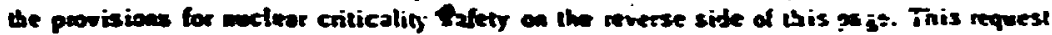
stll be arpowed by the Raduation Control Otficers of the originating D:ision and the Division(s) is which fissile asterial fill be crasterted.
O:ar

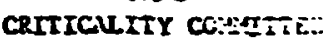

$\operatorname{LSR} 7371$

Commorionente Wazch, 1979

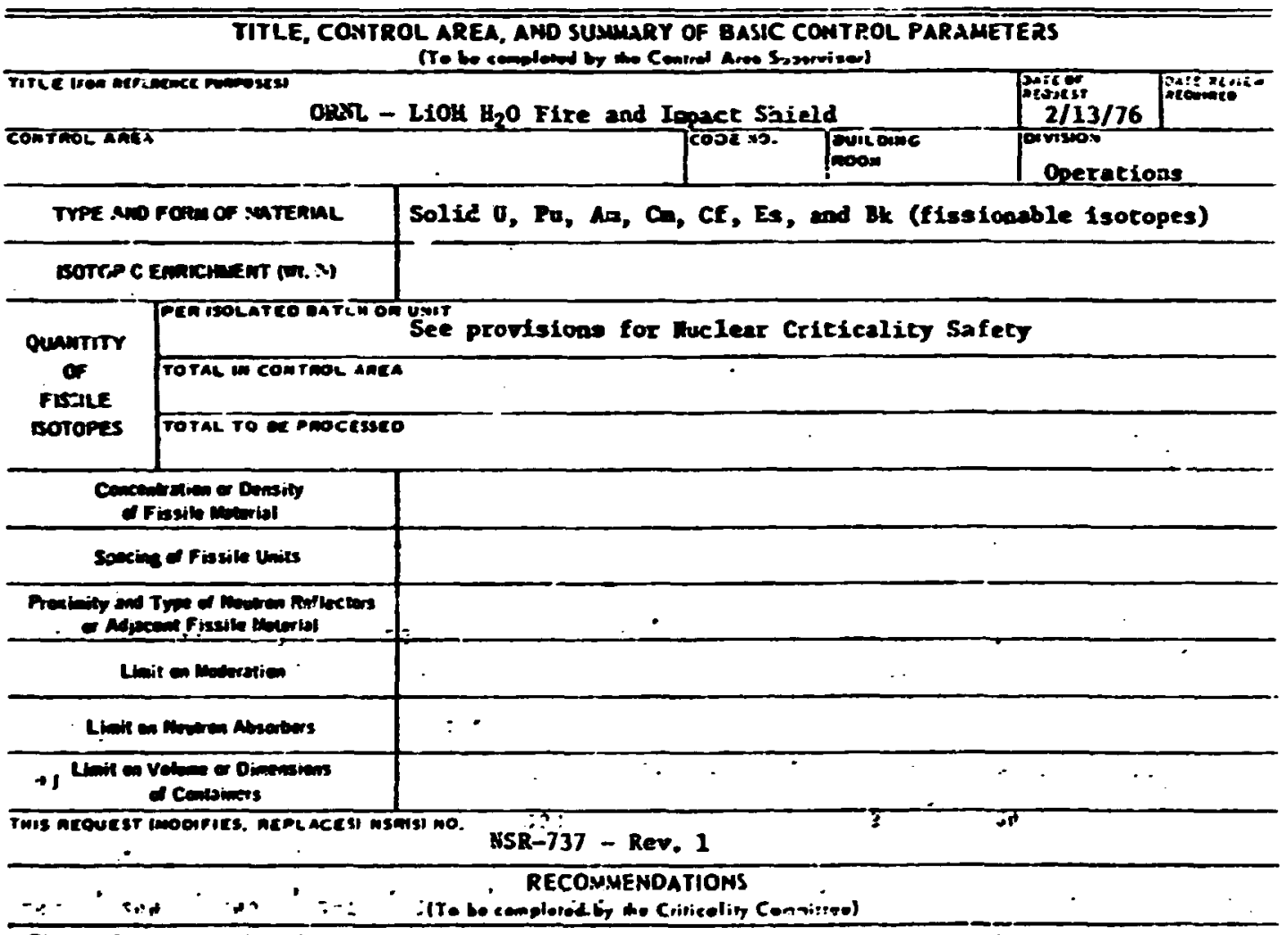

This endorsement is besed on mur present understending of the operation (iziztier sequired verbolly of in writing and is subject to review and cancellation.

This request is approved subjest to the requitcment that the sim of the even isotopes of Am, Bk, Zs and the odd 1 sotopes of $\mathrm{Cm}$, Cf, and Fa in the package not exceed $\mathrm{S}$ grans. In addicion, the maximum quancicy of ${ }^{233} \mathrm{U}, 235 \mathrm{U},{ }^{239}$ Pu plus ${ }^{241}$ pu s.hill not cxced 100 gi total. Thisis considered a safe mass assuaing refinction outside the packaze and water moderation inside the cavft?.

Other factors that help account for mclear safety are the configuration of the cask and cavity and normal dilution of the source with other neutron absorbing rpecies.

h11 shipeents will be issile class $x$.

$$
\text { E. } 0 \text { Re. }
$$




\section{1

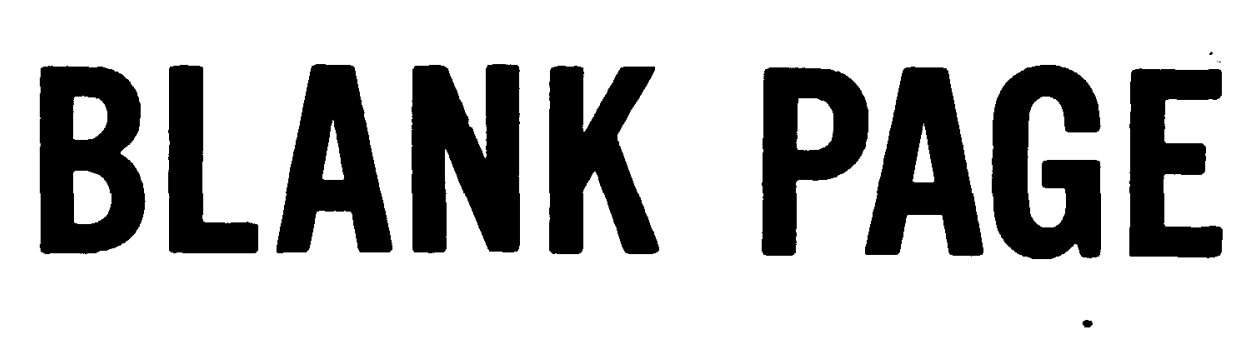

BLANK PAGE 


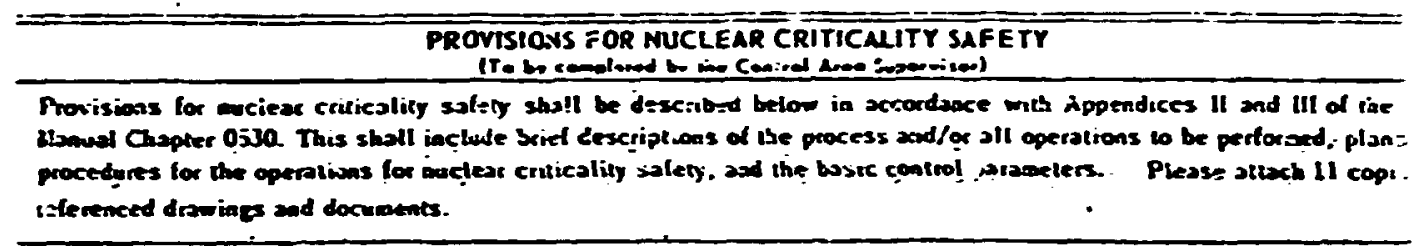

- The 0axt Iichiud Hydroxide Fire and Iepact Shield forcs'neutron shielding; hoirever, wien gaca shielding is required any Iype $n$ coatainer, or equivalent, is carried inside.

$\therefore$ The concerits of the coatainer will be any solid, large quantity radioactive ...

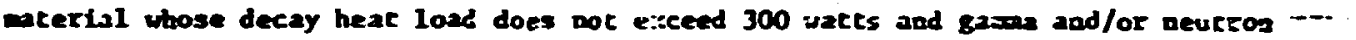

activity, that does not exceed allowable dose race levels. The eaxisa quanticy of. $242 \mathrm{~A},{ }^{244} \mathrm{C},{ }^{245} \mathrm{Cr},{ }^{247} \mathrm{Co},{ }^{249} \mathrm{CF}$, and ${ }^{251} \mathrm{Cf}$ will be 1 infted to a combined cotal of

5 grams. The concatoer will also be used co eranghort up co 150 grams of PuO 2 beat sources contalatins sreater thae $80 \mathrm{z}{ }^{236} \mathrm{Pu}$ and less than $162{ }^{239} \mathrm{Pu} ; 37{ }^{240} \mathrm{Pu}$ and 17 291 Pu and baving a decay heat laad of 200 watcs or less. The above caterlals will neet "spectal fors" requiresents.

The ask is incended for shiponts of up to 100 grats of fissionable materials Incleding $235 \mathrm{U},{ }^{233} \mathrm{U}$, and $239 \mathrm{Pu}$ in solid form.

\begin{tabular}{|c|c|c|c|}
\hline 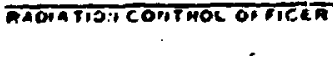 & prosion & 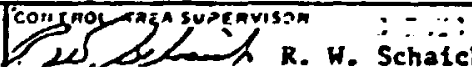 & $\begin{array}{l}\text { ou!t:oinc } \\
\therefore \\
\therefore\end{array}$ \\
\hline 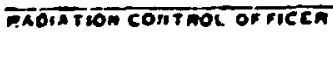 & forviston & 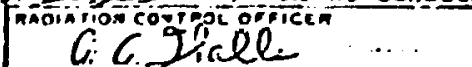 & Orision \\
\hline
\end{tabular}




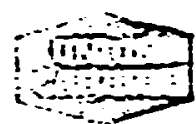

INTERNAL CORR:
PCST OFFICF HOX X OAK KIDEE, ITHENSSEE 31230 is $(::, m$ J. Hi. Viachect

(4.,...,.,.

i:s.:-

4500N

cest to File - RC
Des. Juiy 21, 1975

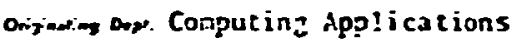

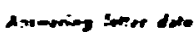

soling LiOH Cask

As $p=x$ your request, I have exanined the lioh cask for loadings fumished by you to establish validity of CLASS I desigmation.

In an effort to maxinize the calculated $k$ with the kE:O Honte Curlo code, the stcel external firc lioll shicid was ignored as was any intemal container configurations that may be used. The cask was described in the code as having a central cylindrical cariey with a radius of $31.3 \mathrm{~cm}$ and a height of $78 \mathrm{cn}$. The cavity was lined with $20.5 \mathrm{~cm}$-thick layer of 30455 . A $11.43 \mathrm{ca}$-thickness of Lioti cotered tice top and lateral surfices of the stainless sieel while the bottom surface had a $1.9 \mathrm{~cm}$-thickness of plyiood. The fissionable aaterials were considered as spliercs centered in the cavity. The calculated b, valucs are slemarized in the following table.

\begin{tabular}{|c|c|c|c|}
\hline $\begin{array}{l}\text { Fissionable } \\
\text { Haterial }\end{array}$ & $\begin{array}{c}\text { Density } \\
\text { g/cc }\end{array}$ & $\begin{array}{c}\text { Hass } \\
8\end{array}$ & $\underset{k_{\infty}}{C a l c u l a t e d}$ \\
\hline 2350 & 18.7 & 100 & 0.14 \\
\hline $233 \mathrm{U}$ & 18.4 & 100 & 0.20 \\
\hline $239 \mathrm{Pd}$ & 19.7 & 100 & 0.23 \\
\hline $230^{\circ}$ Pro, & 10.6 & 150 & 0.21 \\
\hline $2{ }^{4 h} \mathrm{Ca}_{4}$ & 13.5 & 5 & 0.03 \\
\hline
\end{tabular}

It would appear that these mass linit; would comprise satisfactory va incs to permit use of the cask as a Class I container.

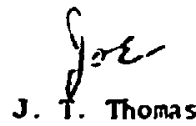



$6 / 2175$

DEPLETED LITHILS-6 INDEOXIDE, MO:DHVRTtE

FOS HYL LIOH FIRE AVI T:PACT SUIELD

Laborator analyses are on a nacerial basis.

Laboratory Req Gieton Ko. 821046 -

Aton $\%{ }^{7_{\mathrm{LS}}} \quad 97.52$

Acos $76_{\mathrm{LI}} \quad 2.48$

Ut. $7^{7}$ L1 97.87

Uc. $7^{S_{L 1}} \quad 2.13$

Cos - LI/Cas of Material

7 LiOA

$\mathrm{Z}_{2} \mathrm{O}$

0.166039

$7 \mathrm{CO}_{2}$

56.965

$2 \mathrm{Cl}$

42.11

0.17

0.0053

PPA

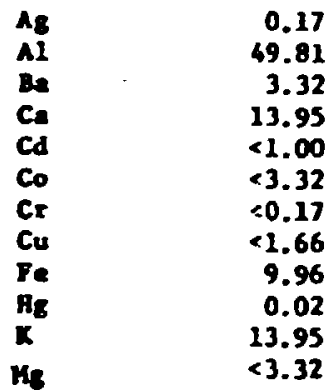

PPI

$\begin{array}{lr}\text { Hn } & <0.17 \\ \text { Ho } & <0.66 \\ \mathrm{Ha} & 13.95 \\ \mathrm{Hb} & <3.32 \\ \mathrm{Hi} & <1.66 \\ \mathrm{~Pb} & <0.66 \\ \mathrm{SI} & <3.32 \\ \mathrm{Sn} & <3.32 \\ \mathrm{Sr} & <1.66 \\ \mathrm{~V} & <1.66 \\ \mathrm{U} & <16.60 \\ \mathrm{Zn} & 0.19\end{array}$




\title{
INTRA-LABORATORY CORRESPONDENCE
}

\author{
oAX Roce mational LaBORatogr
}

To:

R. U. Schateh

Date: February 26, 1975

ce: R. E. Stzenore

Subjeet: $x-111507$ LiOH SUGARMN FIRE SHIETD

The presaure cest was conpleted on chis Fire Shitid and Lid on this dace.

Pressure - 2 pels

Soap Solution - Sherlock Gas and Air Leak Detector Type I

Eo visible leaks rere detected on Fire Shield body or Iid.

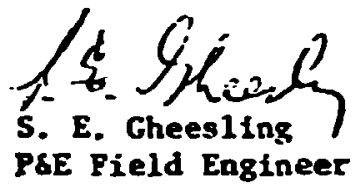

SEG: RES: drT 


\section{INTRA-LABORATORY CORRESPONDENCE}

OAK RIOGE NATIONAL LABORATORY

To:

R. H. Schaich

Dace: June 17, 1975

Subject: LIOH FIRE SHIELD LID VOLLi:T.

Filled an empty LiOH Fire Shield lid with vater.

Yoid space in the lid took 61.150 liters.

$$
\begin{aligned}
& 61.150 \div 3.785=16.156 \text { gallons } \\
& 16.156 \times 231=3732.036 \mathrm{cu} . \text { in. }
\end{aligned}
$$

Used 107 pounds of LiOll to fill a siailar lid.

Used 8.92 pounds of water to give the 1:10 ratio.

$115.92+3732=0.031$ pounds/cu. In.

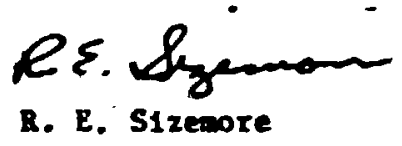

RES : dr: 


\section{INTRA.LABORATORY CORRESPONDENCE}

CAK RIDGE NATIDHAL LABORATORT

To:

B. P. Schaich

Dace: June 12, 1975

Fron: R. E. Sizenore

ce: S. E. Cheesling

Subject: LIOH FIRE SHIELO FUSIBLE PLUCS

Beat tests vere conducted on two of the LiOH fire shield fusfble plugs.

The first plug was subjected to $100^{\circ} \mathrm{C}$ for $2-1 / 2$ hr with the following results:

Starting length of fusible section - $0.782 \mathrm{In}$.

At the end of the heating cycle there was 0.287 in. of the

fusible material still in the plug.

The second plug was subjected to $110^{\circ} \mathrm{C}$ for $2-1 / 2 \mathrm{hr}$ with the following results:

Starting length of fusible section - 0.782 in.

At the end of the heating cycle there was $0.130 \mathrm{in}$. of the

fusible aterial still in the plug.

Both tests were conducted in our drying oven. The plugs vere suspended in a glass beaker. No pressure was applied to the plugs.

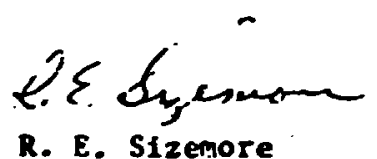

RES : drw 


\section{INTRA-I ABDRATOR'Y CORRESPONDERICE SAK FIOAF MATIC.NAL LASORATORY}

May 9, 1974

TO: - Johe H. Evans

SHBJECT: Inspecticn of ORII. Isotopes FIre and Impact Shteid tieldacncs.

OndL Dradings:- H11566-5y-001; -00z \&-003

Five weldents (Property No., $x-111506, x-111507, x-111508, x-111509$ and $x-111510)$ were visually tnspected for qualtey vorkanship and general coaformance to the referenced drawings. All welds appear to be of good quallty and seen to be of the type joints as specified on the drawings. The support channels and soze of the sheet etal used in fabrication bore Ideaclfication markings as beizg 304L Stainless steel.

Identiflcation Plates have not beed attached to these f̈abrications. Property numbers have been atcacined to the botisz of each weldnent.

This inspection indicates good quality workmsnship aad, in our opiaton, no reason to question the integrity of the weldaent.

DUSPECTIDA ENGLAEERING DEPT. 
Appendix J

THERYAL STUDY OP LIOH

(Memo from R. J. Lauer to R. D. Seagren) 


\section{INTRA LABORATORY CORRESPONDFNCE.}

OAX BIDIE NiTIGIAL LA.COKATORY

June 27,1959

To: R. D. Sergren

Subject: ISnthly Report for June, 1959

\section{Therral Study of LiOH}

The therwal study continued with the collection of data while the haater power was increased in 10-watt increments fron 50 watts to a maximum of 100 wats. As reported in liay, 1969, the LiOf block lost weight at a rate of 3 lbs./day as the water was driven off. This was the maxinus rate until $-27 \%$ of the weight had been lost. The rate eradually decreased until all the water, wich coreprised 12.77 , of the tojal isight, had bien lost. The weter driven off is ettributed to $\sim 2 \%$ free moisture and the rest is rater of hydration. Sore refluring of the water was apparent i.c. water was being driven from the center of the bial block to the outer surface, which was wrappad in a polycthylcne bag, where the lower temperature induced condensation. The condensate was then ebsorbed by the LiOt thus complcting the reflux cycle. This reflux cycle was apparent until $40 \%$ of the weight was lost.

One objective of this study was to calculate a value of the thermal conductivity $(K)$ for $\mathrm{LiO}$ l at various rates of heat flow $\left(q_{k}\right)$ by conduction through the LiOH. Data collected for the range of 50 to 90 wa'ts did not "give satisfactory results i.e. is c unsistent values for $K$ and $\Delta T$. The probable reason is the reflwxing or the water through the LioH. The data collected will be cher:ed eqcin, and a different approach in use of the data to calculate $K$ will be attempied. A rore satisfactory result was achicved horiever for data collected with the heater power set at 100 watts. In calculating the thermal corductivity $K$ the rate of heat mow 1 s defined by the equation

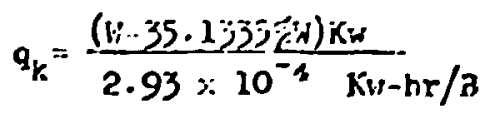


where -35 \% of the heat iss lost through piths othier thin tine instrimented path over vhich the data ias veing collected, and $\forall$ is tha heater fower in kilowetis. The value of k kizs detined by the equation

$$
K=\frac{q_{i}^{-}\left(r_{0}^{\left.-r_{i}\right)}\right.}{\Delta T \bar{A}}=B t u / h r-{ }^{-} F-r_{i}
$$

where $\left(r_{0}-r_{i}\right)$ is the diriference of the LiOA cylinder radil, $\Delta T$ is th: temperature drop across the radial difference, and $\bar{A}$ is the $3 c_{3}$ arithmic mean of the surface area where $A=2 \pi r l$. Table $I$ lists some of the pertinent datz with the heat.er at 100 watts, and $K$ vs. \& water by wt in LiOI is plottaù in eraph l'o. 1 . A second study is now uncer way to collect data to deternins a value of $K$ for the drs cylinger of Lio:I. The data collected for the heater set at 80 through 100 ratts in 10 ratt increments is listed in table II: This study will continue through July, lóg.

\section{$\underline{X-R a y ~ U n i t ~}$}

The Faxitron $x-r z y$ and fluoroscope unit purchased by the Isotopes Engineering Group has been delivered and is being installed in Bldg. 3026-c.

\section{Capsuze Puncturing Apparotus}

The parts of the puncturing epparatus, which were being machined, have been finish:-and rinal assembly of the apparitus should be conpleted within the next two weeks. As sonn as the assembly and testing of the apparatus has been done, cell space and time will be scheduled, and an attempt will be mede to get a gas sample and other required data concerning the oulged source capsules.

\section{$\mathrm{Kr}-85$ Lsak Test}

The 3 capsules to be used in determining a leak rate correlation between lle and $\mathrm{Kr}-85$ have becn checked with He. Tro of the capsules still have leaks two large to be accuratcly rated on the lle leak 
tester. An attrigt will afin be to peen the lerk holes to decrive the lcal size.

Table I. Dria used to deisernine value of $k$ with heater poiner at loj watts and to plot $i$ vs. Fisater Jost.

\begin{tabular}{|c|c|c|c|}
\hline $\begin{array}{l}\Delta \mathbf{T} \\
{ }^{\circ} \mathbf{F}\end{array}$ & $\begin{array}{l}\text { Sint. } \\
\text { Ius. }\end{array}$ & $\begin{array}{c}\text { of water by wt. } \\
\text { in LiOA } \\
\end{array}$ & $\stackrel{K}{\text { Btu/inr- } F-r t}$ \\
\hline $\begin{array}{l}285.8 \\
327.2 \\
332.6 \\
343.4 \\
347.0 \\
350.6\end{array}$ & $\begin{array}{l}23.0 \\
25.7 \\
32.1 \\
33.3 \\
1,4.3 \\
48.5\end{array}$ & $\begin{array}{r}21.77 \\
20.01 \\
114.20 \\
4.23 \\
3.70 \\
0.00\end{array}$ & $\begin{array}{l}0.316 \\
0.276 \\
0.272 \\
0.263 \\
0.261 \\
0.2576\end{array}$ \\
\hline
\end{tabular}

Table II. Data used to datermine value of $\mathbf{K}$ for dry Lior while varying heater power l.e. $q_{k}$.

\begin{tabular}{r}
$\begin{array}{r}\text { Heater Power } \\
\mathrm{kw}\end{array}$ \\
\hline $80 \times 10^{-3}$ \\
$90 \times 10^{-3}$ \\
$100 \times 10^{-3}$
\end{tabular}

$$
\stackrel{\Delta T}{F}
$$$$
295.6
$$

334.7

350.6
$\mathbf{K}$

$$
\text { Biu/hr- }
$$$$
0.24393
$$

$0.21+310$

0.25760

R. J. Jauer 


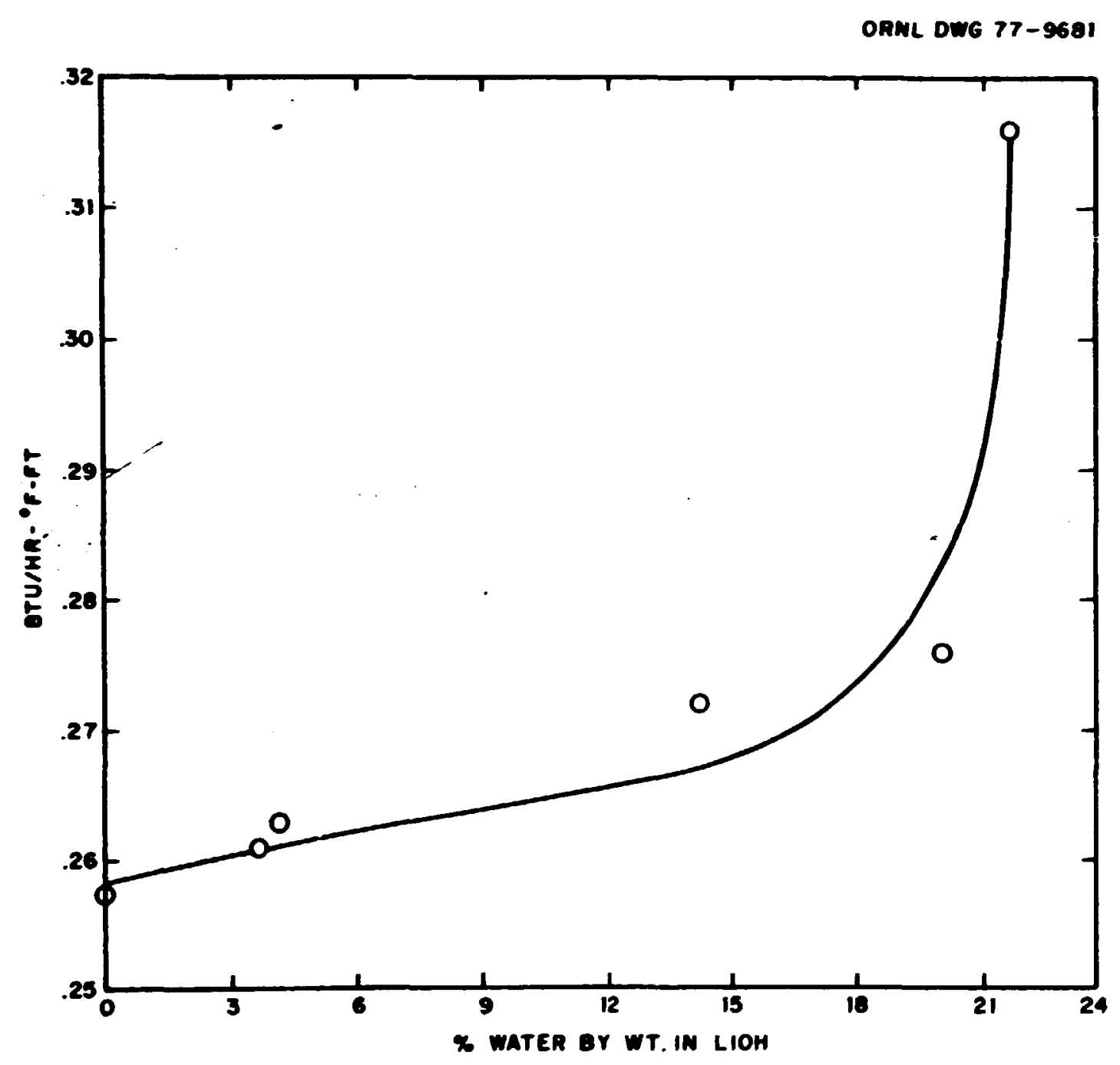

